\title{
6. PETROLOGY OF IGNEOUS ROCKS AT MIDDLE VALLEY, JUAN DE FUCA RIDGE ${ }^{1}$
}

\author{
Debra S. Stakes ${ }^{2}$ and James M. Franklin ${ }^{3}$
}

\begin{abstract}
Leg 139 of the Ocean Drilling Program drilled igneous rock at four sites in Middle Valley: Site 855 from the eastern boundary fault of the valley; Site 856 from late mafic sills that crosscut a major sulfide deposit; Site 857 from a series of highly altered sills of variable chemistry; and Site 858 from a topographic high beneath an active site of hydrothermal discharge. The oldest rocks are from Site 855 . These are N-MORBs containing refractory megacrysts of olivine, calcic plagioclase and $\mathrm{Cr}$-rich clinopyroxene. The rocks have $[\mathrm{La} / \mathrm{Ce}]_{\mathrm{n}}=0.76-0.82$, and $[\mathrm{Ce} / \mathrm{Yb}]_{n}=0.76-0.89$. Igneous rocks from Site 856 are relatively fresh (but more altered than those from Site 855) young sills that postdate the main phase of axial magmatism and associated hydrothermal alteration. These are some of the most primitive compositions from the northern Juan de Fuca Ridge and contain refractory megacrysts of olivine and chromian spinel, with plagioclase of intermediate compositions (slightly more sodic than those for Site 855). The rock compositions are strongly depleted in LREE, with $[\mathrm{La} / \mathrm{Sm}]_{n}=0.28-0.29$ and $[\mathrm{Ce} / \mathrm{Yb}]_{n}=0.37-0.39$. Samples from the chilled contacts with sediments have spurious trace element chemistry due to alteration. A topographic high drilled at Site 858 is composed of N-MORB and T-MORB lavas that must have erupted above the sediments, suggesting a relatively old age, near that of the basement. They are aphyric to slightly phyric with sodic plagioclase and magnesiochromite. Pseudomorphs of small mafic phenocrysts are inferred to be replacements of olivine. These rocks are relatively homogeneous with $[\mathrm{Ce} / \mathrm{Yb}]_{\mathrm{n}}>1.3$, suggesting a lower percentage of partial melting compared to the other sites. They have $[\mathrm{La} / \mathrm{Ce}]_{\mathrm{n}}=0.84-0.94$ and a variably developed negative Eu anomaly. The sill complex drilled at Site 857 is extensively altered. Trace elements (especially REE) suggest that they are derived from heterogeneous mantle source regions, with some mixing. One source region is similar to that of Site $855 \mathrm{with}[\mathrm{La} / \mathrm{Ce}]_{n}$ $<0.82$ and $[\mathrm{La} / \mathrm{Yb}]_{\mathrm{n}}<1$. The second source is similar to that of Site 858 with $[\mathrm{La} / \mathrm{Ce}]_{\mathrm{n}}>0.82$ and $[\mathrm{La} / \mathrm{Yb}]_{\mathrm{n}}>1$. Although the age relationships among the sills are difficult to constrain, the former compositions tend to be the most altered, and likely of greater age. Thus the tectonic scenario is that a robust magma chamber formed the Site 855 basalts and fed the older sills at Site 857 . Magmas constructed the Site 858 topographic high and basalts from a similar mantle source region fed some of the sills at Site 857. Sills of intermediate composition suggest mixing between these magmas, either in the source region or in crustal magma chambers. The Site 856 sills postdate the ridge jump to West Valley after the Middle Valley rift failed.
\end{abstract}

\section{INTRODUCTION}

The Middle Valley segment at the northern end of the Juan de Fuca Ridge is a deep extensional rift blanketed with $200-500$ meters of Pleistocene turbiditic sediment. This area was selected to be drilled during Ocean Drilling Program Leg 139 to elucidate the processes and products of hydrothermal circulation in a sedimented ridge environment (Davis, Mottl, Fisher, et al., 1992). Although Middle Valley is hydrothermally active (there are hot springs and regions of high heat flow), a relatively continuous impermeable sediment cover over zero-age crust limits the recharge and discharge of hydrothermal fluid (Davis and Villinger, 1992). This sedimentary cover also obscures the volcanic morphology and possible relationship between hydrothermal activity and specific magmatic events. More fundamental is the impact and interaction of the sediment cover on the structure and lithology of the volcanic units, transforming what would be the shallow volcanic carapace of an unsedimented ridge into a series of crystalline sills intruded into the water-rich terrigenous sediments.

During this leg, holes were successfully drilled at four sites: (1) Site 855 , near the eastern boundary fault; (2) Site 856, a topographic high with massive sulfide deposits; and a central area with (3) Site 857 , high heat flow, and (4) Site 858, active hot springs (Davis, Mottl, Fisher, et al., 1992) (Fig. 1). The latter two sites are reentry sites and form a suite of drilled samples from an active spreading center hydrothermal zone. This paper describes the petrology of igneous rocks from these four sites. At Site 855, only a few samples of MORB-type basalt, thought to represent the basement to Middle Valley during its

\footnotetext{
${ }^{1}$ Mottl, M.J., Davis, E.E., Fisher, A.T., and Slack, J.F. (Eds.), 1994. Proc. ODP, Sci. Results, 139: College Station, TX (Ocean Drilling Program).

${ }^{2}$ Monterey Bay Aquarium Research Institute, 160 Central Avenue, Pacific Grove, CA 93950, U.S.A.

${ }^{3}$ Geological Survey of Canada, 601 Booth Street, Ottawa, K1AOE8, Canada.
}

early rifting stages, were obtained. Site 856 has a few thin sills of primitive picritic basalt. Site 857 intersected numerous mafic sills. At Site 858 , a constructional high built of moderately evolved basalt and basaltic andesitic was discovered beneath $250 \mathrm{~m}$ of altered sediments at the area of high-temperature active venting. Samples from each of these four suites are thus treated separately in the present report with the mineralogical data presented first, followed by chemical data. Although a detailed description of the hydrothermal alteration is not provided here (Stakes, unpubl. data), a summary of the relative impact of alteration on whole-rock chemical variation is provide for each site. The results of this study demonstrate the nature of primary magmatic variation in a ridge setting, where mafic sill complexes make up much of the volcanic stratigraphy and younger seamounts or primitive magmas provide evidence of variable melting conditions beneath a rift with waning magmatic activity.

\section{ANALYTICAL METHODS}

\section{Mineral Chemistry and Petrography}

The results presented here are based on detailed petrographic examination of over 200 polished thin sections followed by detailed electron microprobe studies. Microprobe facilities at the University of South Carolina (silicates, spinels) and the Geological Survey of Canada (sulfides, iron oxides) were used. Instruments at both institutions are fully automated Cameca SX-50 electron microprobe systems with on-line mineral formula calculations based on stoichiometry (spinel, plagioclase, olivine). All phases were analyzed with a focused beam (2-3 microns beam size), $15 \mathrm{kV}$ accelerating voltage and ZAF on line correction. A minimum of four analyses was obtained for each grain including multiple analyses of cores and rims to determine zonation. Pyroxene formulas were calculated using the algorithms of Papike et al. (1974). A combination of artificial and mineral standards are used by each facility. Results of microprobe analyses are presented in Table 


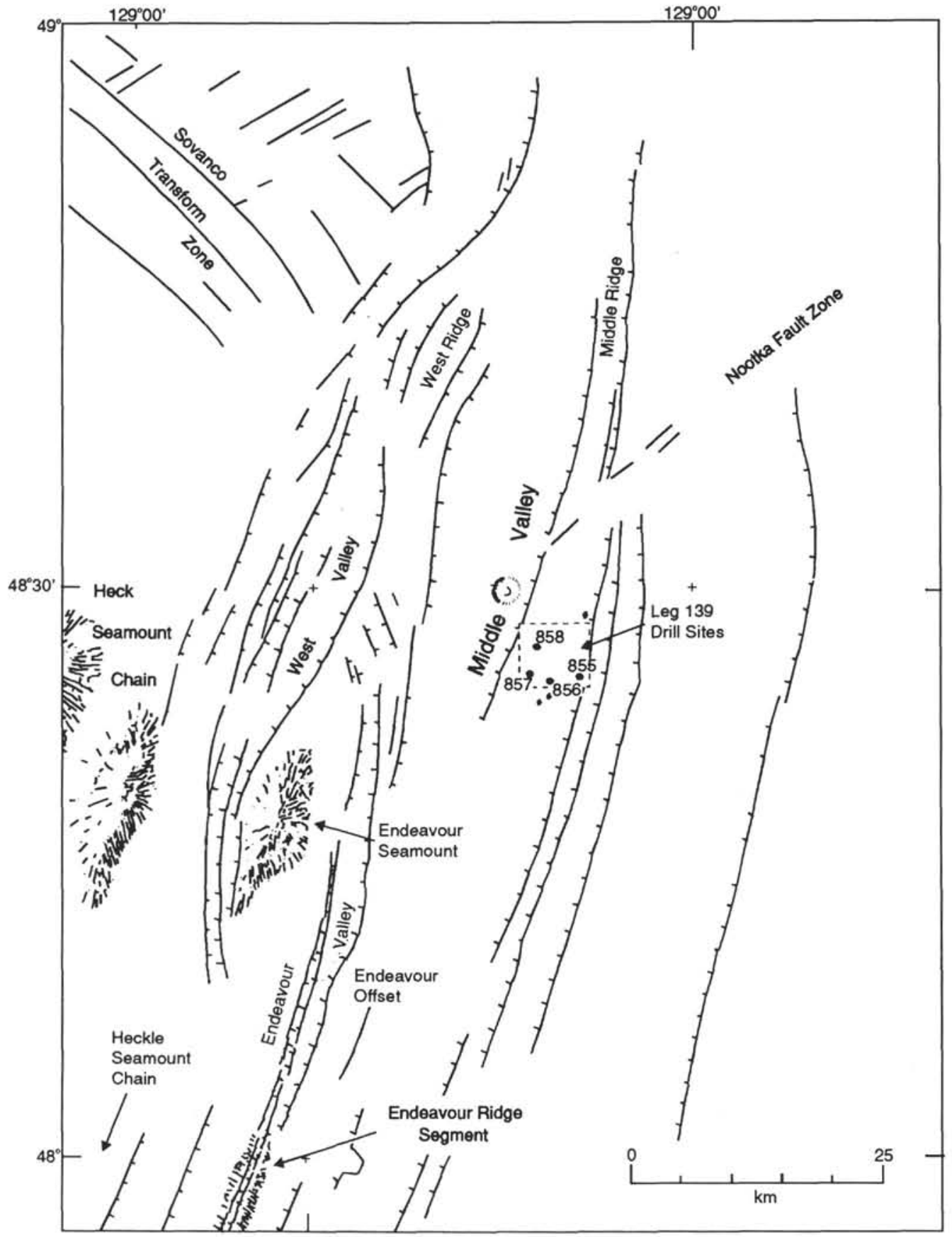

Figure 1. Regional map showing main tectonic features, after Davis and Villinger (1992).

3 (olivine), Table 4 (plagioclase), Table 5 (pyroxene), Table 6 (spinel), Table 7 (magnetite-ilmenite) and Table 8 (sulfide).

Detailed lithostratigraphy and estimates of recovery for all igneous rocks are presented in the Leg 139 Initial Reports volume (Davis, Mottl, Fisher, et al., 1992) and will only be summarized here. The petrographic descriptions presented here supplement the shipboard reconnaissance examination of thin sections, which includes sizes of phenocrysts and modal proportions.

\section{Major and Trace Element Analyses}

Major oxides and some minor and trace elements were determined by fused disk X-ray fluorescence (XRF) at the Geological Survey of Canada. Trace elements including $\mathrm{Ag}, \mathrm{Ba}, \mathrm{Be}, \mathrm{Co}, \mathrm{Cr}, \mathrm{Cu}, \mathrm{Ni}, \mathrm{Pb}, \mathrm{Sc}$,
$\mathrm{Sr}, \mathrm{V}, \mathrm{Zn}$, and $\mathrm{Zr}$ were determined using Inductively-Coupled Plasma Emission Spectrometry (ICP-ES). The rare earth elements, as well as $\mathrm{Y}$, were also determined using inductively-coupled Plasma Mass Spectrometry (ICP-MS), using a total dissolution method (perchloric, nitric, hydrofluoric acids). Combustion and wet chemical methods were used to determine $\mathrm{FeO}$, total $\mathrm{H}_{2} \mathrm{O}\left(=\mathrm{H}_{2} \mathrm{OT}\right)$, total $\mathrm{CO}_{2}\left(=\mathrm{CO}_{2} \mathrm{~T}\right)$ and total sulfur $(=\mathrm{ST})$. Where listed, $\mathrm{FeO}$ is the wet chemistry determinations. Total iron $\left(\mathrm{Fe}_{2} \mathrm{O}_{3} \mathrm{~T}\right)$ was determined by XRF assuming total oxidation on combustion. $\mathrm{FeO}$ is determined by titration and $\mathrm{Fe}_{2} \mathrm{O}_{3}$ is calculated by difference. Values for the $\mathrm{Mg}$ number $\left(=\mathrm{Mg} / \mathrm{Mg}+\mathrm{Fe}^{+2}\right.$ on a molecular basis) are calculated using $\mathrm{Fe}^{+2}=0.9$ (Fe Total) $(=\mathrm{Mg \#})$ and the value for $\mathrm{Fe}_{2} \mathrm{O}_{3} \mathrm{~T}\left(=\mathrm{Mg} \#^{*}\right)$. Detection limits and precision data are available on request to JMF. Data from the shipboard analyses (Davis, Mottl, Fisher, et al., 1992) are also considered where appropri- 
ate. In particular, the shipboard analysis for $\mathrm{Nb}$ is used for comparison with previous work as it is more consistent with other laboratories and previous work in the classification of the basalts. These values are at the detection limit for XRF analysis. In general, however, the data set obtained for this study (Table 1) is considered to be slightly more precise than that for the shipboard analyses, due to more precise weighing.

Alteration of the igneous rocks within an active hydrothermal area can substantially modify whole-rock compositions and obscure primary mineralogy. For each site, we provide an overview of the alteration of the rocks and the extent to which this alteration could have biased the chemical parameters used for igneous petrochemistry. Petrographic observations and oxygen isotope analyses are used to discriminate alteration. Total hydrous alteration can be inferred from total $\mathrm{H}_{2} \mathrm{O}$. That much of the alteration is nonoxidative can be inferred from the measured values for FeO. The impact of sulfide mineralization can be inferred from the values of total sulfur.

\section{Oxygen Isotope Analyses}

Whole-rock powders from shipboard and land-based chemical analyses were analyzed for oxygen isotopes at the University of South Carolina (Table 2). Oxygen isotopes are one of the most sensitive indicators of seawater hydrothermal alteration and are a useful index of alteration. Twelve milligrams of each powder were weighed and dried in a $100^{\circ} \mathrm{C}$ furnace prior to loading onto the extraction line. Samples were reacted with $\mathrm{ClF}_{3}$ to liberate pure oxygen gas, which was then converted to $\mathrm{CO}_{2}$ by reaction with a hot carbon rod. The $\mathrm{CO}_{2}$ was analyzed for its isotopic composition on a SIRA mass spectrometer. Results are reported in the standard $\delta$-notation.

\section{REGIONAL SETTING}

The magmatic history of the northern Juan de Fuca ridge is complicated by ridge propagation and the influence of the adjoining Heck and Heckle Seamount Chain (Fig. 1). The former of these intersects the ridge at the Endeavour Seamount, where the southern end of West Valley and the northern end of the Endeavour Ridge form an overlapping spreading center separated by the Endeavour Offset (Fig. 1). Previous studies suggest that the West Valley segment is propagating to the south while the Endeavour Segment is undergoing ridge failure (Karsten et al., 1990). Middle Valley was the axis of active spreading for the northern Juan de Fuca Ridge prior to approximately $200,000 \mathrm{yr}$ ago. Sometime in the last $200,000 \mathrm{yr}$ and perhaps as recently as 20,000 to $10,000 \mathrm{yr}$ ago, spreading was initiated in West Valley, $20 \mathrm{~km}$ to the west. Active spreading slowed in Middle Valley during this period, especially during the last 10,000 yr (Mottl, Davis, Fisher, et al., 1992). Middle Valley is now bounded by West Ridge and Middle Ridge, which are presumed to have been constructed at the Middle Valley spreading center when it was active. Lavas of primitive compositions have been previously described for West Ridge, whereas West Valley has both primitive (southern end) and evolved compositions (central and northern ends), consistent with ridge propagation to the south (Van Wagoner and Leybourne, 1991). Rocks from the West Valley segment include a large range of variation, explained by (1) heterogeneous mantle, (2) mixing of mantle source domains, and (3) mixing within crustal magma chambers (Van Wagoner and Leybourne, 1991). The Endeavour Segment, which is dominated by compositions slightly more enriched compared to mid-ocean ridge basalt, has secular compositional heterogeneity. The dominance of enriched compositions for the Endeavour Segment has been attributed to reduced melting of an enriched mantle beneath this region associated with the waning stages of this failing segment (Karsten et al., 1990) or due to recent introduction of enriched mantle (Michael et al., 1989). In contrast, the Heck and Heckle Seamount chains are highly depleted, have a restricted range of incompatible elements and are distinct from the adjacent West Valley (Leybourne and Van Wagoner, 1991). Rocks recovered by drilling in Middle Valley can thus be compared to the broadly variable composi- tions in adjacent tectonic domains to test the model of rift failure, temporal variability, and timing of mantle enrichment for the northern portion of the Juan de Fuca Ridge.

\section{Site 855}

\section{Setting}

At Site 855 igneous rock was recovered from the base of each of a series of four drillholes intended to transect the hanging wall and footwall of the eastern boundary fault. Each of these drillholes penetrated less than $20 \mathrm{~m}$ into basement; only a few pieces of fresh porphyritic basalt flows were recovered at the bottom of each hole (Davis, Mottl, Fisher, et al., 1992). Pieces recovered include abundant fresh glass and large phenocrysts of olivine, plagioclase, and clinopyroxene. Some samples have microcrystalline groundmass minerals with variolitic or skeletal textures. The groundmass minerals, in general, have more evolved compositions than the larger phenocrystic minerals. No spinel was observed in any of the samples. Virtually no sulfide was observed in these basalt samples. Fe-oxide was present as a discrete phase only in the more crystalline specimens. Alteration is limited to low-temperature phases such as smectite, celadonite and carbonate, except for rare replacement of olivine by talc or chlorite. The bulk oxygen isotopic values (7.0 to $8.0 \%$ ) are higher than fresh MORB (5.8\%o; Ito et al., 1987) as a result of the presence of the low temperature phases. Plagioclase phenocrysts will also increase the $\delta^{18} \mathrm{O}$ of the powder.

\section{Petrography And Mineral Chemistry}

Olivine phenocrysts tend to be large and rounded to euhedral with rare normal compositional zonation. Some crystals are intergrown with megacrysts of plagioclase or clinopyroxenes to form glomerocrysts. The average composition is $\mathrm{Fo}_{83}$ with a range from $\mathrm{Fo}_{77-86}$ (Table 3).

Plagioclase phenocrysts from Hole 855A have compositions ranging from calcic cores of $\mathrm{An}_{88}$ to more sodic rims of $\mathrm{An}_{76}$ (Table 4). Phenocrysts from Hole $855 \mathrm{D}$ are slightly more sodic in composition, from $\mathrm{An}_{74-68}$. The phenocrysts are euhedral columnar crystals of various sizes that are rarely embayed. Many of the large crystals have abundant inclusions of fresh glass. Most of the larger crystals have oscillatory zoning. Some groundmass plagioclases are skeletal with lantern shapes, but most are lathlike and in radiating aggregates with pyroxene. These small crystals have average compositions of $\mathrm{An}_{70-75}$ with some rims as sodic as $\mathrm{An}_{58}$ (Table 4).

Clinopyroxene phenocrysts are elongate and rounded, frequently twinned, and are included in glomerocrystic aggregates with plagioclase. The large megacrysts $(1-4 \mathrm{~mm})$ are relatively high in $\mathrm{Al}$ contents $\left(>3.5 \% \mathrm{Al}_{2} \mathrm{O}_{3}\right)$ and $\mathrm{Cr}$ contents $\left(>1 \% \mathrm{Cr}_{2} \mathrm{O}_{3}\right)$ (Table 5), characteristics typically associated with high pressure crystallization (Basaltic Volcanism Study Project, 1981). Some of these large crystals poikilitically enclose plagioclase crystals. Like some olivines, the clinopyroxene megacrysts display rims with smaller groundmass phases nucleating on the rounded grain boundaries. Smaller clinopyroxene microphenocrysts and rims on zoned crystals have higher $\mathrm{Ti}$ and $\mathrm{Fe}$, lower $\mathrm{Cr}$, and lower $\mathrm{Al}$ (Table 5) than the large megacrysts. Some smaller clinopyroxenes form "bowtie" intergrowths with laths of plagioclase, or are small barrel-shaped crystals.

\section{Major Elements}

The samples are all very fine-grained to cryptocrystalline or glassy basalt. Alteration is not pronounced and these samples have the lowest volatile contents of any of the suites examined in this study. The three samples analyzed as part of this study are similar to those reported in the Leg 139 Shipboard Report (Davis, Mottl, Fisher, et al., 1992). The major and trace elements (Table 1) indicate that the samples are moderately fractionated abyssal tholeiite. On the $\mathrm{Mg}$-number variation diagrams (Fig. 2), the data are linearly distributed, as expected for frac- 
Table 1. Composition of igneous rocks from Sites 855,856 , and 858 , Middle Valley area.

\begin{tabular}{|c|c|c|c|c|c|c|c|c|c|c|c|c|c|c|c|}
\hline & & & & & & & A. Maj & or elems & & & & & & & \\
\hline $\begin{array}{l}\text { Core, section, } \\
\text { interval }(\mathrm{cm})\end{array}$ & $\begin{array}{l}\text { Depth } \\
\text { (mbsf) }\end{array}$ & $\mathrm{SiO}_{2}$ & $\mathrm{TiO}_{2}$ & $\mathrm{Al}_{2} \mathrm{O}_{3}$ & $\mathrm{Fe}_{2} \mathrm{O}_{3}^{\prime}$ & $\mathrm{Fe}_{2} \mathrm{O}_{3}$ & $\mathrm{FeO}$ & $\mathrm{MnO}$ & $\mathrm{MgO}$ & $\mathrm{CaO}$ & $\mathrm{Na}_{2} \mathrm{O}$ & $\mathrm{K}_{2} \mathrm{O}$ & $\mathrm{H}_{2} \mathrm{O}^{t}$ & $\mathrm{CO}_{2}^{\prime}$ & $\mathrm{P}_{2} \mathrm{O}_{5}$ \\
\hline 139-855A- & & & & & & & & & & & & & & & \\
\hline & 65.0 & 49.50 & 1.66 & 15.70 & 10.80 & 2.80 & 7.20 & 0.20 & 7.82 & 12.00 & 2.40 & 0.16 & 0.3 & 0.30 & 0.17 \\
\hline $9 \mathrm{R}-1,46-48$ & 74.8 & 49.70 & 1.45 & 15.20 & 9.90 & 2.70 & 6.50 & 0.16 & 7.68 & 12.10 & 2.80 & 0.12 & 0.8 & 0.30 & 0.12 \\
\hline $\begin{array}{l}139-855 \mathrm{D} \\
6 \mathrm{R}-1,40-42\end{array}$ & 114.3 & 49.70 & 1.57 & 14.20 & 11.30 & 2.60 & 7.80 & 0.19 & 7.69 & 11.90 & 2.50 & 0.12 & 0.7 & 0.40 & 0.13 \\
\hline 139-856A- & & & & & & & & & & & & & & & \\
\hline & 115.4 & 47.70 & 0.84 & 15.90 & 8.80 & 2.60 & 5.60 & 0.15 & 11.20 & 11.60 & 1.90 & 0.05 & 2.6 & 0.20 & 0.05 \\
\hline $14 X-1,7-9$ & 115.9 & 47.60 & 0.83 & 15.80 & 8.90 & 2.20 & 6.00 & 0.15 & 11.40 & 11.70 & 1.90 & 0.05 & 2.3 & 0.20 & 0.05 \\
\hline $14 \mathrm{X}-\mathrm{CC}, 9-11$ & 114.6 & 47.10 & 0.81 & 15.60 & 8.90 & 2.20 & 6.00 & 0.14 & 12.40 & 10.50 & 1.80 & 0.05 & 3.1 & 0.10 & 0.05 \\
\hline 139-856B- & & & & & & & & & & & & & & & \\
\hline $10 \mathrm{H}-1,64-67$ & 71.4 & 47.10 & 0.86 & 16.30 & 8.20 & 2.20 & 5.40 & 0.12 & 11.40 & 9.60 & 2.00 & 0.02 & 3.1 & 0.40 & 0.06 \\
\hline $10 \mathrm{H}-1.9$ & 71.7 & 45.80 & 1.13 & 20.80 & 5.30 & 0.90 & 4.00 & 0.04 & 8.37 & 6.56 & 2.50 & 0.02 & 6,9 & 0,10 & 0.04 \\
\hline $10 \mathrm{H}-2,9-12$ & 72.4 & 46,30 & 0.86 & 16.20 & 8.20 & 2.60 & 5.00 & 0.11 & 11.70 & 9.23 & 1.90 & 0.02 & 3.8 & 0.30 & 0.05 \\
\hline $139-857 \mathrm{C}$ & & & & & & & & & & & & & & & \\
\hline $59 R-1,131-133$ & 472.4 & 50.00 & 1.62 & 15.00 & 9.40 & 1.50 & 7.10 & 0.19 & 7.52 & 12.20 & 2.30 & 0.02 & 1.7 & 0.10 & 0.18 \\
\hline $59 \mathrm{R}-2,62-64$ & 473.2 & 50.30 & 1.62 & 15.30 & 9.20 & 1.20 & 7.20 & 0.17 & 7.61 & 12.10 & 2.30 & 0.02 & 1.8 & 0,10 & 0.18 \\
\hline $59 \mathrm{R}-2,94-96$ & 473.5 & 49.80 & 1.65 & 14.70 & 10.00 & 1.60 & 7.60 & 0.18 & 7.93 & 12.20 & 2.20 & 0.02 & 2.0 & 0.20 & 0.18 \\
\hline $59 \mathrm{R}-3,40-42$ & 69.9 & 50.50 & 1.68 & 14.70 & 9.00 & 1.10 & 7.10 & 0.17 & 8.22 & 12.40 & 2.30 & 0.02 & 8 & 0.10 & 0.18 \\
\hline $59 \mathrm{R}-3,117-119$ & 475.2 & 50.90 & 1.53 & 14.50 & 8.40 & 0.80 & 6.80 & $0.1 \quad$ r & 8.05 & 11.90 & 2.10 & 0.02 & 11 & 0.20 & \\
\hline $59 R-4,35$ & 475.9 & 51.50 & 1.55 & 15.20 & 7.90 & 1.20 & 6.00 & 0.17 & 7.60 & 12.10 & 2.40 & 0.02 & 1.6 & 0.20 & \\
\hline $59 R-4,111-113$ & 476.6 & 49.30 & 1.58 & 15.20 & 9.70 & 1.60 & 7.30 & 0.22 & 7.27 & 11.90 & 2.30 & 0.02 & 2,0 & 0.10 & 0.17 \\
\hline $60 R-1,32-34$ & 481.1 & 47.50 & 1.61 & 15.00 & 10.20 & & & 0.25 & 7.72 & 12.40 & 2.30 & 0.02 & & & 0.17 \\
\hline $60 R-1,75-77$ & 481.6 & 49.60 & 1.61 & 14.70 & 9.40 & & & 0.19 & 7.56 & 12.30 & 2.30 & 0.02 & & 0.10 & 0.17 \\
\hline $60 R-1,173-175$ & 482.5 & 48.20 & 1.61 & 15.40 & 9.50 & 1.30 & 7.40 & 0.22 & 8.29 & 12.50 & 2.30 & 0.02 & 2.1 & & 0.17 \\
\hline $60 R-2,12-14$ & 482.3 & 47.90 & 1.57 & 15.10 & 10.20 & & & 0.22 & 7.60 & 12.30 & 2.40 & 0.02 & & & 0.17 \\
\hline $60 \mathrm{R}-2,28-30$ & 482.5 & 46.10 & 1.85 & 16.10 & 9.10 & 1.00 & 7.30 & 0.24 & 10.40 & 9.20 & 2.80 & 0.02 & 3.9 & 0.10 & 0.20 \\
\hline 61 & 490.8 & 47.80 & 1.43 & 14.40 & 12.20 & & & 0.24 & 10.10 & 8.19 & 1.60 & 0.02 & & 0.10 & \\
\hline 61 & 491.9 & 44.50 & 1.56 & 16.40 & 9.90 & 1.70 & 7.40 & 0.31 & 12.50 & $\begin{array}{l}.19 \\
5.60\end{array}$ & 2.20 & 0.02 & 6.2 & 0.10 & 0.14 \\
\hline $62 \mathrm{R}-1,20-22$ & 500.2 & 48.20 & 1.26 & 15.10 & 10.60 & & & 0.26 & 10.10 & 7.92 & 1.80 & 0.02 & & 0.10 & 0.12 \\
\hline $62 \mathrm{R}-1,6$ & 500.7 & 48.00 & 1.03 & 15.60 & 11.60 & & & 0.25 & 7.59 & 10.30 & 1.20 & 0.02 & & 0.10 & \\
\hline $62 \mathrm{R}-2$ & 501.6 & 47.90 & 0.92 & 15.60 & 7.30 & 1.10 & 5.60 & 0.24 & 11.80 & 9.80 & 2.30 & 0.02 & 3.8 & 0.10 & 0.07 \\
\hline $62 \mathrm{R}-2,50-52$ & 502.0 & 48.60 & 1.53 & 16.60 & 7.80 & 1.10 & 6.00 & 0.27 & 9.27 & 10.00 & 2.60 & 0.02 & 2.3 & & 0.14 \\
\hline $63 \mathrm{R}-1,38-40$ & 510.1 & 49.20 & 1.35 & 15.50 & 9.50 & 1.30 & 7.40 & 0.29 & 9.70 & 9.38 & 2.00 & 0.02 & 3.4 & 0.10 & 0.13 \\
\hline $63 \mathrm{R}-1$ & 510.4 & 47.30 & 151 & 15.90 & 9.50 & 130 & 7.40 & 0.24 & 9.36 & 11.50 & 1.90 & 0.02 & 2.7 & & 0.14 \\
\hline $64 R-1$ & 519.5 & 53.50 & 1.30 & 14.50 & 8.70 & & & 0. & 7.07 & 9.23 & 2.00 & 0.02 & & 0.10 & 0.1 \\
\hline $64 \mathrm{R}-1,112-114$ & 520.5 & 48.90 & 1.36 & 15.50 & 9.40 & 1.40 & 7.20 & 0.24 & 8.47 & 12.20 & 2.10 & 0.02 & 2.1 & 0.10 & 0.13 \\
\hline $8-2,74$ & 521.6 & 44.60 & 1.63 & 15.20 & 12.30 & 1.60 & 9.60 & 0.30 & 11.10 & 9.31 & 1.50 & 0.02 & 4.3 & & 0.14 \\
\hline & 539.3 & 45.90 & 2.08 & 15.30 & 11.20 & 1.90 & 8.40 & & 8.34 & 11.30 & & 0.02 & 3.1 & 0.10 & \\
\hline & 540.0 & 47.50 & 2.05 & 15.70 & 10.20 & & & & 7.27 & 11.60 & 20 & 0.0 & & 0.1 & \\
\hline 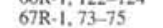 & 549.1 & 47.50 & 1.53 & 15.70 & 10.40 & 1.50 & 8.00 & 0.31 & 8.91 & 11.30 & 1.60 & 0.02 & 2.9 & 0.10 & 0.14 \\
\hline $2-1,12-14$ & 558.1 & 45.90 & 1.56 & 16.80 & 11.80 & 1.70 & 9.10 & 0.38 & 9.18 & 9.21 & i.so & 0.02 & 3.9 & 0.10 & 0.16 \\
\hline & $\begin{array}{l}558.9 \\
558.1\end{array}$ & 47.80 & 1.52 & 15.9 & 10.10 & 1.30 & 7.90 & & 9.29 & 11.40 & & 0.0 & & 0.10 & \\
\hline & 559.8 & 47.70 & 1.71 & 15.9 & & 1.4 & 7.80 & & & 11.60 & & & 2.5 & & \\
\hline R-2, 72-74 & 560.2 & 45.40 & 1.73 & 17.10 & $\begin{array}{l}11.00 \\
11.00\end{array}$ & 1.40 & 8.60 & 0.39 & $\begin{array}{l}0.40 \\
9.04\end{array}$ & 10.00 & 1.60 & 0.02 & 3.6 & 0.10 & 0.18 \\
\hline $68 \mathrm{R}-3,11-13$ & 561.1 & 47.60 & 1.52 & 15.70 & 10.10 & 2.10 & $\begin{array}{l}0.00 \\
7.20\end{array}$ & 0.31 & 9.70 & 10.10 & 1.50 & 0.02 & 3.9 & 0.10 & 0.14 \\
\hline $139-857 \mathrm{D}$ & & & & & & & & & & & & & & & \\
\hline 3 & 00.5 & 38.40 & 1.73 & 18.50 & 15.30 & 2.40 & 11.60 & 0.35 & 12.30 & 6.08 & 1.30 & 0.02 & 6.9 & 0.10 & \\
\hline & & 37.40 & & & & & & & 12.80 & & & & & & \\
\hline & 48.3 & 50.10 & 2.27 & 13.70 & 11.70 & 1.50 & 9.20 & 0.24 & 6.74 & 10.90 & 2.20 & 0.02 & 2.2 & 0.10 & 0.20 \\
\hline & 6 & 43.7 & 1. & 16.6 & 11.6 & 1.90 & 70 & & 14.2 & 3.92 & 0. & 0.0 & 8.4 & 0.10 & 0. \\
\hline & 8 & 49.7 & & 15.8 & & 1.70 & $\begin{array}{l}8.70 \\
7.20\end{array}$ & & 7.8 & 11. & & 0. & 1.8 & & \\
\hline & & 48.10 & 1.4 & 15.9 & 8.8 & 2.70 & 5.50 & & & 14.10 & & & 1.6 & & \\
\hline $\mathrm{R}-2,114-116$ & 03.8 & 48.30 & 1.38 & 15.40 & $\begin{array}{l}8.80 \\
8.50\end{array}$ & & & 0.22 & $\begin{array}{l}8.07 \\
8.15\end{array}$ & 14.30 & 2.10 & 0.02 & & & 0.15 \\
\hline & & 50. & 1. & 15. & 8. & 1.50 & 6.20 & & & 12. & & 0. & 1.7 & & \\
\hline & & 49 & $i$. & 15.8 & & $\begin{array}{l}1.30 \\
2.50\end{array}$ & $\begin{array}{l}0.20 \\
6.20\end{array}$ & & & 12 & & 0.0 & 2.0 & & \\
\hline & & 4 & 13 & 15.4 & 9.5 & & & & & 12.00 & & & & & \\
\hline & & 49.20 & 1.9 & 14.8 & 11.20 & 1.80 & 8.50 & 0. & 7.38 & 11.90 & 2 & 0.0 & 2.0 & 0.10 & $\begin{array}{l}0.19 \\
0.19\end{array}$ \\
\hline $36 \mathrm{R}-1,74-76$ & 917.6 & 49.00 & 2.05 & 13.90 & 12.30 & 2.90 & 8.50 & 0.22 & 6.68 & 11.50 & 2.10 & 0.02 & 2.2 & 0.10 & 0.17 \\
\hline $139.858 \mathrm{~F}$ & & & & & & & & & & & & & & & \\
\hline & 50.1 & 45.10 & 1.76 & 17.30 & 10.30 & & & & & & & & & & \\
\hline & & & & & 9. & & & & & & & & & & \\
\hline & 2 & 48 & 15 & & 9. & & & & 7. & 12 & & & 1.4 & 0 & \\
\hline $29 \mathrm{R}-1,63-65$ & 287.8 & 48.80 & 1.61 & 15.70 & 8.70 & 1.50 & 6.50 & 0.15 & 8.64 & 10.80 & 3.40 & 0.02 & 2.5 & 0.10 & 0.17 \\
\hline 139-858G. & & & & & & & & & & & & & & & \\
\hline & 17.2 & 47.70 & 1.60 & & & & & & & & & & & & \\
\hline & & & & & & & & & & & & & & & \\
\hline & & 48 & 1.5. & & & & & & 75 & & & & & 0.12 & \\
\hline & & & & & & 2.20 & & & & & & & & 0.20 & \\
\hline & & 48. & 1.5 & 15 & 9. & 1.20 & $\begin{array}{l}0.100 \\
6.80\end{array}$ & & & 13 & & & & & \\
\hline & & & & & 9. & & & & & & & & & & \\
\hline & & 48 & i. & & & 1.70 & 6.50 & & & & & & 2.4 & & \\
\hline & & & 1.5 & & 9.0 & 1.40 & 6.80 & & & 12. & & & 2.4 & & \\
\hline & 15.6 & 47.40 & 15 & 15.8 & 10.5 & & & & & 12. & 2 & 0.0 & & 0.10 & 0.1 \\
\hline & & 48.40 & 1.5 & 15. & 9. & & & & 7. & 12. & & & & 0.10 & \\
\hline & & & 1.5 & & & 1.40 & 6.90 & & & & & & 1.5 & & \\
\hline & 3 & 49.9 & 1.55 & 15.2 & 8.9 & 1.60 & 6.60 & 0.1 & & 12. & 3. & 0.0 & 1.6 & 0.10 & \\
\hline & 3 & 46.9 & 1.53 & 15.5 & 10.7 & & & 0.1 & 7 & 12 & 2. & $\begin{array}{l}0.02 \\
0.02\end{array}$ & & $\begin{array}{l}0.10 \\
0.10\end{array}$ & 0.1 \\
\hline & & 48. & & & 9.6 & 1.3 & 7.5 & & & 12. & & & 2.1 & & \\
\hline & & & & & & & & & & & & & 1.7 & & \\
\hline 14 & 4 & 48.4 & 1.56 & 15.6 & 8.90 & 2.20 & 6.00 & 0.15 & 7.30 & 13.00 & 2.60 & 0.02 & 2.2 & 0.10 & 0.17 \\
\hline & 413. & $\begin{array}{l}47,30 \\
47,30\end{array}$ & 16 & $\begin{array}{l}13.0 \\
16.4\end{array}$ & 9.70 & 2.20 & $\begin{array}{l}8.00 \\
6.80\end{array}$ & $0.1 .12-3$ & 70 & $\begin{array}{l}13.00 \\
13.20\end{array}$ & 2.70 & 0.02 & 1.2 & & 0.18 \\
\hline $16 \mathrm{R}-1.77-79$ & 423.7 & 49.40 & 1.58 & 14.00 & 9.70 & & & 0.17 & 8.00 & 10.50 & 3.30 & 0.02 & & 0.10 & 0.16 \\
\hline
\end{tabular}

$\mathrm{Fe}^{2+}=\mathrm{Fe}$ total. All analyses by fused disk $\mathrm{X}$-ray fluoreseence except $\mathrm{H}_{2} \mathrm{O}$ and $\mathrm{CO}_{2}$ by combustion.

tionation. On a $\mathrm{CaO} / \mathrm{Al}_{2} \mathrm{O}_{3}$ vs. $\mathrm{Mg} \#$ diagram, they fall within the range of the Endeavour Segment samples (Davis, Mottl, Fisher, et al., 1992).

\section{Trace Elements}

Basalts can be classified as enriched mid-ocean ridge basalt (EMORB), transitional mid-ocean ridge basalt (T-MORB) or normal 
B. Minor and trace elements

\begin{tabular}{|c|c|c|c|c|c|c|c|c|c|c|c|c|c|c|c|}
\hline & & & & & & & & & & & & & inor & tra & eler \\
\hline $\begin{array}{l}\text { Core, section, } \\
\text { interval }(\mathrm{cm})\end{array}$ & St & $\mathrm{Ba}$ & $\mathrm{Be}$ & Co & $\mathrm{Cr}$ & $\mathrm{Cu}$ & $\mathrm{La}$ & $\mathrm{Nb}$ & $\mathrm{Ni}$ & $\mathrm{Pb}$ & $\mathrm{Sc}$ & $\mathrm{Sr}$ & $\mathrm{V}$ & $\mathrm{Y}$ & $\mathrm{Yb}$ \\
\hline 139-855A- & & & & & & & & & & & & & & & \\
\hline $8 \mathrm{R}-1,18-20$ & 0.08 & 40 & 0.6 & 44 & 240 & 68 & 3.8 & 13 & 140 & & 34 & 110 & 280 & 40 & 4.4 \\
\hline $9 R-1,46-48$ & 0.08 & 80 & 0.6 & 43 & 230 & 68 & 3.8 & 13 & 100 & & 37 & 140 & 260 & 32 & 3.5 \\
\hline $\begin{array}{l}139-855 \mathrm{D}- \\
6 \mathrm{R}-1,40-42\end{array}$ & 0.16 & 40 & 0.6 & 43 & 200 & 64 & 3.5 & 12 & 77 & & 40 & 130 & 290 & 36 & 4.0 \\
\hline 139-856A- & & & & & & & & & & & & & & & \\
\hline $14 \mathrm{X}-1,90-92$ & 0.09 & 60 & & 42 & 560 & 69 & 0.9 & 15 & 250 & & 28 & 63 & 170 & 21 & 2.4 \\
\hline $14 X-1,7-9$ & 0.14 & 50 & & 42 & 550 & 66 & 0.9 & 13 & 240 & & 28 & 64 & 170 & 22 & 2.3 \\
\hline 14X-CC, 9-11 & 0.14 & 30 & & 49 & 610 & 74 & 0.9 & 11 & 300 & & 28 & 60 & 170 & & 2.3 \\
\hline 139-856B- & & & & & & & & & & & & & & & \\
\hline $10 \mathrm{H}-1,64-67$ & 0.12 & 60 & & 43 & 540 & 73 & 1.2 & 11 & 260 & 22 & 28 & 77 & 170 & 21 & 2.4 \\
\hline $10 \mathrm{H}-1.93-95$ & 0.75 & 80 & 0.5 & 62 & 810 & 180 & 1.6 & 5 & 380 & 22 & 37 & 88 & 220 & 8.6 & 1.7 \\
\hline $10 \mathrm{H}-2,9-12$ & 0.14 & 60 & & 42 & 580 & 66 & 0.9 & 5 & 260 & & 27 & 69 & 160 & 21 & 2.3 \\
\hline $\begin{array}{l}139-857 \mathrm{C}- \\
\end{array}$ & & & & & & & & & & & & & & & \\
\hline $59 \mathrm{R}-1,131-133$ & 0.07 & 30 & 0.7 & 37 & 280 & 81 & 6.1 & 13 & 76 & & 37 & 210 & 260 & 32 & 3.2 \\
\hline $59 \mathrm{R}-2,62-64$ & 0.39 & 60 & 0.8 & 32 & 270 & 58 & 6.4 & 14 & 76 & & 37 & 220 & 250 & 31 & 3.2 \\
\hline $59 \mathrm{R}-2,94-96$ & 0.10 & 80 & 0.8 & 35 & 260 & 54 & 6.4 & 13 & 75 & & 37 & 200 & 250 & 32 & 3.3 \\
\hline $59 \mathrm{R}-3,40-42$ & 0.18 & 60 & 0.8 & 33 & 280 & 67 & 6 & 13 & 69 & & 40 & 200 & 250 & 32 & 3.4 \\
\hline $59 \mathrm{R}-3,117-119$ & 0.03 & 30 & 0.7 & 32 & 280 & 53 & 5.7 & 5 & 84 & & 34 & 200 & 220 & 29 & 2.9 \\
\hline $59 R-4,35-37$ & 0.02 & 70 & 0.7 & 26 & 270 & 80 & 5.7 & 12 & 81 & & 36 & 220 & 230 & 30 & 3.1 \\
\hline $59 \mathrm{R}-4,111-113$ & 0.44 & 40 & 0.7 & 32 & 260 & 120 & 6.4 & 14 & 79 & & 35 & 210 & 230 & 30 & 3.2 \\
\hline 60R-1, 32-34 & 2.65 & 50 & 0.8 & 37 & 250 & 41 & 5.8 & iI & 73 & & 37 & 210 & 240 & 31 & 3.4 \\
\hline $60 \mathrm{R}-1.75-77$ & 1.59 & 70 & 0.8 & 36 & 240 & 84 & 5.8 & 12 & 72 & & 37 & 210 & 240 & 31 & 3.4 \\
\hline $60 \mathrm{R}-1,173-175$ & 0.63 & 60 & 0.7 & 31 & 270 & 91 & 6 & 5 & 75 & 70 & 37 & 200 & 240 & 30 & 3.2 \\
\hline $60 \mathrm{R}-2,12-14$ & 2.28 & 50 & 0.7 & 38 & 250 & 50 & 6.4 & 12 & 85 & & 37 & 210 & 240 & 31 & 3.4 \\
\hline $60 \mathrm{R}-2,28-30$ & 0.12 & 70 & 1.2 & 32 & 310 & 14 & 6 & 5 & 81 & & 42 & 210 & 260 & 30 & 3.2 \\
\hline $61 \mathrm{R}-1.32-34$ & 1.79 & 50 & 0.8 & 46 & 230 & 37 & 6.2 & 14 & 79 & & 32 & 140 & 210 & 26 & 2.9 \\
\hline $61 R-2,4-6$ & 0.90 & 70 & 1.3 & 32 & 310 & 5 & 3.8 & 5 & 90 & & 39 & 140 & 240 & 31 & 3.4 \\
\hline $62 \mathrm{R}-1,20-22$ & 1.13 & 80 & 0.5 & 39 & 250 & 79 & 3.5 & 11 & 84 & & 31 & 180 & 190 & 26 & 2.7 \\
\hline $62 \mathrm{R}-1.67-69$ & 1.80 & 70 & 0.5 & 36 & 190 & 17 & 3.4 & 5 & 74 & & 26 & 140 & 220 & 23 & 2.4 \\
\hline $62 \mathrm{R}-2,7-9$ & 0.03 & 30 & & 30 & 360 & 5 & 1.7 & 12 & 83 & & 43 & 160 & 180 & 18 & 2.0 \\
\hline $62 \mathrm{R}-2,50-52$ & 0.33 & 60 & 0.6 & 29 & 310 & 84 & 3.7 & 5 & 91 & & 38 & 180 & 220 & 29 & 3.1 \\
\hline $63 \mathrm{R}-1,38-40$ & 0.07 & 50 & 0.7 & 32 & 300 & 21 & 4.1 & 5 & 93 & & 35 & 140 & 210 & 27 & 3.0 \\
\hline $63 \mathrm{R}-1,69-71$ & 0.25 & 80 & 0.7 & 27 & 340 & 34 & 4.5 & 5 & 84 & & 40 & 140 & 240 & 30 & 3.3 \\
\hline $64 \mathrm{R}-1,13-15$ & 1.58 & 50 & 0.6 & 35 & 280 & 21 & 4.1 & 14 & 81 & 33 & 34 & 150 & 210 & 26 & 2.7 \\
\hline $64 R-1,112-114$ & 0.83 & 50 & 0.7 & 30 & 300 & 79 & 4.2 & 13 & 85 & & 37 & 150 & 220 & 28 & 2.9 \\
\hline $64 R-2,74-76$ & 0.31 & 40 & 0.7 & 30 & 310 & 78 & 4.3 & 11 & 86 & & 39 & 110 & 250 & 30 & 3.2 \\
\hline $66 \mathrm{R}-1.94-96$ & 0.62 & 70 & 0.9 & 39 & 240 & 63 & 9.1 & 15 & 120 & & 35 & 150 & 260 & 39 & 4.3 \\
\hline $66 \mathrm{R}-1,122-124$ & 1.05 & 70 & 0.8 & 53 & 240 & 130 & 8.9 & 20 & 120 & & 34 & 170 & 260 & 37 & 4.1 \\
\hline $67 \mathrm{R}-1,73-75$ & 0.02 & 40 & 0.9 & 36 & 270 & 100 & 5.5 & 16 & 98 & & 35 & 120 & 260 & 31 & 3.3 \\
\hline $68 \mathrm{R}-1,12-14$ & 0.46 & 60 & 0.7 & 35 & 280 & 220 & 6.6 & 12 & 100 & & 36 & 110 & 260 & 32 & 3.6 \\
\hline $68 \mathrm{R}-1,90-92$ & 0.08 & 50 & 0.7 & 33 & 280 & 130 & 5.7 & 14 & 100 & & 34 & 110 & 250 & 31 & 3.4 \\
\hline $68 \mathrm{R}-2,28-30$ & 0.51 & 60 & 0.7 & 36 & 260 & 180 & 6.3 & 5 & 96 & & 36 & 130 & 270 & 34 & 3.7 \\
\hline $68 \mathrm{R}-2,72-74$ & 0.22 & 80 & 0.7 & 36 & 180 & 240 & 6.8 & 19 & 110 & & 33 & 120 & 260 & 35 & 3.8 \\
\hline $68 R-3,11-13$ & 0.01 & 15 & 0.8 & 36 & 290 & 44 & 5.4 & 10 & 100 & 23 & 36 & 110 & 260 & 31 & 3.4 \\
\hline 139-857D- & & & & & & & & & & & & & & & \\
\hline $3 R-1,117-120$ & 0.34 & 70 & 0.5 & 45 & 290 & 680 & 3.6 & 15 & 86 & & 38 & 110 & 230 & 36 & 3.9 \\
\hline $4 R-1,138-140$ & 1.91 & 30 & & 47 & 160 & 1700 & 2 & 15 & 74 & & 26 & 68 & 210 & 24 & 2.5 \\
\hline $8 R-1,96-98$ & 0.51 & 60 & 1 & 35 & 56 & 120 & 6.2 & 5 & 41 & & 39 & 120 & 340 & 47 & 5.5 \\
\hline $12 \mathrm{R}-1,88-90$ & 0.57 & 30 & & 33 & 320 & 5 & 2.8 & 16 & 140 & & 35 & 26 & 240 & 34 & 3.9 \\
\hline $24 R \cdot 1,115-117$ & 0.71 & 30 & 0.6 & 36 & 260 & 76 & 5.7 & 13 & 68 & & 35 & 160 & 230 & 27 & 2.9 \\
\hline $24 \mathrm{R}-2,64-66$ & 0.02 & 60 & 0.5 & 32 & 240 & 220 & 5.6 & 10 & 66 & & 35 & 300 & 240 & 27 & 2.9 \\
\hline $24 R-2,114-116$ & 1.14 & 80 & 0.6 & 30 & 250 & 29 & 5.8 & 12 & 67 & & 35 & 240 & 240 & 29 & 3.0 \\
\hline $24 \mathrm{R}-3,24-26$ & 0.98 & 60 & 0.6 & 35 & 250 & II & 5.7 & 12 & 63 & & 35 & 220 & 230 & 27 & 2.6 \\
\hline $25 R-1.64-66$ & 0.01 & 50 & 0.6 & 31 & 260 & 99 & 5.6 & 5 & 68 & & 36 & 190 & 230 & 28 & 2.7 \\
\hline $26 \mathrm{R}-1,76-78$ & 1.00 & 50 & 0.6 & 38 & 250 & 56 & 5.9 & 16 & 67 & & 35 & 170 & 230 & 28 & 2.9 \\
\hline $32 \mathrm{R}-1,58-61$ & 0.12 & 40 & 0.6 & 36 & 150 & 5 & 6.1 & 13 & 69 & & 38 & 140 & 300 & 39 & 4.1 \\
\hline $36 \mathrm{R}-1,74-76$ & 0.74 & 70 & 0.6 & 40 & 170 & 56 & 5.4 & 5 & 64 & & 38 & 110 & 330 & 44 & 4.8 \\
\hline $139.858 \mathrm{~F}-$ & & & & & & & & & & & & & & & \\
\hline $25 R-1,118-119$ & 2.73 & 130 & 1.5 & 45 & 340 & 110 & 5.8 & 13 & 110 & 30 & & 230 & 250 & 33 & 3.2 \\
\hline $26 \mathrm{R}-1,42-44$ & 0.33 & 90 & 0.9 & 42 & 320 & 85 & 6.7 & 13 & 99 & & 38 & 210 & 2. & 3 & 3.0 \\
\hline $27 \mathrm{R}-1,42-43$ & 0.01 & 50 & 0.8 & 41 & 330 & 85 & 6.8 & 14 & 100 & & 39 & 220 & 250 & 30 & 2.9 \\
\hline $29 \mathrm{R}-1,63-65$ & 0.01 & 80 & 0.8 & 45 & 360 & 87 & 6.3 & 5 & 110 & & 39 & 200 & 240 & 31 & 3.1 \\
\hline 139-858G- & & & & & & & & & & & & & & & \\
\hline IR-1, 37-39 & 0.62 & 70 & 0.7 & 42 & 290 & 83 & 6.9 & 5 & 93 & & 38 & 220 & 240 & 31 & 3.1 \\
\hline $2 \mathrm{R}-1,53-55$ & 0.02 & 40 & 0.8 & 33 & 290 & 71 & 6.7 & 5 & 92 & & 37 & 230 & 230 & 31 & 3.1 \\
\hline $3 R-1,24-25$ & 0.09 & 90 & 0.8 & 33 & 300 & 71 & 6.4 & 12 & 87 & & 38 & 200 & 240 & 31 & 3.1 \\
\hline $4 \mathrm{R}-1,26-28$ & 0.05 & 60 & 0.8 & 32 & 310 & 73 & 7.2 & 13 & 85 & & 38 & 210 & 240 & 31 & 3.2 \\
\hline $4 \mathrm{R}-1,71-73$ & 0.28 & 60 & 0.8 & 36 & 300 & 69 & 6.9 & 5 & 89 & & 39 & 220 & 250 & 30 & 3.0 \\
\hline $8 R-1,36-38$ & 0.09 & 90 & 0.7 & 35 & 290 & 130 & 6.3 & 11 & 90 & & 38 & 200 & 240 & 30 & 3.1 \\
\hline $7 \mathrm{R}-1,33-35$ & 0.02 & 15 & 0.8 & 33 & 330 & 84 & 5.8 & 13 & 85 & 23 & 39 & 200 & 240 & 31 & 3.2 \\
\hline $6 \mathrm{R}-1,29-32$ & 0.33 & 60 & 0.8 & 33 & 300 & 85 & 6.5 & iI & 89 & 28 & 38 & 220 & 240 & 30 & 3.2 \\
\hline & 1.28 & 70 & 0.7 & 40 & 330 & 56 & 6.8 & 15 & 93 & 43 & 40 & 220 & 25 & 29 & 2.9 \\
\hline $10 \mathrm{R}-1,31-33$ & 1.13 & 80 & 0.8 & 39 & 290 & 60 & 6.3 & 15 & 85 & & 37 & 210 & 230 & 30 & 3.0 \\
\hline $10 \mathrm{R}-1,104-106$ & 0.70 & 70 & 0.7 & 43 & 300 & 190 & 7 & 10 & 90 & & 39 & 220 & 250 & 31 & 3.0 \\
\hline & 0.02 & 60 & 0.8 & 36 & 300 & 76 & 6.2 & 11 & 85 & & 39 & 21 & 25 & 31 & 3.3 \\
\hline $12 \mathrm{R}-1,48-50$ & 2.02 & 60 & 0.8 & 44 & 300 & 49 & 6.4 & 12 & 94 & & 39 & 220 & 240 & 30 & 3.0 \\
\hline $13 \mathrm{R}-1,9-11$ & 0.16 & 80 & 0.7 & 41 & 280 & 260 & 6.5 & 5 & 98 & & 36 & 220 & 240 & 31 & 3.1 \\
\hline & 0.76 & 40 & 0.8 & 46 & 310 & 95 & 6.5 & 5 & 94 & & 39 & 220 & 250 & 31 & 3.0 \\
\hline $14 R-1,41-43$ & 0.04 & 60 & 0.7 & 35 & 310 & 100 & 6.2 & 5 & 91 & & 40 & 220 & 250 & 30 & 3.0 \\
\hline $15 R-1,31-33$ & 0.78 & 50 & 0.8 & 52 & 300 & 170 & 6.6 & 14 & 99 & & $4 t$ & 210 & 260 & 31 & 3.1 \\
\hline $16 \mathrm{R}-1,77-79$ & 1.29 & 60 & 0.7 & 43 & 340 & 55 & 6.3 & 10 & 84 & & 40 & 220 & 250 & 29 & 2.8 \\
\hline
\end{tabular}

Notes: For $[\mathrm{La} / \mathrm{Ce}]_{\mathrm{n}}$ and $[\mathrm{La} / \mathrm{Sm}] \mathrm{n}, \mathrm{n}$ signifies that values are normalized to chondritic values. Analyses of trace elements by ICP-ES. Analyses of $\mathrm{Y}$ and REE by ICP-MS.

mid-ocean ridge basalt $(\mathrm{N}-\mathrm{MORB})$ based on $\mathrm{Zr} / \mathrm{Nb},[\mathrm{La} / \mathrm{Sm}]_{\mathrm{n}}(\mathrm{Le}$ Roex et al., 1983; Karsten et al., 1990; Michael et al., 1989) or [La/Ce] (Langmuir et al., 1977; Basaltic Volcanism Study Group, 1981; Van Wagoner and Leybourne, 1991). We are using the classifications adopted by Karsten et al. (1990) for $\mathrm{Zr} / \mathrm{Nb}$ and Van Wagoner and Leybourne (1991) for [ $\mathrm{La} / \mathrm{Ce}] \mathrm{n}$. The low $\mathrm{Nb}$ content in these samples renders the $\mathrm{Zr} / \mathrm{Nb}$ values of questionable value. These will be referred to based on shipboard $\mathrm{Nb}$ values, but basalt classification 
Table 2. Oxygen isotopic compositions of whole rock powders.

\begin{tabular}{|c|c|c|c|c|c|}
\hline $\begin{array}{l}\text { Core, section, } \\
\text { interval }(\mathrm{cm})\end{array}$ & $\begin{array}{l}\text { Depth } \\
\text { (mbsf) }\end{array}$ & $\mathrm{O}^{18}$ & $\begin{array}{l}\text { Core, section, } \\
\text { interval }(\mathrm{cm})\end{array}$ & $\begin{array}{l}\text { Depth } \\
\text { (mbsf) }\end{array}$ & $\mathrm{O}^{18}$ \\
\hline \multicolumn{3}{|l|}{$139-855 \mathrm{~A}-$} & $20 \mathrm{R}-1,64-67$ & 763.1 & 4.3 \\
\hline $8 \mathrm{R}-1,26-28$ & 65.1 & 7.2 & $21 R-1,62-65$ & 772.8 & 4.5 \\
\hline $9 \mathrm{R}-1,37-39$ & 74.7 & 7.6 & $22 \mathrm{R}-1,52-55$ & 782.3 & 4.1 \\
\hline $9 \mathrm{R}-1,26-28$ & 74.6 & 8.0 & $23 \mathrm{R}-1,80-84$ & 792.3 & 4.3 \\
\hline \multirow{2}{*}{\multicolumn{3}{|c|}{$\begin{array}{l}139-855 \mathrm{D}- \\
5 \mathrm{R}-1,29-31\end{array}$}} & $\begin{array}{l}24 \mathrm{R}-1,112-115 \\
24 \mathrm{R}-2,100-103\end{array}$ & $\begin{array}{l}802.3 \\
803.7\end{array}$ & $\begin{array}{l}4.9 \\
4.5\end{array}$ \\
\hline & 108.8 & 7.0 & $26 \mathrm{R}-1,16-19$ & 820.5 & 4.7 \\
\hline \multirow{2}{*}{\multicolumn{3}{|c|}{$\begin{array}{l}139-856 \mathrm{~A}- \\
13 \mathrm{X}-\mathrm{CC}, 11-16\end{array}$}} & $27 \mathrm{R}-1,96-98$ & 830.6 & 4.7 \\
\hline & 113.3 & 6.5 & $29 \mathrm{R}-1,145-148$ & 849.9 & 4.6 \\
\hline $14 \mathrm{X}-\mathrm{CC}, 3-7$ & 115.8 & 7.1 & $31 \mathrm{R}-1,68-70$ & 869.2 & 4.8 \\
\hline & 115.1 & 6.5 & $32 \mathrm{R}-1,60-65$ & 878.7 & 5.1 \\
\hline \multicolumn{3}{|l|}{ 139-856B- } & 33R-1. 75-79 & 888.6 & 4.3 \\
\hline $9 X-1.48$ & 62.3 & 9.2 & $35 \mathrm{R}-1,27-29$ & 907.5 & 4.2 \\
\hline & & 9.2 & $\begin{array}{l}50 R-1,13-15 \\
36 \mathrm{R}-1,67-69\end{array}$ & $\begin{array}{l}917.0 \\
917.6\end{array}$ & $\begin{array}{l}4.3 \\
4.6\end{array}$ \\
\hline $\begin{array}{l}139-857 \mathrm{C}- \\
59 \mathrm{R}-1,106-108\end{array}$ & \\
\hline $59 \mathrm{R}-2,138-139$ & $\begin{array}{l}472.2 \\
474.0\end{array}$ & $\begin{array}{l}5.3 \\
5.3\end{array}$ & $25 \mathrm{R}-1,111-113$ & 250.0 & 4.5 \\
\hline $59 \mathrm{R}-3,101-103$ & 475.0 & 5.2 & $26 \mathrm{R}-1,63-65$ & 259.2 & 5.2 \\
\hline $60 \mathrm{R}-1,13-15$ & 480.9 & 4.9 & $26 \mathrm{R}-1,98-100$ & 259.6 & 5.1 \\
\hline $62 \mathrm{R}-1,46-48$ & 500.5 & 4.6 & $27 \mathrm{R}-1,39-41$ & 268.2 & 5.4 \\
\hline $62 R-2,60-62$ & 502.1 & 4.5 & $28 \mathrm{R}-1,30-32$ & 277.8 & 5.0 \\
\hline $64 \mathrm{R}-1,63-66$ & 520.0 & 4.8 & $29 \mathrm{R}-1,9-11$ & 287.3 & 5.4 \\
\hline $64 \mathrm{R}-2,33-35$ & 521.2 & 4.6 & $29 \mathrm{R}-1,81-83$ & 288.0 & 4.9 \\
\hline $65 \mathrm{R}-1,15-17$ & 529.3 & 7.5 & $9 \mathrm{R}-\mathrm{CC}, 18-20$ & 94.4 & 7.1 \\
\hline $66 \mathrm{R}-1,15-17$ & 539.0 & 6.8 & $25 R-1,40-42$ & 249.3 & 6.2 \\
\hline $66 \mathrm{R}-1,25-27$ & 539.1 & 2.9 & $25 \mathrm{R}-1,118-119$ & 258.1 & 4.2 \\
\hline $66 \mathrm{R}-1,114-116$ & 539.9 & 4.5 & $26 \mathrm{R}-1,42-44$ & 259.0 & 5.4 \\
\hline $67 \mathrm{R}-1,55-57$ & 549.0 & 6.6 & $27 \mathrm{R}-1,42-43$ & 268.2 & 5.4 \\
\hline $68 \mathrm{R}-1,26-29$ & 558.3 & 3.2 & $29 \mathrm{R}-1,65-67$ & 287.9 & 4.9 \\
\hline \multirow{3}{*}{$\begin{array}{l}68 \mathrm{R}-1,108-111 \\
68 \mathrm{R}-2,11-13 \\
68 \mathrm{R}-2,144-146\end{array}$} & 559.1 & 4.7 & 139-858G- & & \\
\hline & 559.6 & 4.2 & 1R-1, 37-39 & 277.2 & 4.9 \\
\hline & 560.9 & 4.6 & $2 \mathrm{R}-1,53-55$ & 287.0 & $\begin{array}{l}4.9 \\
5.3\end{array}$ \\
\hline \multicolumn{3}{|l|}{ 139-857D- } & $3 \mathrm{R}-1,24-25$ & 296.3 & 4.8 \\
\hline IR- $1,2-4$ & 581.5 & 4.2 & $4 \mathrm{R}-1,26-28$ & 306.1 & 5.1 \\
\hline $1 \mathrm{R}-2,82-84$ & 583.8 & 4.0 & $4 \mathrm{R}-1,71-73$ & 306.5 & 5.5 \\
\hline $2 \mathrm{R}-1,73-75$ & 590.3 & 4.7 & $5 R-1,16-18$ & 315.6 & 5.8 \\
\hline $2 \mathrm{R}-1,77-79$ & 590.4 & 4.4 & $6 \mathrm{R}-1,29-32$ & 325.4 & 5.1 \\
\hline $3 R-2,67-69$ & 601.4 & 4.3 & $7 \mathrm{R}-1,33-35$ & 335.1 & 4.8 \\
\hline $3 R-2,94-96$ & 601.7 & 4.2 & $8 \mathrm{R}-1,36-38$ & 344.9 & 4.5 \\
\hline $4 \mathrm{R}-1,9-11$ & 609.0 & 4.3 & $10 \mathrm{R}-, 31-33$ & 365.2 & 4.9 \\
\hline $7 \mathrm{R}-1,16-18$ & 637.8 & 4.5 & $10 \mathrm{R}-1,104-106$ & 366.0 & 4.6 \\
\hline $4 \mathrm{R}-1,88-90$ & 609.8 & 4.3 & $11 \mathrm{R}-1,16-18$ & 374.5 & 5.6 \\
\hline $8 \mathrm{R}-1,73-75$ & 648.0 & 2.4 & $12 \mathrm{R}-1,48-50$ & 384.7 & 5.0 \\
\hline $15 R-1,58-60$ & 715.4 & 3.3 & $13 R-1,9-11$ & 394.0 & 5.0 \\
\hline $18 \mathrm{R}-1,55-58$ & 744.2 & 4.5 & $13 \mathrm{R}-1,25-27$ & 394.2 & 4.7 \\
\hline $18 \mathrm{R}-1,98-101$ & 744.6 & 4.3 & $14 \mathrm{R}-1,41-43$ & 404.0 & 5.2 \\
\hline \multirow[t]{2}{*}{$18 \mathrm{R}-2,84-87$} & 745.9 & 4.6 & $15 \mathrm{R}-1,31-33$ & 413.6 & 4.9 \\
\hline & & & $16 \mathrm{R}-1,77-79$ & 423.7 & 5.1 \\
\hline
\end{tabular}

is determined by the more reliable $[\mathrm{La} / \mathrm{Ce}]_{\mathrm{n}}$. The values for $\mathrm{Zr} / \mathrm{Nb}$ (22-40; Davis, Mottl, Fisher, et al., 1992) categorizes these as TMORBs $(=16<\mathrm{Zr} / \mathrm{Nb}<25)$ and $\mathrm{N}-$ MORBS $(\mathrm{Zr} / \mathrm{Nb}>25)$. The more reliable REE (below) categorize these as all N-MORBs. The data form a linear array in a plot of $\mathrm{Zr}$ vs. Ti (Fig. 3A).

The REE patterns (Fig. 4B) are typical of N-type MORB derived from depleted mantle in that they are light REE depleted and otherwise flat to slightly HREE-depleted (Fig. 4). Values for chondrite-normalized La/Sm $\left([\mathrm{La} / \mathrm{Sm}]_{\mathrm{n}}=0.54-0.66\right) ; \mathrm{La} / \mathrm{Ce}\left([\mathrm{La} / \mathrm{Ce}]_{\mathrm{n}}=0.76-0.82\right)$ and $\mathrm{Ce} / \mathrm{Yb}\left([\mathrm{Ce} / \mathrm{Yb}]_{\mathrm{n}}=0.76-0.89\right)$ confirm the depleted nature of their mantle source region (Fig. 3, Table 1, section B). A pronounced negative europium anomaly is evident in the most fractionated (highest REEs) sample, probably resulting from fractionation of plagioclase.

\section{Site 856, Holes A and B}

\section{Setting}

At Site 856, a series of drillholes was located across a topographic high referred to as "Bent Hill," which is about $60 \mathrm{~m}$ high and about $500 \mathrm{~m}$ in diameter. In Holes $856 \mathrm{G}$ and $856 \mathrm{H}, 65 \mathrm{~m}$ and $95 \mathrm{~m}$ of massive sulfide, respectively, were cored. Small quantities of mafic igneous rock were drilled at the bottom of Holes $856 \mathrm{~A}$ and $856 \mathrm{~B}$ and from a 5-8-m-thick sill that was drilled through completely in Hole
Table 3. Microprobe analyses of olivine phenocryst compositions, Leg 139, Sites 855 and 856.

\begin{tabular}{|c|c|c|c|c|c|c|c|}
\hline & $1^{\mathrm{a}}$ & $2 b$ & $3^{\mathrm{c}}$ & $4^{d}$ & $5^{e}$ & $6^{f}$ & $7^{8}$ \\
\hline $\mathrm{SiO}_{2}$ & 38.88 & 38.26 & 39.76 & 40.31 & 39.81 & 40.83 & 40.73 \\
\hline & 0.08 & 0.01 & 0.03 & 0.04 & 0.08 & 0.06 & 0.07 \\
\hline $\mathrm{Cr}_{2} \mathrm{O}_{3}$ & 0.00 & 0.01 & 0.01 & 0.03 & 0.06 & 0.04 & 0.06 \\
\hline $\mathrm{MgO}^{3}$ & 43.72 & 39.26 & 44.57 & 48.23 & 46.61 & 48.89 & 48.56 \\
\hline $\mathrm{CaO}$ & 0.33 & 0.29 & 0.33 & 0.29 & 0.36 & 0.28 & 0.33 \\
\hline $\mathrm{MnO}$ & 0.22 & 0.36 & 0.25 & 0.19 & 0.15 & 0.13 & 0.19 \\
\hline $\mathrm{FeO}$ & 16.26 & 21.13 & 15.37 & 10.90 & 12.46 & 10.43 & 10.03 \\
\hline Total & 99.50 & 99.33 & 100.32 & 99.99 & 99.53 & 100.65 & 99.95 \\
\hline $\mathrm{Si}$ & 0.992 & 0.998 & 0.998 & 0.994 & 0.994 & 0.997 & 1.000 \\
\hline Al & 0.002 & 0.000 & 0.001 & 0.001 & 0.002 & 0.002 & 0.002 \\
\hline $\mathrm{Cr}$ & 0.000 & 0.000 & 0.000 & 0.001 & 0.001 & 0.001 & 0.001 \\
\hline $\mathrm{Mg}$ & 1.674 & 1.526 & 1.667 & 1.773 & 1.7 & 1.780 & 1.777 \\
\hline $\mathrm{Ca}$ & 0.009 & 0.008 & 0.009 & 0.008 & 0.010 & 0.007 & 0.009 \\
\hline Mn & 0.005 & 0.008 & 0.005 & 0.004 & 0.003 & 0.003 & 0.004 \\
\hline $\mathrm{Fe}$ & 0.349 & 0.461 & 0.323 & 0.225 & 0.260 & 0.213 & 0.206 \\
\hline Catsum & 3.032 & 3.002 & 3.002 & 3.005 & 3.005 & 3.002 & 2.998 \\
\hline Fo & 82.74 & 76.81 & 83.93 & 88.91 & 87.25 & 89.53 & 89.83 \\
\hline $\mathrm{Fa}$ & 17.26 & 23.19 & 16.24 & 11.27 & 13.09 & 10.71 & 10.41 \\
\hline \multicolumn{8}{|c|}{$\begin{array}{l}\text { a } 139-855 \mathrm{~A}-8 \mathrm{R}-1,21-23 \mathrm{~cm} \text {, large euhedral grain. } \\
\text { b } 139-855 \mathrm{~A}-8 \mathrm{R}-1,35-37 \mathrm{~cm} \text {, rim of zoned olivine. } \\
\text { c } 139-855 \mathrm{D}-5 \mathrm{R}-1,15-17 \mathrm{~cm} \text {, core of large grain. } \\
\text { d } 139-856 \mathrm{~A}-14 \mathrm{X}-1,23-26 \mathrm{~cm} \text {, core of large grain. } \\
\text { e } 139-856 \mathrm{~A}-14 \mathrm{X}-1,23-26 \mathrm{~cm} \text {, rim of same large grain as previous } \\
\text { f } 139-856 \mathrm{~A}-14 \mathrm{X}-1,85-87 \mathrm{~cm} \text {, core of large grain. } \\
\text { g } 139-856 \mathrm{~B}-8 \mathrm{H}-\mathrm{CC}, 1-3 \mathrm{~cm} \text {, core of large grain. }\end{array}$} \\
\hline
\end{tabular}

856B (Davis, Mottl, Fisher, et al., 1992). All the samples are inferred to be from sills based on the nature of the chilled contacts and rapid increase in grain size from the margins (Davis, Mottl, Fisher, et al., 1992). The margins of the sills have thin glassy rims which are typically replaced by chlorite and quartz. Some of the contacts are evidenced only by small fragments of bleached basalt with coatings of baked sediment. Most of the igneous rocks recovered, however, are holocrystalline with a microcrystalline to fine-grained groundmass of variolitic plagioclase and clinopyroxene. The mesostasis in a few samples is replaced by small quantities of greenschist-grade minerals including chlorite, epidote, and actinolite.

\section{Petrography and Mineral Chemistry}

Olivine is present as phenocrysts in all samples, both as large subhedral crystals and small rounded crystals. The large crystals tend to be broken and replaced along fractures, or to contain groundmass minerals along fractures. The olivine crystals are highly magnesian $\left(\mathrm{Fo}_{88-90}\right.$; Table 3$)$ and are typically unzoned. They frequently occur in megacrystic aggregates with euhedral spinel, an association characteristic of crystal accumulates. The olivine phenocrysts comprise $2 \%-8 \%$ of the rock.

Spinel is present as brownish-red to deep red euhedral crystals that are associated with the large olivines and commonly occur as inclusions within the olivines. The spinels rarely contain inclusions of smectite or chlorite, presumably as replacements of glass. The spinels are highly magnesian (Table 6) and are typically unzoned. A few crystals do have a $\mathrm{Cr}$-rich rim, however, which is also conspicuous by having a deeper color. The $\mathrm{Mg}$ numbers of the spinels vary from 0.5 to 0.9 and the $\mathrm{Cr}$ numbers vary from 0.3 to 0.5 (Figs. 5A, 5B).

In addition to the $\mathrm{Cr}-\mathrm{Mg}-\mathrm{Al}$ spinels, the principal oxide phase is titanomagnetite (Table 7, section A). These grains are generally intersertal to plagioclase and ferromagnesian grains and are typically about $0.5 \mathrm{~mm}$ in width. In some areas titanomagnetite forms distinct rims on the Cr-rich spinels, indicating that it formed slightly later than spinel. Isolated grains of titanomagnetite have an average composition of $\left(\mathrm{Fe}^{3+} 0.78 \mathrm{Fe}^{2+} 1.51 \mathrm{Ti}_{0.56} \mathrm{~V}_{0.03} \mathrm{Mn}_{0.05}\right) \mathrm{O}_{4}$. They are not altered, and appear to be unzoned. Where titanomagnetite either rims or is intergrown with spinel it has a higher $\mathrm{Cr}$ content than those grains that formed independently of spinel. In Sample 139-856A-14X, 90-92 cm, for example, titanomagnetite surrounding spinel contains 9.5 weight percent (wt\%) $\mathrm{Cr}_{2} \mathrm{O}_{3}$ and $2.98(\mathrm{wt} \%) \mathrm{V}_{2} \mathrm{O}_{5}$. 
Table 4. Plagioclase compositions, Leg 139, Sites 855-858, representative analyses of fresh and unaltered phases.

\begin{tabular}{|c|c|c|c|c|c|c|c|c|c|c|c|c|c|c|c|c|c|c|}
\hline & $1^{a}$ & $2^{b}$ & $3^{c}$ & $4^{d}$ & $5^{e}$ & $6^{f}$ & $7^{8}$ & $8^{b}$ & $9^{i}$ & $10^{j}$ & $11^{k}$ & $12^{1}$ & $13^{\mathrm{m}}$ & $14^{n}$ & $15^{\circ}$ & $16^{p}$ & $17^{4}$ & $18^{r}$ \\
\hline $\mathrm{SiO}_{2}$ & 46.25 & 47.63 & 50.31 & 49.70 & 51.65 & 50.26 & 51.42 & 51.23 & 52.34 & 54.57 & 55.97 & 46.00 & 49.14 & 51.41 & 56.68 & 51.99 & 55.49 & 67.81 \\
\hline & 34.31 & 32.99 & 32.60 & 32.06 & 29.81 & 32.10 & 30.85 & 31.24 & 29.36 & 29.16 & 28.07 & 34.85 & 32.64 & 30.64 & 26.18 & 30.20 & 27.86 & 21.05 \\
\hline $\mathrm{Fe}_{2} \mathrm{O}_{3}{ }^{*}$ & 0.53 & 0.41 & 0.58 & 0.65 & 1.01 & 0.46 & 0.67 & 0.48 & 0.97 & 0.87 & 1.15 & 0.41 & 0.69 & 0.75 & 0.98 & 0.73 & 1.19 & 0.03 \\
\hline $\mathrm{CaO}$ & 17.57 & 16.07 & 15.79 & 15.59 & 13.27 & 15.09 & 14.02 & 14.92 & 14.00 & 11.96 & 10.64 & 18.62 & 15.92 & 13.23 & 9.07 & 13.16 & 10.47 & 1.41 \\
\hline $\mathrm{Na}_{2} \mathrm{O}$ & 1.61 & 2.17 & 2.50 & 2.58 & 3.50 & 2.69 & 3.27 & 2.98 & 3.48 & 4.36 & 5.12 & 1.04 & 2.36 & 3.63 & 6.08 & 3.58 & 5.07 & 9.63 \\
\hline $\mathrm{K}_{2} \mathrm{O}$ & 0.00 & 0.02 & 0.03 & 0.00 & 0.01 & 0.00 & 0.01 & 0.02 & 0.03 & 0.06 & 0.06 & 0.00 & 0.01 & 0.04 & 0.12 & 0.03 & 0.08 & 0.09 \\
\hline Total & 100.27 & 99.29 & 101.80 & 100.59 & 99.25 & 100.61 & 100.23 & 100.86 & 100.18 & 100.98 & 101.01 & 100.92 & 100.76 & 99.70 & 99.10 & 99.67 & 100.14 & 100.01 \\
\hline $\mathrm{Si}$ & 2.125 & 2.194 & 2.258 & 2.259 & 2.348 & 2.277 & 2.333 & 2.314 & 2.378 & 2.442 & 2.498 & 2.105 & 2.232 & 2.338 & 2.570 & 2.366 & 2.498 & 2.952 \\
\hline $\mathrm{Al}$ & 1.858 & 1.791 & 1.724 & 1.717 & 1.597 & 1.714 & 1.650 & 1.663 & 1.572 & 1.538 & 1.477 & 1.877 & 1.748 & 1.643 & 1.399 & 1.620 & 1.478 & 1.080 \\
\hline $\mathrm{Fe}$ & 0.018 & 0.016 & 0.019 & 0.022 & 0.038 & 0.016 & 0.023 & 0.016 & 0.033 & 0.029 & 0.039 & 0.014 & 0.024 & 0.029 & 0.033 & 0.025 & 0.040 & 0.001 \\
\hline $\mathrm{Ca}$ & 0.865 & 0.793 & 0.759 & 0.759 & 0.646 & 0.733 & 0.681 & 0.722 & 0.682 & 0.574 & 0.509 & 0.912 & 0.775 & 0.645 & 0.441 & 0.642 & 0.505 & 0.066 \\
\hline $\mathrm{Na}$ & 0.144 & 0.194 & 0.218 & 0.227 & 0.309 & 0.236 & 0.288 & 0.261 & 0.307 & 0.378 & 0.443 & 0.092 & 0.208 & 0.320 & 0.534 & 0.316 & 0.442 & 0.813 \\
\hline K & 0.000 & 0.001 & 0.002 & 0.000 & 0.001 & 0.000 & 0.000 & 0.001 & 0.002 & 0.004 & 0.004 & 0.000 & 0.001 & 0.003 & 0.007 & 0.002 & 0.004 & 0.005 \\
\hline Catsum & 5.009 & 4.989 & 4.980 & 4.985 & 4.938 & 4.976 & 4.975 & 4.977 & 4.974 & 4.965 & 4.968 & 5.000 & 4.987 & 4.976 & 4.984 & 4.970 & 4.967 & 4.916 \\
\hline $\mathrm{Ab}$ & 14.3 & 19.63 & 22.26 & 23.02 & 32.30 & 24.38 & 29.68 & 73.40 & 68.84 & 39.57 & 46.36 & 9.15 & 21.13 & 33.08 & 54,42 & 32.91 & 46.48 & 92.03 \\
\hline An & 85.7 & 80.35 & 77.56 & 76.95 & 67.64 & 75.61 & 70.28 & 26.50 & 30.98 & 60.05 & 53.27 & 90.84 & 78.79 & 66.66 & 44.90 & 66.92 & 53.06 & 7.42 \\
\hline Or & 0.00 & 0.12 & 0.18 & 0.02 & 0.06 & 0.01 & 0.04 & 0.10 & 0.18 & 0.38 & 0.36 & 0.01 & 0.08 & 0.26 & 0.69 & 0.17 & 0.46 & 0.55 \\
\hline
\end{tabular}

Note: $\mathrm{Fe}_{2} \mathrm{O}_{3}{ }^{*}=$ total $\mathrm{Fe}$ expressed as $\mathrm{Fe}_{2} \mathrm{O}_{3}$.

a 139-855A-8R-1, 21-23, $2 \mathrm{~cm}$, core of zoned plagioclase.

b $139-855 \mathrm{~A}-8 \mathrm{R}-1,18-19,2 \mathrm{~cm}$, small phenocryst intergrown with pryroxene.

c 139-855A-8R-1, 18-19,2 cm, small phenocrysts intergrown with $\mathrm{Cr}$-rich pyroxene.

d 139-855-5R1, 15-17 cm, core, large phenocryst.

e 139-855-5R-1, 15-17 cm, rim, large phenocryst.

f $139-856 \mathrm{~B}-10 \mathrm{H}, 74-77 \mathrm{~cm}$, rim of thin microphenocryst.

g 139-856B-10H, 74-77 cm, skeletal plagioclase.

h $139-856 \mathrm{~A}-14 \mathrm{X}-\mathrm{CC}, 20-22 \mathrm{~cm}$, core of euphedral lath.

139-856A-14X-CC, 20-22 cm, rim of euhedral lath.

j39-857D-17R-3, 89-91 cm, rim of altered grain.

k $139-857 \mathrm{D}-17 \mathrm{R}-3,89-91 \mathrm{~cm}$, rim of altered grain.

1 $139-857 \mathrm{D}-12 \mathrm{R}-1,51-53 \mathrm{~cm}$, core of xenocryst.

$\mathrm{m}$ 139-857D-12R-1, 51-53 cm, small euhedral phenocryst.

n $139-857 \mathrm{C}-59 \mathrm{R}-1,145-147 \mathrm{~cm}$, grain poikilitically intergrown with pyroxene.

${ }^{\circ} 139-857 \mathrm{C}-59 \mathrm{R}-1,145-147 \mathrm{~cm}$, rim of altered grain.

p 139-858-G-1R-1, 27-29 cm, core of thin lath.

q $139-858 \mathrm{G}-1 \mathrm{R}-1,27-29 \mathrm{~cm}$, rim of thin lath.

r $139-858 \mathrm{G}-16 \mathrm{R}-1,47-49 \mathrm{~cm}$, altered patch in phenocryst.

All of the rocks contain plagioclase both as a groundmass phase and as phenocrysts. There is a continuous gradient in the size of the plagioclase crystals from large subhedral or embayed crystals to small lathlike crystals intergrown with clinopyroxene. The plagioclase is rarely replaced by pale aluminous epidote, but is more typically fresh. Most plagioclase is moderately calcic $\left(\mathrm{An}_{74-79}\right)$ but more sodic compositions are found as groundmass phases or rims on larger crystals $\left(\mathrm{An}_{64-70}\right)$.

Clinopyroxene is never observed as a phenocryst phase in these samples as was observed at Site 855. It is present only in the groundmass in variolitic bundles or small needle-like aggregates.

Sulfides in the least-altered samples examined (139-856A-14X-1, $7-9 \mathrm{~cm}, 86-88 \mathrm{~cm}, 90-92 \mathrm{~cm}$ ) occur as polysulfide aggregates. These aggregates occur primarily as inclusions in plagioclase phenocrysts, but also occur as irregular to spherical blebs in the mesostasis. The latter resemble classic "immiscible sulfide" droplets common to all magmatic sulfide bodies. The inclusions and bleb aggregates are usually about 50 microns in diameter. The sulfide aggregates are composed primarily of pyrrhotite, with exsolved lamellae and blebs of pentlandite and minor chalcopyrite. Microprobe analyses of these sulfides (Table 8 ) indicate that the pyrrhotite is nickel-rich. Analyses of one such bleb in Sample 139-856 A-14x-1,90-92 cm illustrates that the exsolution of pentlandite is not complete, as the adjacent pyrrhotite has nickel contents varying from $1.08 \%$ to $4.84 \%$. The most Ni-rich pyrrhotite contains $3.64 \%$ copper, indicating incomplete subsolidus exsolution of copper as well as nickel from this portion of the sulfide bleb. The most Fe-rich pentlandite corresponds to the most Ni-rich pyrrhotite, indicating that the system has remained closed with respect to sulfur. This suggests that seawater did not penetrate into the center of these thin intrusions as would be anticipated with hydrothermal cooling of the sills. Equilibrium exsolution was not reached, as is indicated by the highly variable amount of $\mathrm{Ni}$ and $\mathrm{Cu}$ in the probe data. As these intrusions were emplaced close to the seafloor (ca. $115 \mathrm{mbsf}$ ), heat loss from them was rapid and complete exsolution of pentlandite and copper minerals was prevented. The most-altered samples from this site (Samples 139-856B-10H-1, 93-95 cm and 10H-2, 2-9 cm; see discussion of petrochemical data, below) come from the shallowest of these intrusions. Here, only pyrite is present, as subhedral to euhedral grains. Its nickel contents are comparable with those of the primary pyrrhotite and much higher than the nickel contents of hydrothermal pyrite (Franklin et al., unpubl. data).

\section{Major Element Composition}

The new data provided as part of this study confirm the shipboard observations (Davis, Mottl, Fisher, et al., 1992) that these rocks are similar to the most primitive rocks of the northern Juan de Fuca, the olivine-phyric flows of West Ridge (Van Wagoner and Leybourne, 1991). All of these intrusions have been hydrated, and all may have been somewhat altered. However, the silicate phenocrysts are predominantly fresh and oxide and sulfide phases appear very fresh. An exception is Sample 139-856B-10H-1, 93-95 cm, from the margin of the sill drilled through in Hole 856A, which is highly altered. It contains an unusually high potash content, high titania and alumina, all characteristics of the extremely leached basalt-sediment chilled contacts observed in Site 856 and Site 857. This sample has been eliminated from the subsequent plots. In the fresh samples, the $\mathrm{SiO}_{2}$, $\mathrm{TiO}_{2}, \mathrm{FeOT}$ and $\mathrm{P}_{2} \mathrm{O}_{5}$ contents are all lower than in the samples from the other sites (Table 1; Fig. 2), due in part to dilution by olivine megacrysts. However, samples from Site 856 are slightly more aluminous and have much higher $\mathrm{Mg}$ numbers than samples from the other sites. Their Mg\# is 73, distinctly higher than that for samples from the Southern Juan de Fuca, Endeavour (Karsten et al., 1990), Heck and Heckle seamounts (Leybourne and Van Wagoner, 1991), West Valley (Van Wagoner and Leybourne, 1991), or Explorer Ridge 
Table 5. Microprobe analyses of clinopyroxene compositions, Leg 139, Sites 855, 857, and 858 .

\begin{tabular}{|c|c|c|c|c|c|c|c|c|c|c|c|c|c|c|}
\hline & $1^{2}$ & $2^{b}$ & $3^{c}$ & $4^{d}$ & $5^{e}$ & $6^{f}$ & $7^{8}$ & $8^{h}$ & $9^{i}$ & $10^{i}$ & $11^{\mathrm{k}}$ & $12^{1}$ & $13^{m}$ & $14^{n}$ \\
\hline $\mathrm{SiO}_{2}$ & 50.480 & 49.830 & 50.020 & 51.530 & 52.180 & 50.080 & 51.800 & 45.730 & 50.940 & 51.100 & 50.530 & 50.420 & 52.700 & 50.37 \\
\hline $\mathrm{TiO}_{2}$ & 0.500 & 1.230 & 1.100 & 0.990 & 0.660 & 1.150 & 0.680 & 3.540 & 0.850 & 1.100 & 1.200 & 1.280 & 0.580 & 1.21 \\
\hline $\mathrm{Al}_{2} \mathrm{O}_{3}$ & 3.960 & 4.150 & 4.190 & 3.900 & 2.650 & 4.600 & 3.950 & 6.090 & 1.860 & 3.280 & 2.780 & 3.900 & 1.810 & 1.83 \\
\hline $\mathrm{Fe}_{2} \mathrm{O}_{3}$ & 2.216 & 1.869 & 1.939 & 0.627 & 1.115 & 1.397 & 0.451 & 2.274 & 0.625 & 1.000 & 1.817 & 1.443 & 0.000 & 1.19 \\
\hline $\mathrm{FeO}$ & 2.886 & 5.918 & 5.826 & 5.426 & 4.927 & 4.593 & 4.704 & 9.904 & 13.268 & 8.190 & 9.205 & 6.752 & 7.620 & 14.13 \\
\hline $\mathrm{MnO}$ & 0.240 & 0.190 & 0.170 & 0.150 & 0.230 & 0.130 & 0.180 & 0.220 & 0.440 & 0.250 & 0.290 & 0.200 & 0.280 & 0.41 \\
\hline $\mathrm{MgO}$ & 17.020 & 16.070 & 16.500 & 17.310 & 17.640 & 16.710 & 16.830 & 10.880 & 13.100 & 15.910 & 15.260 & 15.520 & 16.770 & 12.55 \\
\hline $\mathrm{CaO}$ & 20.370 & 19.270 & 18.810 & 19.090 & 19.730 & 19.530 & 20.440 & 20.570 & 18.200 & 18.240 & 18.240 & 19.890 & 18.970 & 18.00 \\
\hline $\mathrm{Na}_{2} \mathrm{O}$ & 0.270 & 0.270 & 0.280 & 0.350 & 0.240 & 0.300 & 0.320 & 0.430 & 0.280 & 0.280 & 0.310 & 0.290 & 0.210 & 0.29 \\
\hline $\mathrm{Cr}_{2} \mathrm{O}_{3}$ & 1.430 & 0.590 & 0.740 & 0.240 & 0.220 & 0.920 & 1.520 & 0.100 & 0.000 & 0.160 & 0.070 & 0.360 & 0.410 & 0.00 \\
\hline Sum & 99.372 & 99.387 & 99.575 & 99.613 & 99.592 & 99.410 & 100.875 & 99.738 & 99.563 & 99.510 & 99.702 & 100.055 & 99.350 & 99.98 \\
\hline $\mathrm{Si}$ & .858 & 1.850 & 1.850 & .889 & 1.914 & 1.846 & 1.880 & 1.743 & 1.935 & 1.892 & 1.890 & 1.864 & 1.951 & 1.918 \\
\hline $\mathrm{Ti}$ & 0.014 & 0.034 & 0.031 & 0.027 & 0.018 & 0.032 & 0.019 & 0.101 & 0.014 & 0.031 & 0.034 & 0.036 & 0.016 & 0.035 \\
\hline $\mathrm{Al}$ & 0.172 & 0.182 & 0.183 & 0.169 & 0.115 & 0.200 & 0.169 & 0.274 & 0.083 & 0.1 & 0.123 & 70 & 0.079 & 0.082 \\
\hline $\mathrm{Fe}_{3}$ & 0.061 & 0.052 & 0.054 & 0.017 & 0.031 & 0.039 & 0.012 & 0.065 & 0.018 & 0.028 & 0.051 & 0.040 & 0.000 & 0.034 \\
\hline $\mathrm{Fe}_{2}$ & 0.089 & 0.184 & 0.180 & 0.166 & 0.151 & 0.142 & 0.143 & 0.316 & 0.422 & 0.254 & 0.288 & 0.209 & 0.236 & 0.450 \\
\hline $\mathrm{Mn}$ & 0.007 & 0.006 & 0.005 & 0.005 & 0.007 & 0.004 & 0.006 & 0.007 & 0.104 & 0.008 & 0.009 & 0.006 & 0.009 & 0.013 \\
\hline $\mathrm{Mg}$ & 0.934 & 0.889 & 0.910 & 0.946 & 0.965 & 0.918 & 0.910 & 0.618 & 0.742 & 0.878 & 0.850 & 0.855 & 0.925 & 0.712 \\
\hline $\mathrm{Ca}$ & 0.804 & 0.766 & 0.746 & 0.750 & 0.776 & 0.771 & 0.795 & 0.840 & 0.741 & 0.743 & 0.731 & 0.788 & 0.752 & 0.734 \\
\hline $\mathrm{Na}$ & 0.019 & 0.019 & 0.020 & 0.025 & 0.017 & 0.021 & 0.023 & 0.032 & 0.021 & 0.020 & 0.022 & 0.021 & 0.015 & 0.021 \\
\hline $\mathrm{Cr}$ & 0.042 & 0.017 & 0.022 & 0.007 & 0.006 & 0.027 & 0.044 & 0.003 & 0.000 & 0.005 & 0.002 & 0.011 & 0.012 & 0.000 \\
\hline Catsum & 4.000 & 3.999 & 4.001 & 4.001 & 4.000 & 4.000 & 4.001 & 3.999 & 4.080 & 4.002 & 4.000 & 4.000 & 3.995 & 3.999 \\
\hline Wo & 44.00 & & 40.6 & & & & & & & & & & & 38.72 \\
\hline En & .53 & & 49.56 & & 51. & 50.14 & & & & & & & & \\
\hline Fs & 4.87 & 9.99 & 9.82 & 8.93 & 7.99 & 7.73 & 7.73 & 17.80 & 22.14 & 13.53 & 15.40 & 11.27 & 12.33 & 23.73 \\
\hline
\end{tabular}

139-855A-8R-1, 21-23 cm, megacryst in glass host.

b $139-855 \mathrm{~A}-8 \mathrm{R}-1,18-19 \mathrm{~cm}$, core of pyroxene phenocryst.

c 139-855A-8R-1, 18-19 cm, rim of zoned phenocrysts.

d $139-857 \mathrm{C}-59 \mathrm{R}-1,16-18 \mathrm{~cm}$, phenocryst.

c $139-857 \mathrm{C}-60 \mathrm{R}-2,17-19 \mathrm{~cm}$, core of reversely zoned pyroxene.

f $139-857 \mathrm{C}-60 \mathrm{R}-2,17-19 \mathrm{~cm}$, rim of reversely zoned pyroxene.

g 139-857C-59R-3, 140-142 cm, cr-rich core of pyroxene.

h $139-857 \mathrm{C}-66 \mathrm{R}-1,108-110 \mathrm{~cm}$, rim of brownish pyroxene.

i 139-857D-17R-3, 89-91 cm, core of anhedral pyroxene.

j $139-857 \mathrm{D}-17 \mathrm{R}-3,89-91 \mathrm{~cm}$, rimof anhedral pyroxene.

k 139-857D-35R-1, 87-90 cm, small barrel-shaped crystal.

139-857D-35R-1, 87-90 cm, rim of zoned pyroxene.

m 139-857D-35R-1, 87-90 cm, poikilitic intergrowth.

n $139-857 \mathrm{D}-35 \mathrm{R}-1,87-90 \mathrm{~cm}$, poikilitic intergrowth.

(Cousens et al., 1984) areas. The Mg\# calculated on the basis on the whole-rock chemistry is biased by the accumulation of phenocrysts compared to the chemistry of the original fresh glass. The Mg\# based on the chromian spinel compositions (see Discussion), however, is not biased in this way and still distinguishes these magmas as extreme compositions, although similar to the most primitive compositions from West Ridge, West Valley South or the Heck Seamounts.

\section{Minor and Trace Element Composition}

These samples are more chromian and nickel rich than other mafic rocks in the Middle Valley area, reflecting the abundant spinel and primary sulfide accumulations noted above. The sulfur content of the samples from Site 856 are reasonably uniform (330 to $1400 \mathrm{ppm}$ ). Nickel, copper, and zinc are within the range of normal basaltic melts with averages of 220,77 , and $68 \mathrm{ppm}$, respectively. The sulfur content of the samples ( $1400 \mathrm{ppm}$ maximum) is only slightly higher than that predicted for sulfur-saturated melts of composition similar to Site 856 samples (Mathez, 1980), indicating that sulfur has not been added during alteration. Furthermore, the $\mathrm{MgO}$ contents of the unaltered samples correlate well with their $\mathrm{Ni}$ contents, i.e., with modal olivine. $\mathrm{Had} \mathrm{Mg}$ been added from seawater through alteration, this correlation would be nonexistent. The replacement of olivine by talc and magnetite appears to be a static hydration not associated with substantial change in chemistry. The replacement of oxides (e.g., spinel) by sulfide was only observed in the narrow, highly-altered contact zone with sediments.

The Site 856 samples contain lower contents of most of the incompatible elements than the other sites, partially due to dilution by crystal accumulation (Figs. 3 and 4). All of the samples are homogeneous, forming tight clusters on most of the plots. On the $\mathrm{Zr} v$ s. $\mathrm{TiO}_{2}$ plot, they fall at the low $\mathrm{Zr}$ and low $\mathrm{TiO}_{2}$ end of the plot, similar to primitive basalts, and form a linear array distinct from the other sites. Their $\mathrm{Zr} / \mathrm{Nb}$ values (22-50) (Davis, Mottl, Fisher, et al., 1992) classify them as T-MORB to N-MORB but the low values of $\mathrm{Nb}$ make this classification unreliable. Values for $[\mathrm{La} / \mathrm{Sm}]_{\mathrm{n}}(0.28-0.29),[\mathrm{La} / \mathrm{Ce}]_{\mathrm{n}}(0.65-$ $0.70)$ and $[\mathrm{Ce} / \mathrm{Yb}]_{\mathrm{n}}(0.37-0.39)$ are significantly lower than those for Site 855 (Fig. 3) and classify them more reliably as N-MORB. The only exception is the slightly altered Sample 139-856B-10H-1R, 64 $67 \mathrm{~cm}$, which has values falling between those of the adjacent, highly altered sample and the remaining analyses. Thus, the contact alteration may have produced a spuriously high $[\mathrm{La} / \mathrm{Ce}]_{\mathrm{n}}$ value (or may have mixed in some sediment, M. Leybourne, pers. comm., 1993). Their chondrite-normalized REE patterns indicate that they are quite homogeneous and typified by LREE depletion and flat HREE (Fig. 4). The REE patterns are similar to those for the Heck and Heckle seamounts to the west of Middle Valley and Endeavour Ridge (Leybourne and Van Wagoner, 1991) and the depleted magmas of West Ridge (Van Wagoner and Leybourne, 1991), but are quite distinct from LREEenriched patterns for samples from Endeavour Ridge (Karsten et al., 1990) or West Valley (Van Wagoner and Leybourne, 1991).

\section{Site 857, Holes C and D}

\section{Setting}

Sites 857 and 858 are located $6 \mathrm{~km}$ west of the eastern boundary fault and $6 \mathrm{~km}$ west of the Middle Valley spreading axis (Fig. 1). The sites are $1.6 \mathrm{~km}$ apart along a north-south line and lie within a $15-\mathrm{km}-$ long thermal anomaly that parallels the rift within which heat flow exceeds $0.8 \mathrm{Wm}^{-2}$ (Davis, Mottl, Fisher, et al., 1992). Igneous rock recovered at Site 857 is from a series of variably metamorphosed 1- to 

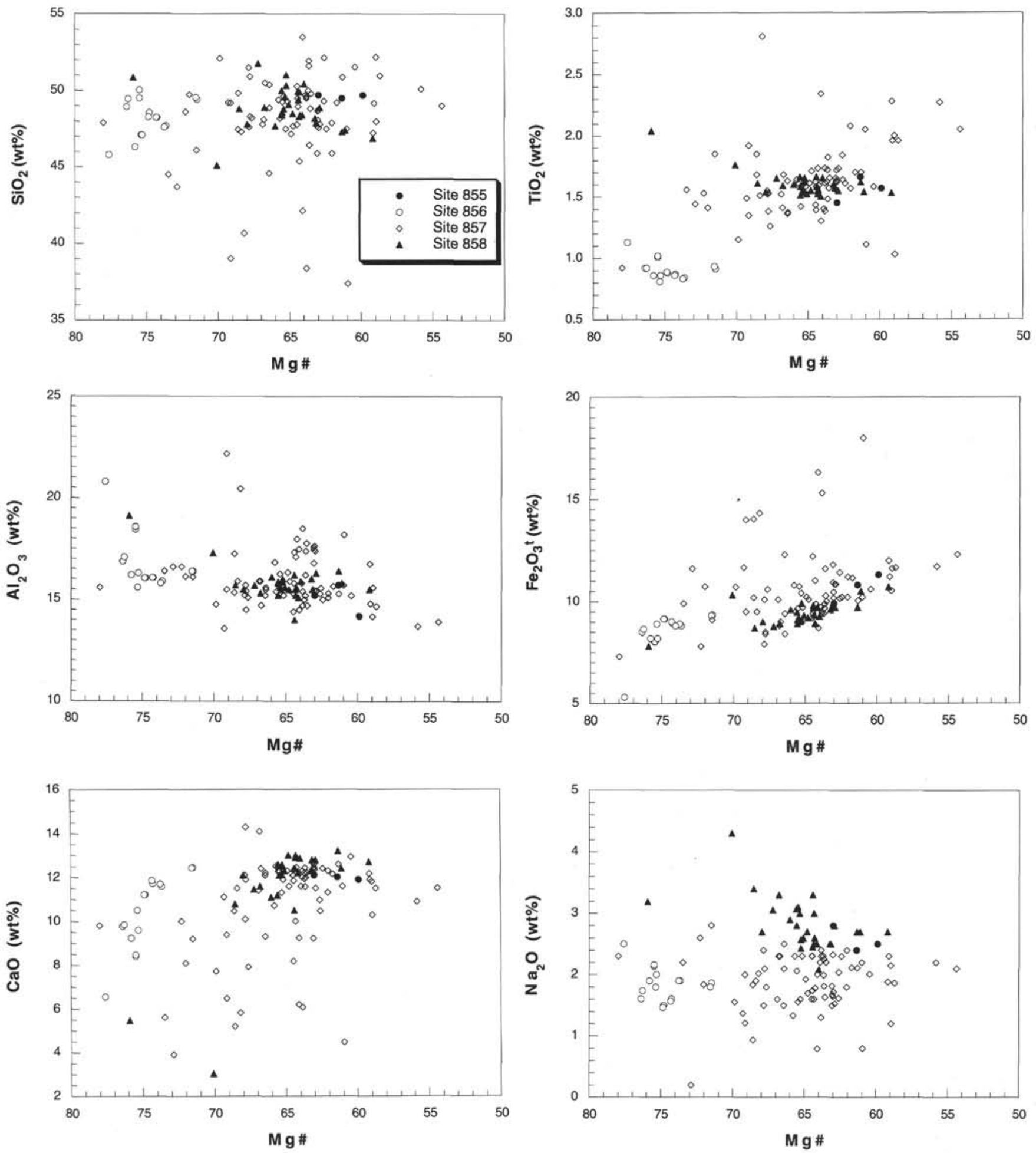

Figure 2. Major element chemistry for all sites, Leg 139.

25-m-thick mafic sills interlayered with altered and indurated sediment. For many of the intrusive units, a fine-grained chilled margin and coarse-grained interior could be readily identified in the drillcore. This, combined with the resistivity data collected by shipboard logging, indicates relatively complete sampling across individual sills. The interiors of the larger sills are extremely coarse grained and composed of poikilitically intergrown plagioclase and clinopyroxene with ilmenite or magnetite and fine-grained mesostasis. Extreme variability of texture and crystal size is a conspicuous characteristic of the sills and results from variations in cooling rate from the sill margins to the interiors. This variability is mirrored in clinopyroxene compositions described below. Comparison between the intervals of recovered igneous rock and levels of high resistivity logged in Hole 857C suggest recovery modestly estimated at over $50 \%$. Similar compari- 

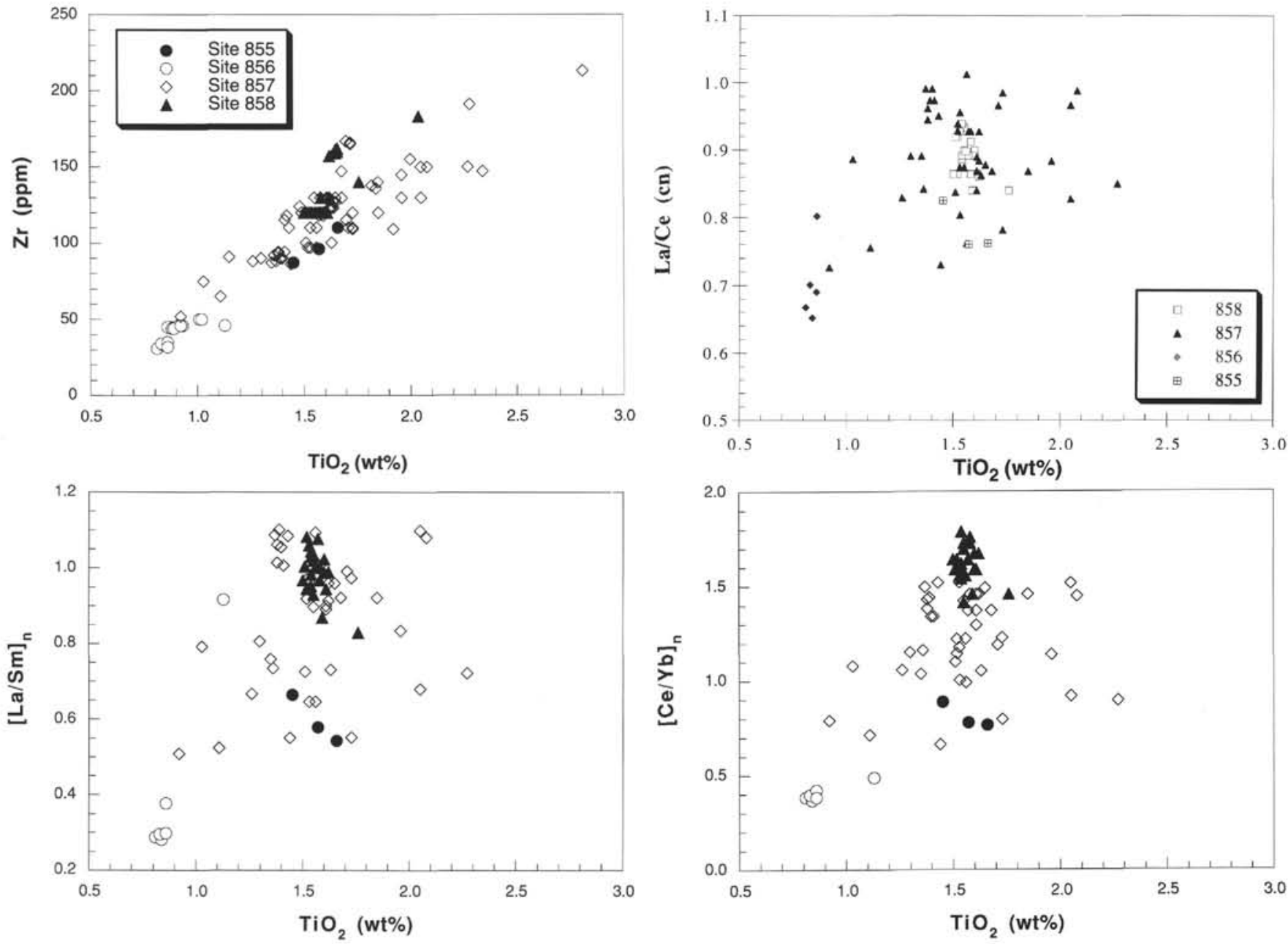

Figure 3. Trace element chemistry for all sites, Leg 139.

sons for Hole 857D suggests a slightly lower, but still high recovery of the igneous units (Davis, Mottl, Fisher, et al., 1992).

\section{Site 857 Lithostratigraphy}

Both Holes 857C and 857D were logged, and the resistivity log proved useful in discriminating sills vs. sediments (Davis, Mottl, Fisher, et al., 1992, pp. 364-365). The log from Hole 857D (which includes most of the sill horizon from Hole 857C) suggested that there were 32 distinct sills between 465 and 934 mbsf for a combined thickness of $165 \mathrm{~m}$ of igneous rock. Detailed lithostratigraphy from Davis, Mottl, Fisher, et al. (1992) is expanded here with new mineral data and is summarized in Table 9. Igneous rock was first encountered in Core 857C-59R (Unit 1), the top of which is fine-grained diabase with plagioclase and pyroxene phenocrysts and megacrysts that increase in size and compositional zoning (plagioclase $=A n_{56-73}$ ) with depth. In Sections 139-857C-59R-2 and 857C-59R-3 the ophitic texture is extremely coarse-grained (plagioclase $=\mathrm{An}_{52-67}$ ). The texture systematically decreases in grain size and changes in Section $857 \mathrm{C}$ 59R-4 to sub-ophitic or diabase, although no chill or sediments were observed in this core. The top of Core 139-857C-60R (Unit 2) contains a chilled margin of fine-grained basalt with plagioclase phenocrysts whose texture coarsens conspicuously in the lower half of Section $857 \mathrm{C}-60 \mathrm{R}-1$ to a medium-grained diabase with strongly zoned plagioclase. The upper $20 \mathrm{~cm}$ of Section $857 \mathrm{C}-60 \mathrm{R}-2$ is a diabase with zoned plagioclase phenocrysts $\left(\mathrm{An}_{53-66}\right)$ that systematically decreases in grain size to a well-preserved basal contact with sediment. Diabase is again present at $857 \mathrm{C}-60 \mathrm{R}-2,49-142 \mathrm{~cm}$ (Unit 3), mostly as small unoriented pieces, including some coarse-grained samples. Phyric diabase with zoned plagioclase and pyroxene continues to Section 857C-61R$1,100 \mathrm{~cm}$ (Unit 4), where there is a sharp contact with sediment. The rock at the contact is fine-grained with plagioclase microlites and phenocrysts. The top of Section 857C-61R-2 is a fine-grained contact to a phyric diabase which makes up the remainder of Core 857C-61R (Unit 5). Core 857C-62R is composed of medium to coarse-grained diabase or ophite with pyroxene enclosing plagioclase $\left(\mathrm{An}_{51}\right)$ in a poikilitic texture and macroscopically conspicuous laths of ilmenite and granular magnetite. The coarsest grain size (e.g., 139-857C-62R$2,12-14 \mathrm{~cm}$ ) has large euhedral ilmenites extensively altered to leucoxene and strongly zoned plagioclase $\left(\mathrm{An}_{50-70}\right)$ and clinopyroxene (brown titaniferous rims). There is increased alteration at this horizon with clinopyroxene partially replaced by actinolite and islands of sodic plagioclase in large patches of chlorite. There are no contacts with sediment and no apparent reduction in grain size (Unit 6). The top of Core 857C-63R, however, is metamorphosed sediment with a diabase contact within a gravel horizon composed of mixed sediment and vesicular igneous fragments. The remainder of Core $857 \mathrm{C}-63 \mathrm{R}$ is a coarse-grained diabase with strongly zoned plagioclase $\left(\mathrm{An}_{32-70}\right)$ and zoned poikilitic pyroxene with ilmenite laths (Unit 7). Core 857C-64R is similarly coarse-grained diabase with subophitic texture and poikilitic clinopyroxene and skeletal ilmenite (Unit 8). A slight decrease in grain size occurs at the bottom of Section $857 \mathrm{C}-64 \mathrm{R}-2$, where fine- 

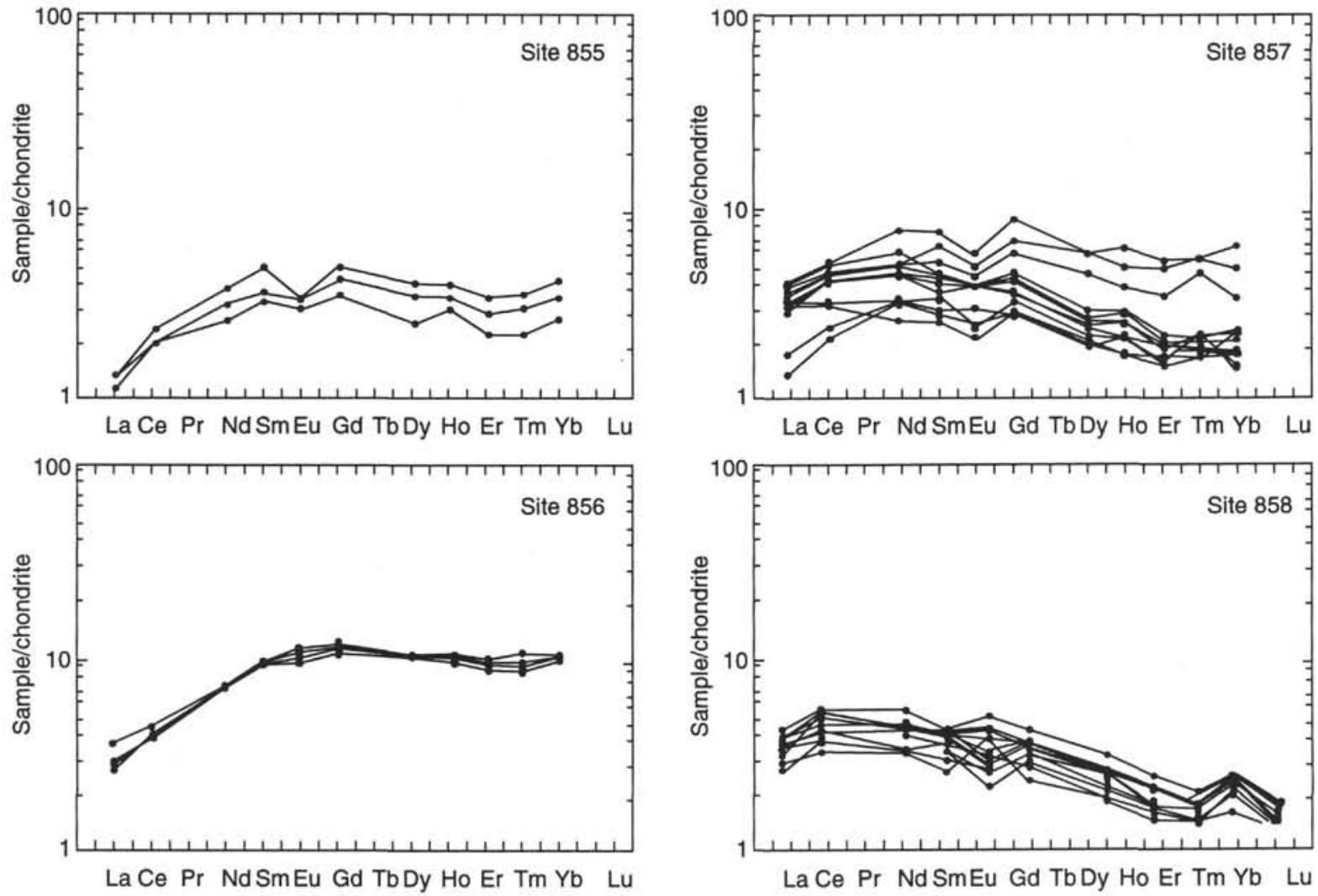

Figure 4. REE compositions for all sites, normalized to chondritic values.

grained diabase is cut by a wairakite-quartz-sphalerite vein that is $1-2$ $\mathrm{cm}$ thick. Fine-grained basalt is found as a few centimeter-sized fragments in gravel in the upper $5 \mathrm{~cm}$ of Section 857C-65R-1 (Unit 9), in contact with a sedimentary horizon. A baked sediment contact above a highly altered basaltic horizon was found at $24 \mathrm{~cm}$ depth in Section 857C-66R-1. This basaltic horizon (Unit 10) is unique in that it is a vertical contact between a basaltic intrusion and sediment, either a late crosscutting dike or the toe of a sill. This pale green altered basalt contains chlorite pseudomorphs after olivine or clinopyroxene (probably the latter, given the moderate plagioclase composition) and plagioclase phenocrysts (An60-69). A similar altered basalt fragment is present at the top of Core $857 \mathrm{C}-67 \mathrm{R}$ above a sedimentary horizon. Eighteen centimeters of fine- to medium-grained plagioclase-phyric diabase forms the bottom of Core $857 \mathrm{C}-67 \mathrm{R}$ below the sedimentary horizon (Unit 11). Core 857C-68R (Unit 12) is composed of coarsegrained poikilitic diabase unbroken by any chilled contacts.

\section{Hole $857 \mathrm{D}$}

In Hole $857 \mathrm{D}$, mafic sills and interlayered sediment were cored between 581.1 and 936.2 mbsf. Very coarse-grained horizons are fewer in number than recovered in Hole $857 \mathrm{C}$, and several units are composed of only a few pieces of rubble within a mostly sedimentary interval.

The top $110 \mathrm{~cm}$ of Core 139-857D-1R-1 (Unit 13) is a finegrained diabase that terminates with a chilled contact against sediment. Unit 14 is a fine-grained, plagioclase-phyric $\left(\mathrm{An}_{69-76}\right)$ diabase with a distinct upper contact with sediment at Section 139-857D-1R$2,65 \mathrm{~cm}$. This unit coarsens slightly in grain-size within Section 857D-2R-1. A few pieces of sedimentary rubble and a chilled contact at Core 857D-2R-1, $47 \mathrm{~cm}$, separate subunits 14A and 14B, which are lithologically identical. This fine- to medium-grained plagioclasephyric diabase extends to the bottom of Core 857D-3R. Unit 15 , in Core $857 \mathrm{D}-4 \mathrm{R}$, is a heavily veined, coarse-grained diabase that is bounded by sedimentary horizons, although no chilled contacts were recovered. The large grain size suggests that this interval is from the center of a large sill.

The lithology of the igneous intervals in Cores 857D-7R to 857D$9 \mathrm{R}$ is a fine- to medium-grain sparsely phyric diabase. This interval comprises subunits $16 \mathrm{~A}-\mathrm{C}$, which are separated by a chilled margin (Core 857D-8R-1, $0 \mathrm{~cm}$ ) and a small piece of sediment rubble (Core 857D-8R-1, 66-71 cm), respectively. A partially lithified sedimentary clast is included in the diabase at $857 \mathrm{D}-8 \mathrm{R}-1,34 \mathrm{~cm}$. Subunit $17 \mathrm{~A}$ has a distinctive chilled and massively altered margin at Section 857D$12 \mathrm{R}-1,21 \mathrm{~cm}$, which continuously grades into plagioclase-phyric fine-to medium-grain diabase. In this rock, plagioclase megacrysts $\left(\mathrm{An}_{83-94}\right)$ are associated with magnesiochromite. This same rock type is found in Subunit 17B, which is composed of a single piece of rubble within sedimentary horizons. Short intervals of fine-grained metadiabase and metabasalt within Sections 857D-15R-1 and 857D-16R-2 constitute subunits $18 \mathrm{~A}$ and $18 \mathrm{~B}$, respectively.

The top of Unit 19 (Section 857D-17R-3) is distinctive in the abundance of large sulfide-filled vesicles or vugs within a leucocratic, fine-grained diabase. Plagioclase displays oscillatory zonation $\left(\mathrm{An}_{55-63}\right)$ with similar zoning in $\mathrm{Mg}, \mathrm{Fe}$, and $\mathrm{Ti}$ in the clinopyroxene. This is the thickest unit in this hole, extending through Core 857D-20R, which contains melanocratic ophite with clinopyroxene poikilitically enclosing plagioclase $\left(\mathrm{An}_{45-70}\right)$ and equant grains of ilmenite. Igneous rock recovered from Sections 857D-21R-1 to 857D-24R-1 (Subunits 20AD) is leucocratic fine- to medium-grained diabase with local concentrations of plagioclase phenocrysts or embayed megacrysts $\left(A n_{77-82}\right)$. Short sedimentary intervals separate the subunits; otherwise, they appear to be lithologically identical.

Unit 21 extends from the bottom of Core 857D-24R to the bottom of Core 857D-26R. Except for a fine-grained contact, this unit is a medium-grained diabase with plagioclase glomerocrysts with thin sodic rims. An extensively metamorphosed fine-grained contact zone for Unit 22 is contained within Section 857D-27R-1. This unit is composed of veined and mineralized basaltic rubble and exhibits extensive 

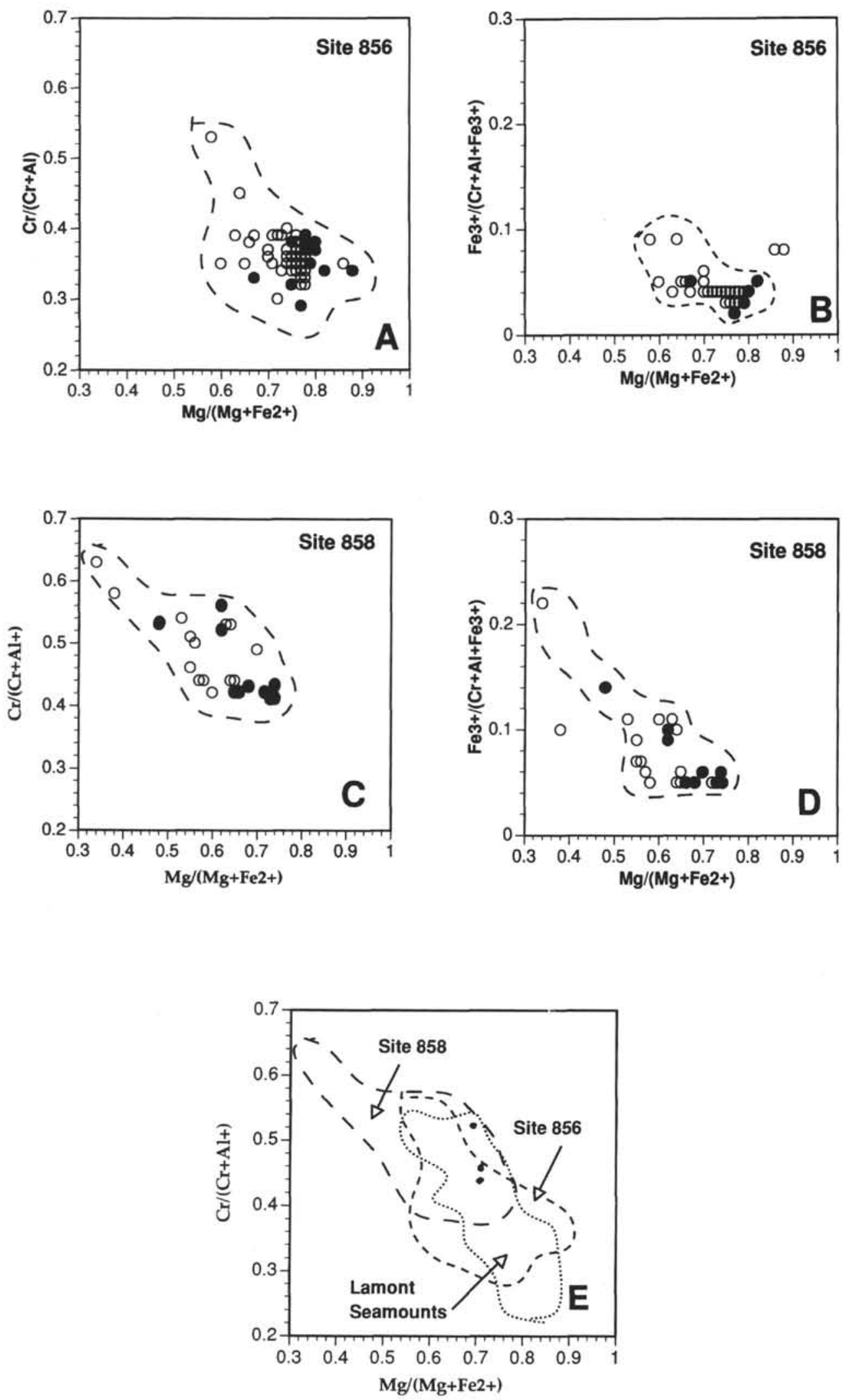

Figure 5. Spinel compositions for Leg 139 basalts. A. Cr\# vs. Mg\# for Site 856. Filled circles are core compositions. B. Fe\# vs. Mg\# for Site 856. Filled circles are core compositions. C. Cr\# vs. Mg\# for Site 858. D. Fe\# vs. Mg\# for Site 858. E. Comparison of different sites with Lamont Seamounts. Filled circles are Site 857. 
Table 6. Microprobe analyses of chromian spinel compositions, Leg 139, Sites 856-858.

\begin{tabular}{|c|c|c|c|c|c|c|c|c|c|c|c|c|c|c|c|c|c|c|c|c|c|c|c|c|}
\hline & $1^{a}$ & $2^{b}$ & $3^{c}$ & $4^{d}$ & $5^{e}$ & $6^{6}$ & $7^{8}$ & $8^{h}$ & $9^{i}$ & $10^{j}$ & $11^{k}$ & $12^{1}$ & $13^{\mathrm{m}}$ & $14^{\mathrm{n}}$ & $15^{\circ}$ & $16^{p}$ & $17^{4}$ & $18^{r}$ & $19^{s}$ & $20^{t}$ & $21^{u}$ & $22^{v}$ & $23^{\omega}$ & $24^{x}$ \\
\hline & 0.03 & 0.06 & 0.05 & 0.03 & 0.20 & 0.73 & 0.09 & 0.04 & 0.22 & 0.07 & 0.08 & 0.14 & 0.04 & 0.03 & 0.03 & 0.03 & 0.11 & 0.14 & 0.22 & 0.02 & 0.03 & 0.05 & 0.06 & 0.15 \\
\hline & 0.25 & 0.28 & 0.27 & 0.31 & 0.36 & 0.89 & 0.34 & 0.28 & 0.26 & 0.29 & 0.28 & 0.32 & 0.17 & 0.16 & 0.15 & 0.58 & 1.22 & 1.25 & 1.02 & 0.70 & 0.74 & 0.66 & 0.54 & 3.33 \\
\hline $\mathrm{Ab} \mathrm{C}$ & 38.01 & 37.96 & 37.16 & 33.55 & 35.42 & 22.22 & 36.47 & 39.19 & 37.49 & 39.16 & 38.04 & 37.92 & 26.30 & 29.66 & 31.21 & 23.20 & 21.17 & 20.22 & 26.15 & 30.70 & 29.56 & 27.97 & 29.06 & 13.39 \\
\hline & 28.80 & 29.02 & 29.87 & 33.26 & 27.96 & 38.05 & 29.86 & 27.64 & 29.88 & 27.97 & 28.90 & 29.86 & 42.13 & 38.00 & 35.43 & 37.75 & 38.93 & 38.26 & 30.63 & 34.38 & 34.63 & 35.13 & 34.19 & 34.35 \\
\hline & 3.98 & 3.57 & 3.55 & 3.51 & 4.92 & 7.79 & 3.77 & 3.53 & 3.62 & 3.52 & 3.13 & 4.03 & 3.12 & 3.20 & 3.94 & 7.30 & 8.55 & 8.71 & 8.56 & 4.90 & 4.76 & 5.97 & 5.61 & 16.47 \\
\hline & 18.13 & 18.00 & 17.68 & 16.98 & 13.62 & 12.17 & 16.55 & 17.89 & 18.34 & 18.53 & 17.56 & 19.03 & 15.61 & 15.93 & 15.83 & 13.13 & 13.37 & 13.13 & 11.52 & 15.32 & 12.91 & 12.05 & 12.61 & 6.49 \\
\hline & & 0.22 & 0.11 & 0.17 & 0.24 & 0.31 & 0.24 & 0.14 & 0.15 & 0.10 & 0.10 & 0.11 & 0.14 & 0.18 & 0.19 & 0.19 & 0.25 & 0.28 & 0.27 & 0.16 & 0.21 & 0.22 & 0.21 & 0.56 \\
\hline & 9.81 & 9.94 & 10.43 & 10.68 & 16.17 & 15.99 & 11.98 & 10.39 & 9.59 & 9.45 & 10.65 & 9.23 & 12.00 & 11.81 & 12.18 & 14.16 & 14.54 & 15.01 & 15.89 & 12.94 & 16.48 & 17.62 & 16.81 & 22.53 \\
\hline ota & 99.20 & 99.05 & 99.12 & 98.49 & 98.89 & 98.16 & 99.30 & 99.12 & 99.55 & 99.09 & 98.741 & 100.64 & 99.51 & 98.96 & 98.96 & 96.31 & 98.14 & 97.00 & 94.26 & 99.12 & 99.32 & 99.66 & 99.10 & 97.26 \\
\hline & 0.007 & 0.013 & 0.011 & 0.008 & 0.047 & 0.183 & 0.022 & 0.009 & 0.049 & 0.017 & 0.018 & 0.032 & 0.01 & 0.006 & 0.006 & 0.007 & 0.024 & 0.032 & 0.056 & 0.004 & 0.007 & 0.012 & 0.013 & 0.040 \\
\hline & & & & & & & 0.058 & & 044 & & & & & & & 0.1 & & & & 0.125 & & & & \\
\hline & & 10.1 & & & & 6.5 & & 10.4 & 50 & 10.3 & & & & & & & & & & & & & 93 & \\
\hline & & 5.1 & & & & 7.5 & & 4.9 & & & & & & & & & & & & & & & & \\
\hline & & & & & & 1.469 & 0.650 & & & & & & 0 & 0.5 & & & & & & & & & & \\
\hline & & 6.070 & 5.96 & 5.883 & 4.765 & 4.543 & 5.650 & 6.009 & 6.154 & 6.199 & & & 5.5 & 5.6 & & 4.9 & 4.9 & & & 5.396 & & 4.361 & & \\
\hline & 0.0 & 0.042 & 0.0 & 0.034 & 0.0 & 0.065 & 0.046 & 0.026 & 0.029 & 0.019 & 0.019 & 0.0 & 0.0 & 0.0 & & 0.0 & 0.0 & & 0.0 & 0.031 & & & 0.0 & 0.1 \\
\hline & & & & & & 3.348 & 2.294 & & & & & & & & & & & & & & & & & \\
\hline atsur & 23 & & & & & & 2.297 & & & & & & & & & & & & & & & & & \\
\hline & & 339 & 0.35 & 0.399 & 0.346 & 0.535 & 355 & 0.321 & 348 & 0.324 & 0.338 & 0.346 & 0.518 & 0.462 & 0.432 & & & 0.559 & 0.440 & 0.429 & 0.440 & 0.457 & 0.441 & 0.6 \\
\hline & & & & & & & & & & & & & & & & & & & & & & & & \\
\hline & 0.042 & 0.038 & 0.038 & 0.039 & 0.055 & 0.094 & 0.041 & 0.038 & 0.039 & 0.037 & 0.034 & 0.043 & 0.035 & 0.036 & 0.044 & 0.088 & 0.102 & 0.108 & 0.105 & 0.055 & 0.054 & 0.069 & 0.064 & 0.224 \\
\hline LIQ Mg/Fe & 2.11 & 2.06 & 1.97 & 2.00 & 1.00 & 1.28 & 1.62 & 1.91 & 2.21 & 2.18 & 1.86 & 2.38 & 1.95 & 1.85 & 1.72 & 1.52 & 1.67 & 1.56 & 0.94 & 1.62 & 1.09 & 0.99 & 1.05 & 0.71 \\
\hline Liquid Mg\# & 0.68 & 0.67 & 0.66 & 0.67 & 0.50 & 0.56 & 0.62 & 0.66 & 0.69 & 0.69 & 0.65 & 0.70 & 0.66 & 0.65 & 0.63 & 0.60 & 0.63 & 0.61 & 0.49 & 0.62 & 0.52 & 0.50 & 0.51 & 0.41 \\
\hline
\end{tabular}

a 139-856A-14X-1, 68-70 cm, core, large euhedral grain.

b $139-856 \mathrm{~A}-14 \mathrm{X}-1,68-70 \mathrm{~cm}$, rim, large euhedral grain.

c 139-856A-14X-1, 68-70 cm, large euhedral megacryst.

d 139-856A-14X-1, 68-70 cm, small groundmass grain.

e $139-856 \mathrm{~A}-14 \mathrm{X}-1,68-70 \mathrm{~cm}$, rim, large grain.

139-856 A-14X-1, 68-70 cm, rim, small groundmass grain.

g 139-856A-14X-1, 116-118, rim.

h 139-856A-14X-1, 116-118, core, previous grain

139-856B-8H-CC, 1-3 cm, core, large grain.

139-856B-8H-CC, $1-3 \mathrm{~cm}$, rim, large grain.

139-856B-9H-1, 4-8 cm, rim, medium grain

139-856B-10H-1, 64-67 cm, outer zone.

m 139-857D-12R-1, 51-53 cm, core, euhedral grain.

139-857D-12R-1, 51-53 cm, rim, euhedral grain.

139-857D-12R-1, $51-53 \mathrm{~cm}$, small euhedral grain.

p 139-858 $-29 \mathrm{R}-1,27-39 \mathrm{~cm}$, small grain in chlorite pseudomorph.

4 139-858G-3R-1, $24-25 \mathrm{~cm}$.

139-858G-3R-1, 24-25 cm, may be altered.

$139-858 \mathrm{G}-3 \mathrm{R}-1,24-25 \mathrm{~cm}$, may be altered.

139-858G-16R-1, $81-83 \mathrm{~cm}$, core, large euhedral grain.

139-858 G-16R-1, $81-83 \mathrm{~cm}$, middle, large euhedral grain.

139-858G-16R-1,81-83 cm, rim, large euhedral grain

139-858G-16R-1, 81-83 cm, rim, strongly zoned grain. 
Table 7. Microprobe analyses of oxide minerals, Leg 139.

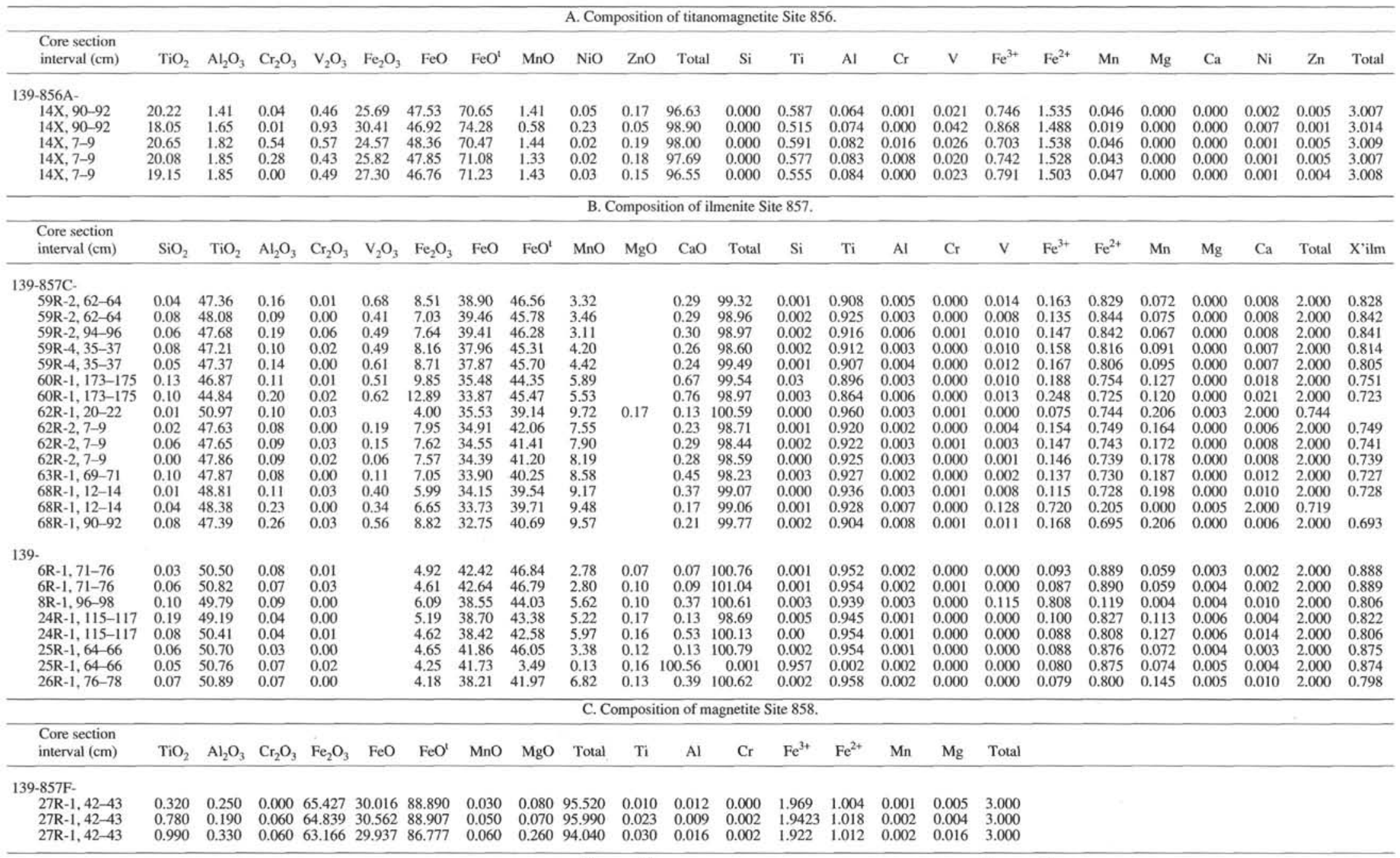

Notes: Structural formula calculated on the basis of four oxygens with calculated values of $\mathrm{Fe}^{3+}$ and $\mathrm{Fe}^{2+}$. $\mathrm{FeO}$ is total iron calculated as $\mathrm{FeO} \mathrm{Fe}_{2} \mathrm{O}_{3}, \mathrm{FeO} \mathrm{Fe}^{3+}$, and $\mathrm{Fe}^{2+}$ are calculated by stoichiometry. $\mathrm{X}$ ilm is mole fraction ilmenite in mineral. 
Table 8. Microprobe analyses of sulfide minerals, Leg 139, Site 856.

\begin{tabular}{|c|c|c|c|c|c|c|c|c|c|c|c|c|c|}
\hline \multicolumn{14}{|c|}{ A. Pyrrhotite and pentlandite compositions. } \\
\hline $\begin{array}{l}\text { Core, section, } \\
\text { interval }(\mathrm{cm})\end{array}$ & $\mathrm{Cu}$ & $\mathrm{Fe}$ & $\mathrm{Ni}$ & $\mathrm{S}$ & Total & Fe mole & Ni mole & $\mathrm{S}$ mole & $\mathrm{Cu}$ mole & $\begin{array}{c}\text { Fe mole } \\
\%\end{array}$ & $\begin{array}{c}\text { Ni mole } \\
\%\end{array}$ & $\begin{array}{c}S \text { mole } \\
\%\end{array}$ & Total \\
\hline \multicolumn{14}{|l|}{$139-856 \mathrm{~A}-$} \\
\hline $14 X-1,7-9$ & 0.01 & 31.31 & 36.17 & 32.75 & 100.26 & 0.561 & 0.616 & 1.020 & 0.000 & 0.255 & 0.280 & 0.464 & 1.000 \\
\hline $14 X-1,7-9$ & 0.00 & 60.16 & 0.83 & 39.75 & 100.76 & 1.078 & 0.014 & 1.238 & 0.000 & 0.463 & 0.006 & 0.531 & 1.000 \\
\hline $14 X-1,90-92$ & 0.06 & 33.44 & 33.11 & 33.16 & 99.77 & 0.599 & 0.564 & 1.033 & 0.001 & 0.273 & 0.257 & 0.470 & 1.000 \\
\hline $14 X-1,90-92$ & 3.64 & 54.10 & 4.84 & 36.86 & 99.46 & 0.970 & 0.082 & 1.148 & 0.057 & 0.429 & 0.037 & 0.509 & 0.975 \\
\hline $14 X-1,90-92$ & 0.00 & 57.49 & 3.07 & 38.53 & 99.10 & 1.030 & 0.052 & 1.200 & 0.000 & 0.451 & 0.023 & 0.526 & 1.000 \\
\hline $14 \mathrm{X}-1,90-92$ & 0.10 & 60.15 & 1.12 & 39.05 & 100.44 & 1.078 & 0.019 & 1.217 & 0.002 & 0.466 & 0.008 & 0.525 & 0.999 \\
\hline $14 X-1,90-92$ & 0.08 & 59.99 & 1.08 & 38.65 & 99.83 & 1.075 & 0.018 & 1.204 & 0.001 & 0.468 & 0.008 & 0.524 & 0.999 \\
\hline $14 \mathrm{X}-1,90-92$ & 0.00 & 60.85 & 0.51 & 37.64 & 99.01 & 1.091 & 0.009 & 1.173 & 0.000 & 0.480 & 0.004 & 0.516 & 1.000 \\
\hline \multicolumn{14}{|l|}{ 139-856B- } \\
\hline $1 \mathrm{H}-1,48-50$ & 0.97 & 60.13 & 0.00 & 38.75 & 100.55 & 1.078 & 0.000 & 1.207 & 0.015 & 0.467 & 0.000 & 0.523 & 0.990 \\
\hline $1 \mathrm{H}-1,48-50$ & 0.37 & 60.48 & 0.02 & 38.77 & 100.58 & 1.084 & 0.000 & 1.208 & 0.006 & 0.470 & 0.000 & 0.523 & 0.993 \\
\hline \multicolumn{14}{|c|}{ B. Copper minerals. } \\
\hline $\begin{array}{l}\text { Core, section, } \\
\text { interval }(\mathrm{cm})\end{array}$ & $\mathrm{Cu}$ & $\mathrm{Fe}$ & Mn & $\mathrm{Zn}$ & $\mathrm{Cd}$ & $S$ & Total & Cu mole & Fe mole & $S$ mole & $\begin{array}{c}\text { Fe mole } \\
\%\end{array}$ & $\begin{array}{c}\text { S mole } \\
\%\end{array}$ & \\
\hline \multicolumn{14}{|l|}{$139-856 \mathrm{~A}-$} \\
\hline $14 X-1,90-92$ & 33.79 & 31.00 & 0.00 & 0.17 & 0.00 & 34.62 & 99.58 & 0.532 & 0.556 & 1.079 & 0.256 & 0.497 & \\
\hline $14 X-1,90-92$ & 33.96 & 31.00 & 0.03 & 0.14 & 0.01 & 34.45 & 99.59 & 0.535 & 0.556 & 1.073 & 0.257 & 0.496 & \\
\hline $14 \mathrm{X}-1,90-92$ & 33.76 & 30.46 & 0.02 & 0.20 & 0.00 & 34.35 & 98.79 & 0.532 & 0.546 & 1.070 & 0.254 & 0.498 & \\
\hline
\end{tabular}

replacement of plagioclase $\left(\mathrm{An}_{53-69}\right)$ by chlorite. Some pieces are very coarse-grained and presumably come from highly altered centers of large (fractured?) sills. Section 857D-29R-1 (Subunit 23A) is a highly epidotized diabase that systematically increases in grain size from top to bottom. Strongly zoned plagioclase $\left(\mathrm{An}_{66-49}\right)$ is partially replaced by quartz and epidote. This unit is adjacent to intervals of epidote-rich sandstone. Cores 857D-30R to 857R-32R (Subunits 23B-G) are similar epidotized and chloritized fine-grained diabase, with intervening sediment and bleached metabasalt contact zones separating subunits. The pieces are small and discontinuous and may be a series of thin, highly fractured sills.

A conspicuous quenched margin for Unit 24 was observed in Core 857D-33R-1, with a bleached contact zone and inner vesicle-rich zone that grades rapidly into a medium-grained diabase. Subunit $25 \mathrm{~A}$ is a single piece of variolitic basalt in Core 139-34R-1. Subunits 25B (Core 139-35-1, $0 \mathrm{~cm}$ to 139-36-1, $22 \mathrm{~cm}$ ) and 25C (Core 139-36R-1, $32 \mathrm{~cm}$ to $139-36-1,143 \mathrm{~cm}$ ) are similarly fine-grained diabase; they increase in grain size and become more mafic toward their bases to ophitic textures with some poikilitic clinopyroxenes. In subunit 25B, plagioclase $\left(\mathrm{An}_{34-72}\right)$ is altered to quartz and albite. In subunit $25 \mathrm{C}$, plagioclase $\left(\mathrm{An}_{45-68}\right)$ shows normal, reversed and oscillatory zonation and replacement by epidote. Unit $26(139-37 \mathrm{R}-1,17-20 \mathrm{~cm})$ is a small single piece of epidotized diabase within a sedimentary interval.

\section{Petrography and Mineral Chemistry}

No fresh olivine was observed in any of the sills, although small euhedral pseudomorphs are interpreted to be replacements of either olivine or clinopyroxene. The mafic pseudomorphs are composed of smectite/chlorite or chlorite. In one unit they are associated with spinel, in which they likely are replacements of olivine.

Spinel was observed in only one thin section from Unit 17A. It has a $\mathrm{Cr} \#(=\mathrm{Cr} / \mathrm{Cr}+\mathrm{Al})=0.52-0.43$ and $\mathrm{a} \mathrm{Mg} \#(=\mathrm{Mg} / \mathrm{Mg}+\mathrm{Fe})=$ $0.70-0.71$ (Table 6 ). This spinel occurs as strongly zoned euhedral crystals in a sill containing unusually calcic plagioclase. The sill occurs at the stratigraphic horizon of the most intense alteration that may be associated with a fault.

The Fe-oxide phase in the Site 857 sills is dominated by ilmenite (Table 7) with sparse magnetite and no titanomagnetite, in contrast to the samples from Site 856. The ilmenite is observed as interstitial anhedral grains in the finer-grained portions of the sills and as spectacular euhedral or skeletal tabular plates in the coarser-grained portions of the sills. Ilmenite together with its alteration products, makes up
Table 9. Unit designations for igneous rocks from Site 857.

\begin{tabular}{cll}
\hline Unit & \multicolumn{1}{c}{ Top } & \multicolumn{1}{c}{ Bottom } \\
\hline & & \\
$139-857 \mathrm{C}-$ & & \\
1 & $59 \mathrm{R}-1,0 \mathrm{~cm}$ & $59 \mathrm{R}-4,139 \mathrm{~cm}$ \\
2 & $60 \mathrm{R}-1,0 \mathrm{~cm}$ & $60 \mathrm{R}-2,31 \mathrm{~cm}$ \\
3 & $60 \mathrm{R}-2,49 \mathrm{~cm}$ & $60 \mathrm{R}-2,142 \mathrm{~cm}$ \\
4 & $61 \mathrm{R}-1,0 \mathrm{~cm}$ & $61 \mathrm{R}-1,100 \mathrm{~cm}$ \\
5 & $6 \mathrm{R}-2,0 \mathrm{~cm}$ & $61-2,82 \mathrm{~cm}$ \\
6 & $62 \mathrm{R}-1,0 \mathrm{~cm}$ & $62 \mathrm{R}-2,79 \mathrm{~cm}$ \\
7 & $63 \mathrm{R}-1,34 \mathrm{~cm}$ & $63 \mathrm{R}-1,73 \mathrm{~cm}$ \\
8 & $64 \mathrm{R}-1,0 \mathrm{~cm}$ & $64 \mathrm{R}-2,133 \mathrm{~cm}$ \\
9 & $65 \mathrm{R}-1,0 \mathrm{~cm}$ & $65-1,5 \mathrm{~cm}$ \\
10 & $66 \mathrm{R}-1,24 \mathrm{~cm}$ & $67-1,5 \mathrm{~cm}$ \\
11 & $67 \mathrm{R}-1,58 \mathrm{~cm}$ & $67 \mathrm{R}-1,76 \mathrm{~cm}$ \\
12 & $68 \mathrm{R}-1,0 \mathrm{~cm}$ & $68 \mathrm{R}-3,36 \mathrm{~cm}$ \\
& & \\
$139-857 \mathrm{D}-$ & & \\
13 & $1 \mathrm{R}-1,0 \mathrm{~cm}$ & $1 \mathrm{R}-1,110 \mathrm{~cm}$ \\
$14 \mathrm{~A}$ & $1 \mathrm{R}-2,65 \mathrm{~cm}$ & $2 \mathrm{R}-1,38 \mathrm{~cm}$ \\
$14 \mathrm{~B}$ & $2 \mathrm{R}-1,47 \mathrm{~cm}$ & $3 \mathrm{R}-2,123 \mathrm{~cm}$ \\
15 & $4 \mathrm{R}-1,7 \mathrm{~cm}$ & $4 \mathrm{R}-2,89 \mathrm{~cm}$ \\
$16 \mathrm{~A}$ & $7 \mathrm{R}-1,0 \mathrm{~cm}$ & $7 \mathrm{R}-1,52 \mathrm{~cm}$ \\
$16 \mathrm{~B}$ & $8 \mathrm{R}-1,0 \mathrm{~cm}$ & $8 \mathrm{R}-1,66 \mathrm{~cm}$ \\
$16 \mathrm{C}$ & $8 \mathrm{R}-1,71 \mathrm{~cm}$ & $9 \mathrm{R}-1,122 \mathrm{~cm}$ \\
$17 \mathrm{~A}$ & $12 \mathrm{R}-1,21 \mathrm{~cm}$ & $12 \mathrm{R}-2,133 \mathrm{~cm}$ \\
$17 \mathrm{~B}$ & $13 \mathrm{R}-1,7 \mathrm{~cm}$ & $13 \mathrm{R}-1,12 \mathrm{~cm}$ \\
$139-857 \mathrm{D}-$ & & \\
$18 \mathrm{~A}$ & $15 \mathrm{R}-1,35 \mathrm{~cm}$ & $15 \mathrm{R}-1,63 \mathrm{~cm}$ \\
$18 \mathrm{~B}$ & $16 \mathrm{R}-2,55 \mathrm{~cm}$ & $16 \mathrm{R}-2,65 \mathrm{~cm}$ \\
19 & $17 \mathrm{R}-3,48 \mathrm{~cm}$ & $20 \mathrm{R}-1,119 \mathrm{~cm}$ \\
$20 \mathrm{~A}$ & $21 \mathrm{R}-1,18 \mathrm{~cm}$ & $21 \mathrm{R}-1,115 \mathrm{~cm}$ \\
$20 \mathrm{~B}$ & $21 \mathrm{R}-1,135 \mathrm{~cm}$ & $21 \mathrm{R}-1,140 \mathrm{~cm}$ \\
$20 \mathrm{C}$ & $22 \mathrm{R}-1,0 \mathrm{~cm}$ & $22 \mathrm{R}-1,14 \mathrm{~cm}$ \\
$20 \mathrm{D}$ & $22 \mathrm{R}-1,31 \mathrm{~cm}$ & $24 \mathrm{R}-1,12 \mathrm{~cm}$ \\
21 & $24 \mathrm{R}-1,104 \mathrm{~cm}$ & $26 \mathrm{R}-1,96 \mathrm{~cm}$ \\
22 & $27 \mathrm{R}-1,17 \mathrm{~cm}$ & $28 \mathrm{R}-1,7 \mathrm{~cm}$ \\
$23 \mathrm{~A}$ & $29 \mathrm{R}-1,32 \mathrm{~cm}$ & $29 \mathrm{R}-2,44 \mathrm{~cm}$ \\
$23 \mathrm{~B}$ & $30 \mathrm{R}-1,16 \mathrm{~cm}$ & $30 \mathrm{R}-1,19 \mathrm{~cm}$ \\
$23 \mathrm{C}$ & $30 \mathrm{R}-1,25 \mathrm{~cm}$ & $30 \mathrm{R}-1,36 \mathrm{~cm}$ \\
$23 \mathrm{D}$ & $30 \mathrm{R}-1,39 \mathrm{~cm}$ & $31 \mathrm{R}-1,4 \mathrm{~cm}$ \\
$23 \mathrm{E}$ & $31 \mathrm{R}-1,53 \mathrm{~cm}$ & $31 \mathrm{R}-1,91 \mathrm{~cm}$ \\
$23 \mathrm{~F}$ & $31 \mathrm{R}-1,91 \mathrm{~cm}$ & $31 \mathrm{R}-1,108 \mathrm{~cm}$ \\
$23 \mathrm{G}$ & $32 \mathrm{R}-1,0 \mathrm{~cm}$ & $32 \mathrm{R}-1,65 \mathrm{~cm}$ \\
24 & $33 \mathrm{R}-1,18 \mathrm{~cm}$ & $33 \mathrm{R}-1,98 \mathrm{~cm}$ \\
$25 \mathrm{~A}$ & $34 \mathrm{R}-1,88 \mathrm{~cm}$ & $34 \mathrm{R}-1,95 \mathrm{~cm}$ \\
$25 \mathrm{~B}$ & $35 \mathrm{R}-1,0 \mathrm{~cm}$ & $36 \mathrm{R}-1,22 \mathrm{~cm}$ \\
$25 \mathrm{C}$ & $36 \mathrm{R}-1,32 \mathrm{~cm}$ & $36 \mathrm{R}-1,143 \mathrm{~cm}$ \\
26 & $37 \mathrm{R}-1,17 \mathrm{~cm}$ & $37 \mathrm{R}-1,20 \mathrm{~cm}$ \\
\hline & & \\
& & \\
\hline & &
\end{tabular}


about $3 \%$ of the rock. The average ilmenite composition is $\mathrm{Fe}_{0.90} \mathrm{Ti}_{0.93}$ $\mathrm{Mn}_{0.12} \mathrm{O}_{3}$. The manganese contents of these ilmenite grains is unusually high (average $6.1 \mathrm{wt} \%$ ) if compared with typical ilmenite compositions (Haggerty, 1976). The ilmenite in sills from 470 to $510 \mathrm{mbsf}$ have progressively increasing Mn contents. Magnetite was observed as anhedral grains that were frequently altered or completely replaced, presumably by sulfide. No microprobe analyses were obtained.

Plagioclase is present as zoned phenocrysts or microphenocrysts intergrown with clinopyroxene (Table 4). In Hole 857D, large plagioclase megacrysts are also present with compositions varying from $\mathrm{An}_{80-89}$ (Table 4). Zoned phenocrysts have core compositions varying from $\mathrm{An}_{60-73}$. Plagioclase contained in poikilitic intergrowths with pyroxene tend to show less chemical zonation and presumably preserve primary compositions. The rims of the phenocrysts and the compositions of the microphenocrysts are more sodic, averaging $\mathrm{An}_{50-60}$. Sodic compositions observed as rims on phenocrysts or patches in altered microphenocrysts may not be primary, but are typically $\mathrm{An}_{40-50}$. Although many of the plagioclase crystals show conspicuous optical zonation and replacement by secondary minerals, including chlorite and epidote, albitic rims on plagioclase $(\mathrm{An}<20)$ are relatively rare. Albitic compositions were only analyzed in two samples from the bottom of Hole $857 \mathrm{D}$ from Units $25 \mathrm{~B}$ and 25C. Small patches of albitic plagioclase were rarely observed as anhedral relicts within masses of chloritic replacements (?) $140-142 \mathrm{~cm}$, (pc. 6) with $\mathrm{An}_{12-15}$ ). Extreme plagioclase values $\left(\mathrm{An}_{95-83}\right)$ have also been observed for megacrysts in Unit 17A. It is notable that these are associated with magnesiochromite, suggesting an unusually primitive magmatic composition for this unit or that the megacrysts are not related to the host magma.

Clinopyroxene is present as large phenocrysts intergrown with included plagioclase in an ophitic texture, as small barrel-shaped microphenocrysts, and as granular to spherulitic groundmass phases (Table 5). The clinopyroxene is highly variable in composition with both normal and reversed zonation in $\mathrm{Al}, \mathrm{Cr}$, and $\mathrm{Ti}$ contents common (Table 5). Cores of poikilitic clinopyroxenes are typically aluminous with $\mathrm{Al}_{2} \mathrm{O}_{3}>4 \%$. Many of these also have high $\mathrm{Cr}$ contents with $\mathrm{Cr}_{2} \mathrm{O}_{3}$ $>1 \%$. Rims of zoned pyroxene crystals are normal augite with $\mathrm{Al}_{2} \mathrm{O}_{3}$ of $2 \%-3 \%$ and $\mathrm{Cr}<0.8 \%$. Brownish rims of pyroxene also contain high $\mathrm{Ti}(>1 \%)$. These rims are frequently observed on pyroxenes intergrown with plagioclase either poikilitically enclosing plagioclase or as symplectites. Less commonly, rims on pyroxenes are subcalcic augites with $\mathrm{Al}_{2} \mathrm{O}_{3}<2 \%$ and $\mathrm{CaO}<19 \%$ (e.g., Sample 139-857C-60R-2, 17-19 cm, [piece 1]). These subcalcic augites are high in $\mathrm{FeO}$ and low in $\mathrm{Cr}_{2} \mathrm{O}_{3}$ and $\mathrm{TiO}_{2}$, suggesting a highly evolved magmatic composition with ilmenite on the liquidus. In contrast, groundmass clinopyroxene commonly contains high $\mathrm{Al}_{2} \mathrm{O}_{3}$ (up to $6 \%$ ) and $\mathrm{TiO}_{2}$ (over 3\%) (e.g., Sample 139-857C-66R-1, 108-110 cm [piece 16]). This latter sample is from a highly altered crosscutting dike that forms Unit 10. These variations in clinopyroxene chemistry are interpreted to represent both variable primary magma composition and the effect of extremely variable cooling rates for the magmas once intruded into the sediment.

The principal sulfide minerals are pyrite, pyrrhotite, chalcopyrite, isocubanite, and sphalerite, all of which are interpreted to be secondary in origin. These occur as aggregates disseminated throughout the bulk of the rock and as vein fillings that precipitated from hydrothermal fluids. Pyrrhotite occurs more predominantly in the lower sills in Site 857. The nickel content of pyrrhotite, although variable, is high, typically ranging from $0.18 \%$ to $2.01 \%$. Two analyses from Sample 139-857D-26R-1, 76-78 cm, contain $10.2 \%$ and $12.4 \% \mathrm{Ni}$, representing exceptional amounts of nickel for pyrrhotite. Nickel is bimodally distributed in pyrrhotite; low molar percent (mol\%) Fe pyrrhotite (less than $46 \mathrm{~mol} \% \mathrm{Fe}$ ) contains a uniform amount of nickel (1.4 mol\%), whereas high Fe-pyrrhotite ( $>46 \mathrm{~mol} \% \mathrm{Fe}$ ) contains only about $0.5 \mathrm{~mol} \% \mathrm{Ni}$. Although the distribution and textures of the pyrrhotite grains in Site 857 sills generally indicate that they have been deposited after the rock was completely crystallized, their high nickel content may indicate that they have a magmatic parent.

\section{Alteration of the Site 857 Sill Complex}

The sills recovered from Site 857 are variably metamorphosed and interlayered with altered or indurated sediment. Fine-grained quenched sill margins exhibit intense hydrothermal recrystallization and are extensively metasomatised. Such margins are bleached to a pale gray and are completely replaced by pale magnesian chlorite $(\mathrm{Mg} / \mathrm{Fe}>2)$ with quartz and titanite. These are anomalously high in $\mathrm{Mg}, \mathrm{Al}$, and $\mathrm{Ti}$ compared to less-altered samples. Included microlites and phenocrysts are replaced, predominantly by green chlorite and epidote joined by actinolite in the lower half of Hole 857D. The most abundant and largest vein networks crosscut these highly altered margins and extend into the fresher rock slightly beyond the extent of the chill. Typical vein fillings include green ferroan chlorite/smectite, sulfide minerals, quartz, zeolites (most notably wairakite with $\mathrm{Ca} / \mathrm{Ca}+\mathrm{Na}$ $=95)$ and epidote $\left(\mathrm{Ps}_{8-30}\right.$, including thulite with $\left.\mathrm{Mn}>1 \%\right)$. The chilled margins of the sills and the immediately adjacent interval typically are vesicle-rich. The vesicles are almost all filled, most frequently with green ferroan chlorite, but also with quartz, epidote, prehnite, smectite, or sulfide minerals.

The second most intensely metamorphosed intervals are the coarsegrained sill interiors. The quantity of chloritic replacement of mesostasis and crystals is variable, with some intervals exhibiting over $50 \%$ replacement. The igneous plagioclase is strongly zoned and includes replacement by a variety of minerals including sodic plagioclase, epidote, chlorite, and prehnite. White sodic rims and mottled extinction in the plagioclase phenocrysts suggest that these are partially replaced by sodic plagioclase, yet abundant albite was not detected by microprobe. Much of the strong zonation in the plagioclase could in fact be primary. Pervasive alteration is best developed in Hole $857 \mathrm{D}$ where chlorite, epidote, and titanite are consistently present in greater abundances than observed in Hole 857C, and are the dominant vein minerals. The least-altered rocks are fine-to-medium grained diabase not associated with chilled margins. The alteration in the freshest intervals is limited to replacement of the sparse amounts of mesostasis.

Prehnite occurs in Unit 14B, both filling veins and replacing plagioclase. A substantial mass flux of $\mathrm{Ca}$ is suggested by the abundance of calcic vein minerals. Similarly the mass flux of magnesium is evidenced by the abundance of chlorite and the spuriously high $\mathrm{Mg}$ numbers (Table 1; Fig. 2) based on the whole-rock chemistry.

The whole-rock chemistry for all of the sills reflects the impact of this pervasive alteration, with total volatile content $\left(\mathrm{H}_{2} \mathrm{O}+\mathrm{S}\right.$, or $\left.\mathrm{LOI}\right)$ ranging from 1.3 to $8.4 \mathrm{wt} \%$. Oxygen isotopic analyses of whole-rock powders vary from $\delta^{18} \mathrm{O}=2.5-4.5 \%$, suggesting alteration at temperatures above $250^{\circ} \mathrm{C}$ (Table 2). These extremely depleted values for $\delta^{18} \mathrm{O}$ probably reflect the abundance of chlorite and formation of secondary sodic plagioclase (Stakes, unpubl. data). The most highly altered samples are in the uppermost section of sill, between 450 and $650 \mathrm{mbsf}$. This area is coincident with a high deformation zone (fractures and faulted rocks), and is also distinguished by a much higher content of veins.

\section{Geochemistry}

Alteration has undoubtedly modified the $\mathrm{MgO}$ and $\mathrm{CaO}$ contents and possibly other constituents in many if not all of these samples. $\mathrm{MgO}$ content does correlate with $\mathrm{H}_{2} \mathrm{O}$ in the overall data set, and correlates poorly with $\mathrm{Ni}(\mathrm{r}=0.5)$. These are the expected relationships if $\mathrm{Mg}$ was added from seawater during alteration, as no corresponding nickel would be added. In addition, the calculated $\mathrm{Mg}$ numbers are extremely high and are inconsistent with the mineralogy as well as the calculated magma Mg\# from the spinel in Unit 17. This suggests the addition of seawater $\mathrm{MgO}$. In an attempt to determine some aspects of the primary igneous nature of these rocks, a subset of "least altered samples" was established. These 21 samples have less than $3.0 \%$ total volatile content; included in these are samples with 

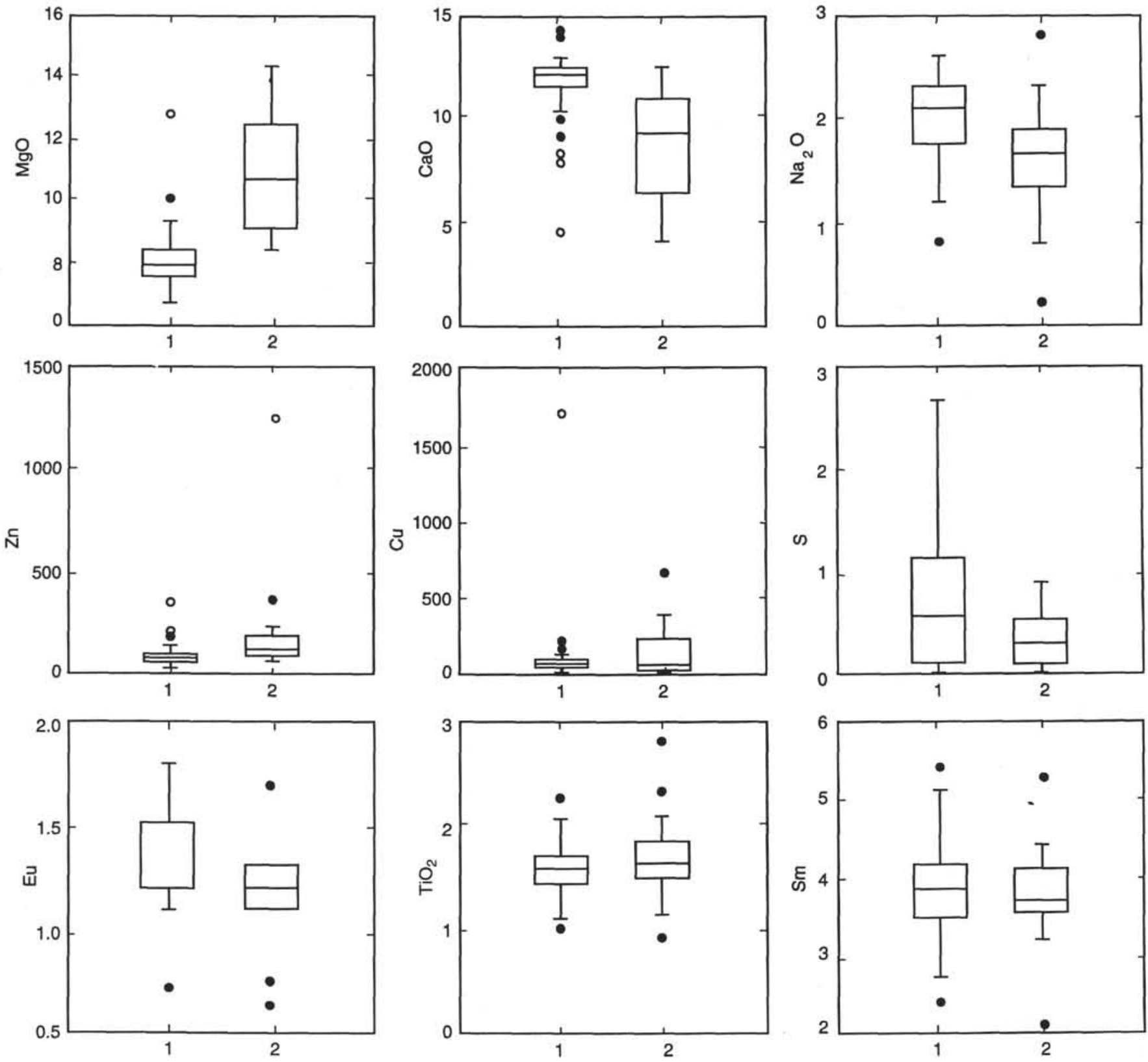

Figure 6. Box plots comparing selected major and trace elements compositions of "unaltered" (Group 1) and "altered" (Group 2) samples, chosen as described in text.

less than $0.9 \%$ total sulfur. A comparison of "unaltered" (Group 1) and "altered" (Group 2) data sets is provided in Figure 6. The unaltered subset is significantly lower in $\mathrm{MgO}$ and significantly higher in $\mathrm{CaO}$ than the altered samples. In eliminating samples with volatile contents higher than $3 \%$, it is possible that a few samples with higher primary ferromagnesian contents may have been excluded. For example, the spinel-bearing sill was not included in the unaltered subset although it is likely one of the most primitive units sampled at this site. In the filtered data set, $\mathrm{Ni}$ correlates moderately well with $\mathrm{MgO}$ $(\mathrm{r}=0.8)$, an expected primary igneous relationship. Thus the filtered data set is a fair representation of primary igneous compositions, diluted by addition of $\mathrm{H}_{2} \mathrm{O}$, but likely not affected in a major way by $\mathrm{Mg}$ addition. This filtering puts an upper limit on total $\mathrm{MgO}$ content of about $9.5 \mathrm{wt} \%$. Thus it is likely that any samples containing more than this content of $\mathrm{MgO}$ are highly altered and of little use in determining primary igneous petrochemical trends.

Examination of the sulfur distribution in the "unaltered" suite of samples indicates a bimodal sulfur distribution. One population con- tains samples with a maximum of $1800 \mathrm{ppm}$ sulfur, the other from $1800-9000 \mathrm{ppm}$. The latter group of samples have had much sulfur added and thus have been somewhat altered. In considering whether to eliminate these high sulfur samples from the "unaltered" population, we examined the compositional changes between a sample suite (nine samples) containing low $(<0.13 \%) \mathrm{S}$, a larger suite (the "unaltered" suite determined above) containing $<3.0 \%$ total volatile content ( 21 samples), and the total suite of samples. The average copper content of the overall sample population is about $45 \%$ higher (125 ppm) than the "unaltered" and low-S suite (90 and 85 ppm, respectively), but virtually identical in the latter two suites. Zinc shows a gradual increase, from $74 \mathrm{ppm}$ for the low-S suite, to 91 for the "unaltered" suite, to $102 \mathrm{ppm}$ for the total suite. The "immobile" elements $\left(\mathrm{TiO}_{2}, \mathrm{Cr}, \mathrm{Ni}, \mathrm{Y}, \mathrm{Yb}, \mathrm{Zr}\right.$, and the REEs) do not differ significantly between the total suite of samples and the "unaltered" suite of 21 samples. Thus for petrochemical considerations using these elements, we use the full suite of analyses; when using the major elements, the "unaltered" suite is used. 


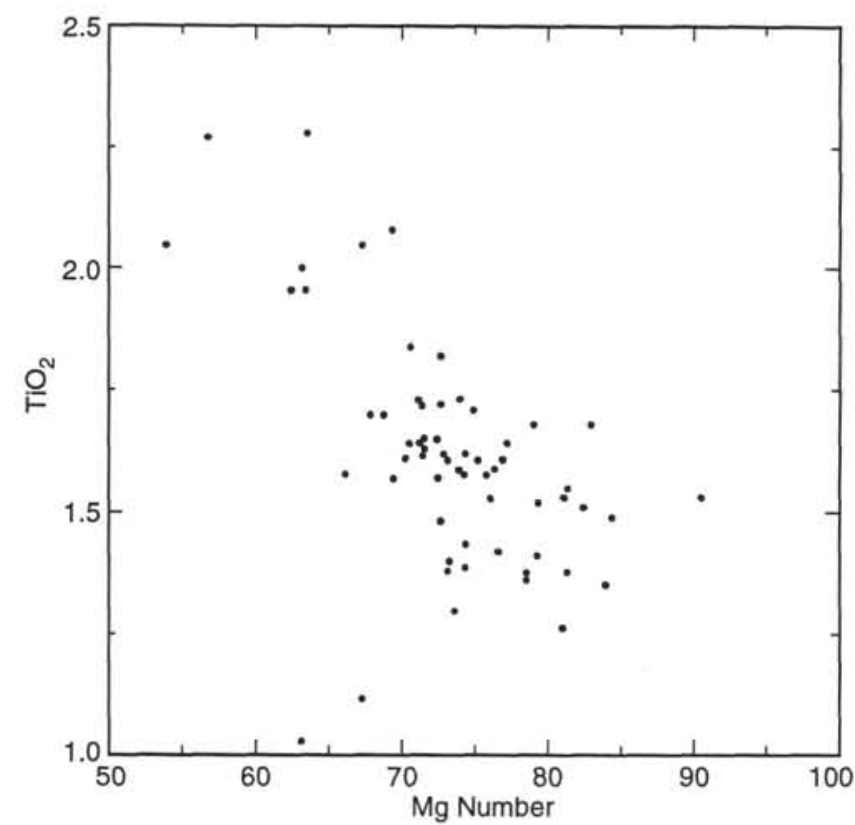

Figure 7. $\mathrm{TiO}_{2} \mathrm{Mg}$ number for samples from Site 857 with total volatiles $<3 \%$ ("unaltered suite"), including shipboard data. Note variation in $\mathrm{TiO}_{2}$ at single value of $\mathrm{Mg}$ number.

\section{Major Element Data}

For the complete set of data (Fig. 2), the range of $\mathrm{Na}_{2} \mathrm{O}$ values is less than that of Site 858 and Site 855 , suggesting little uptake of $\mathrm{Na}_{2} \mathrm{O}$ due to alteration. Relative to average MORB, the rocks are substantially depleted in $\mathrm{K}$ due to alteration. In the sediments, $\mathrm{K}, \mathrm{Rb}$, and $\mathrm{Ba}$ are completely removed by hydrothermal alteration (see Goodfellow and Peter, this volume).

The plot of $\mathrm{TiO}_{2}$ vs. Mg number, using both shipboard and new data filtered to remove the most-altered samples (Fig. 7) illustrates that these samples form a grossly linear trend due to crystal fractionation. However, samples show considerable variation in $\mathrm{TiO}_{2}$ at the same $\mathrm{Mg} \#$, suggesting separate magma fractionation series from different parental magmas. This suggests that the sill complex may be composed of magmas resulting from variable degrees of partial melting and may not be contemporaneous. Similarly, on a plot of $\mathrm{Na}_{2} \mathrm{O}$ vs. $\mathrm{MgO}$ (Fig. 8), the filtered data form two subparallel trends similar to the liquid lines of descent calculated by Klein and Langmuir (1987). Both lines indicate low-pressure fractionation, possibly from two parent magmas. A high-and-low $\mathrm{Fe}$ trend is similarly seen in $\mathrm{Fe}_{2} \mathrm{O}_{3}$ vs. Mg\# plot (Fig. 2). Many of the sills are high in both Fe and $\mathrm{Ti}$, similar to samples from propagating rifts (Christie and Sinton, 1986). However, considerable variations exist in $\mathrm{Fe}$ and $\mathrm{Ti}$ at the same $\mathrm{Mg \#}$. These variations must represent separate fractionation paths.

\section{Trace Element Data}

A plot of $\mathrm{TiO}_{2}$ vs. $\mathrm{Zr}$ (Fig. 3) shows a roughly linear trend similar to the $\mathrm{TiO}_{2}$ vs $\mathrm{Mg}$ \# plot due to the strong control by fractionational crystallization. For any value of $\mathrm{TiO}_{2}$, however, there is a range of values of $\mathrm{Zr}$ that cannot be related to differentiation. These variations must reflect multiple parental magmas resulting from a heterogeneous mantle source or, more likely, variable extent of partial melting of a single source region. The high $\mathrm{Zr}$ trend coincides with that of Site 858 and the low $\mathrm{Zr}$ trend coincides with that of Site 855. The values for $\mathrm{Zr} / \mathrm{Nb}$ (15-57; Davis, Mottl, Fisher, et al., 1992) and $\mathrm{Zr} / \mathrm{Y}$ $(2.53-4.67)$ suggest that the sills include mostly normal (N-MORB) units with transitional compositions (T-MORB) in Units 10-12. Sills in Unit $8(\mathrm{Zr} / \mathrm{Nb}=29-30)$ and Unit $13(\mathrm{Zr} / \mathrm{Nb}=27)$ are also more enriched than the basalts from Sites 855 and 856 .

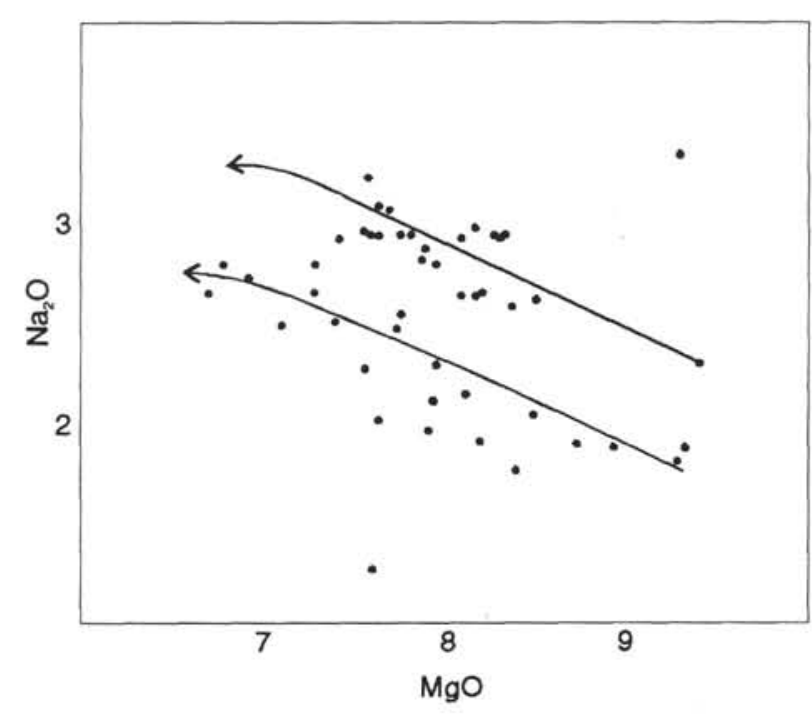

Figure $8 . \mathrm{MgO}$ vs. $\mathrm{Na}_{2} \mathrm{O}$ for "unaltered" suite of samples from Site 857 sills. Two fractionation trends are defined, suggesting two parent magmas for these sills.

The REE contents range from 10 to about 25 times chondrite, and form two groups (Fig. 4). Both are depleted in La relative to Ce with [ $\mathrm{La} / \mathrm{Ce}]_{\mathrm{n}}$ ratios of 0.73 to 0.99 . One group has a flat middle and heavy REE pattern ( $[\mathrm{Ce} / \mathrm{Yb}]_{n}<1 ;$ Fig. 3$)$, but the other has a slight depletion in the heavy REEs $\left([\mathrm{Ce} / \mathrm{Yb}]_{n}>1\right.$; Fig. 3 ). The only exception is found in the highly altered crosscutting dike in which Unit 10 shows a slight enrichment in $\mathrm{La}$ compared to $\mathrm{Ce}\left([\mathrm{La} / \mathrm{Ce}]_{\mathrm{n}}=1.01\right)$, possibly resulting from the extensive alteration or a different magma type. Eu depletion is notable in some samples, absent in others, and enriched slightly in a few plagioclase-rich samples, suggesting variable fractionation and accumulation of plagioclase within the sills. Samples with a negative Eu anomaly tend to show a more pronounced depletion in the LREE.

The data were examined stratigraphically in order to see if the sills form coherent groups or display any systematic variations with depth. On a plot of chondrite-normalized $[\mathrm{La} / \mathrm{Yb}]_{\mathrm{n}}$ vs. depth (Fig. 9), several variations are evident. The data generally cluster into two groups, Group I, with $[\mathrm{La} / \mathrm{Yb}]_{\mathrm{n}}$ greater than 1 , and Group II, with $[\mathrm{La} / \mathrm{Yb}]_{\mathrm{n}}$ less than 1 . On the plot of this ratio vs. depth below seafloor, the two groups apparently alternate with depth. Within the lower Group II clusters, the data for closely spaced sills trend to lower $[\mathrm{La} / \mathrm{Yb}]_{\mathrm{n}}$ with depth. No relationship between total REE content and depth is obvious at the scale of individual sills or clusters of sills, although the total REE contents appear to increase with depth below 600 mbsf. The position of each sill in Holes $857 \mathrm{C}$ and $857 \mathrm{D}$ was calculated using the logs for total gamma-ray counts and resistivity (Davis, Mottl, Fisher, et al., 1992). The sill contacts are identifiable within a few tens of centimeters, as the mafic rock is significantly less radioactive and more resistive than the adjacent sediment. These sills are plotted on a section showing the REE profiles (Fig. 10); the latter are positioned to reflect their approximate stratigraphic position. On this plot, several aspects are evident. Sills from the upper $50 \mathrm{~m}$ of Hole $857 \mathrm{C}$ (Core 139-857C-59R-1 to Core 139-857C-62R-2, Unit 1 to Unit 6; 450-500 mbsf) have generally flat patterns with LREE depletion in the lower members. Slight positive and negative europium anomalies occur within this horizon. Sills from the lower portion of Hole 857C (Core 139-857C-68R-1 to Core 857C-68R-3; Unit 7 to Unit 12; 500 to 570 mbsf) have flat REE patterns, with downward progressively larger negative europium anomalies with increasing depth. The only exception is the crosscutting dike (Unit 10), which is slightly enriched in LREE. Four sills from the top of Hole 857D (Core 857D-3R-1 to Core 857D-12R-1; Unit 14 to Unit 17,570 to $700 \mathrm{mbsf}$ ) are LREE depleted, and have pronounced negative Eu anomalies. They are similar 


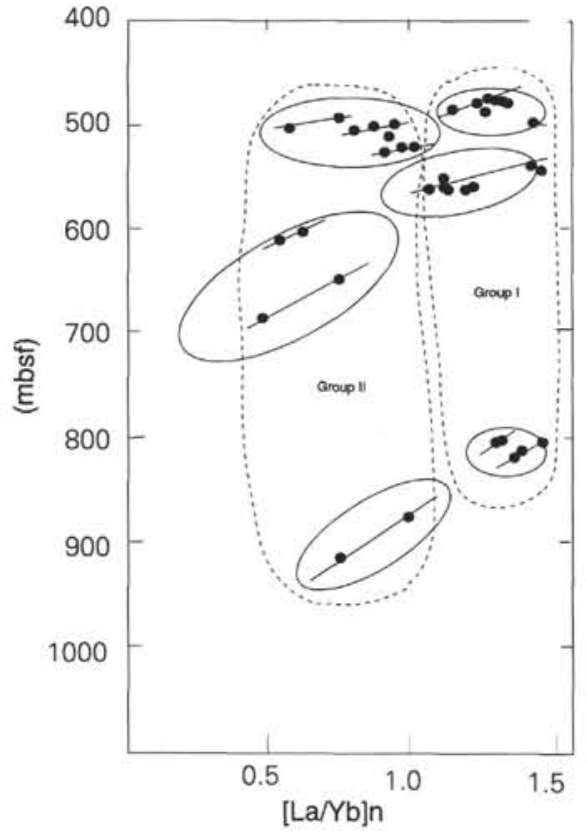

Figure 9. $[\mathrm{La} / \mathrm{Yb}]_{\mathrm{n}}$ ratio vs. depth of samples from sills at Site 857 (chondrite normalized).

in total REE concentrations and REE patterns to the samples from Site 855. Sills below 700 mbsf (Core 857D-24R-1 to Core 857D-36R-1, Unit 21 to Unit 26) have flat patterns, with the sills below $850 \mathrm{mbsf}$ (Cores 857D-32R-1 and 857D-36R-1, Unit 23 to Unit 26) displaying slight LREE depletion. The development of the negative Eu anomaly in the sills from 500 to $750 \mathrm{mbsf}$ is indicative of removal of plagioclase from the melt. As the sills are quite thin (typically $10 \mathrm{~m}$ ) and seemingly homogeneous (determined by petrographic examination, plus multiple samples from several of the sills, such as Unit 12, and others as shown in Fig. 10), this separation probably occurred in a shallow crustal magma chamber. The sill containing unusually calcic plagioclase and magnesiochromite (Unit 17) shows the largest negative Eu anomaly and the strongest depletion in the LREE. It is also one of the most altered, suggesting that the large Eu depletion may be due in part to plagioclase alteration. The values for $\delta^{18} \mathrm{O}$ for this horizon $(2.4-4.5 \%)$ reflect the intense alteration of plagioclase and replacement by chlorite. The variable sample compositions suggest that the sills originated from at least two separate magmatic episodes or two small disconnected magma chambers.

\section{Site 858, Holes F and G}

\section{Setting}

The igneous units intersected at the bottom of Hole $858 \mathrm{~F}$ were at a horizon considered too shallow for basement. However, the finegrained nature of the rocks, the well-developed and ubiquitous variolitic textures, numerous chilled contacts, and the chemical uniformity of the basalt flows suggested to shipboard petrologists that this might be anomalously shallow basement - either a constructional high or an uplifted block adjacent to a buried basement fault. Drilling at Hole $858 \mathrm{G}$ was undertaken to determine the nature of the igneous unit and to penetrate as deeply as possible into igneous basement at an active hydrothermal area. Rare cherty pebbles were the only "sedimentary" material recovered within these holes below the basalt-sediment interface, supporting the interpretation that the drilling was into a topographic high comprised of extrusives.

All the igneous rocks recovered from Site 858 are basalt flows with variable quantities of tabular to columnar plagioclase, euhedral chro-

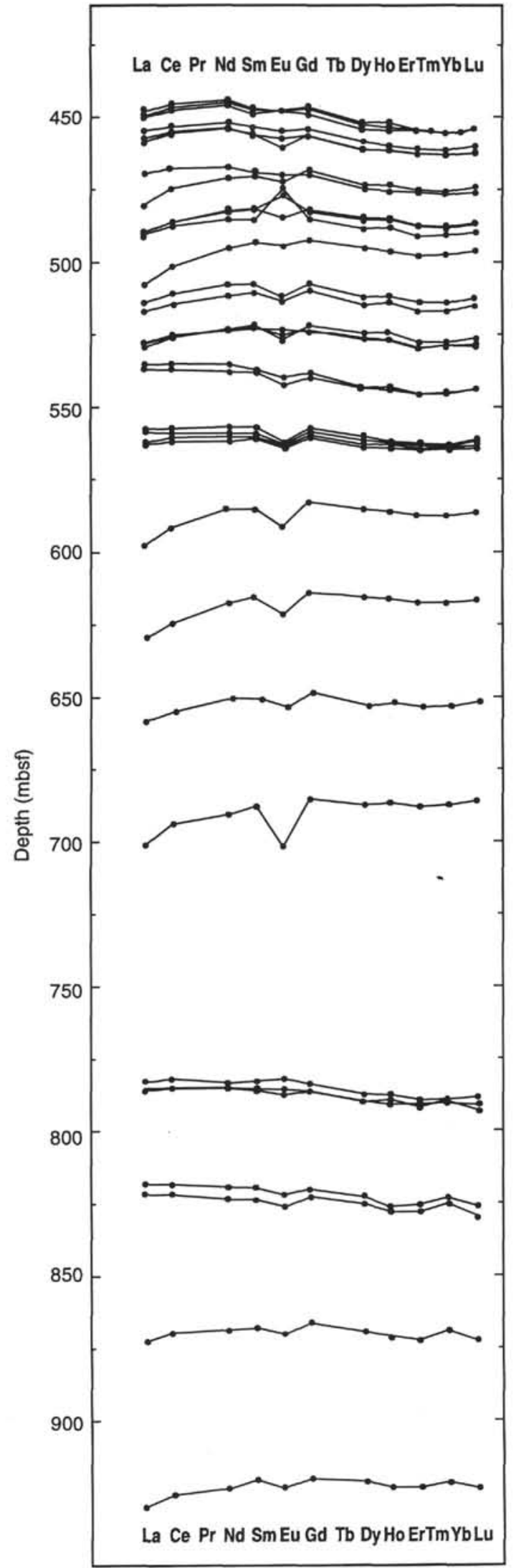

Figure 10. REE patterns plotted with depth in Holes 857C and 857D. Exact thickness of sill was determined from radiometric and resistivity logs, and is accurate to about $50 \mathrm{~cm}$. Unit numbers are described in text. 
mian spinel, and mafic silicates pseudomorphed by chlorite-smectite. Plagioclase is also present as a quenched phase with skeletal (lantern shapes and swallowtails on larger crystals) morphology. Much of the plagioclase is replaced by epidote and albitic plagioclase throughout both holes. The groundmass for most of the samples varies from cryptocrystalline or variolitic to microcrystalline, although no fresh glass is preserved. The only coarse-grained horizon is the basal unit for Hole 858G, which is a diabase (Sample 139-858G-16-1, 38-90 cm).

\section{Petrography and Mineral Chemistry}

The mafic phenocrysts are usually ovoid and replaced by a mixture of green to yellow pleochroic chlorite and smectite. The shapes of the pseudomorphs most clearly suggest olivine rather than pyroxene.

Spinel phenocrysts are dark red and commonly zoned with rims higher in $\mathrm{Cr}$ than the cores (Table 6; Fig. 5). The outer Cr-rich rim is conspicuous and frequently has inclusions of ilmenite and glass. The spinel phenocrysts are not uniformly present in the two Site 858 holes. They are common phenocrysts in the upper $40 \mathrm{~m}$ of basalt (from 249.9 to $288 \mathrm{mbsf}$ ) and in the lowermost basalt recovered from Hole $858 \mathrm{G}$ ( 413 to $423.7 \mathrm{mbsf}$ ). Small, sparse spinel crystals are also rarely noted at $296 \mathrm{mbsf}$ and between $345 \mathrm{mbsf}$ and $413 \mathrm{mbsf}$. Mg numbers vary from 0.35 to 0.75 and $\mathrm{Cr}$ numbers vary from 0.40 to 0.54 with one sample as high as 0.62 (Figs. 5C and 5D).

A few grains of ilmenite and magnetite were identified (Table 7, section B). These are small, anhedral, isolated blebs within the mesostasis. Magnetite is uniform in composition, with $\mathrm{TiO}_{2}$ and $\mathrm{Al}_{2} \mathrm{O}_{3}$ contents typical of igneous rocks. Using the QUILF program (Anderson et al., 1993), an equilibrium temperature of about $800^{\circ} \mathrm{C}$ is indicated for the coexisting magnetite-ilmenite pair. This indicates that subsolidus equilibration of the oxide minerals was terminated at a fairly high temperature, although below expected eruption temperatures likely due to variable cooling of the basalt.

Plagioclase phenocrysts and microphenocrysts show strong optical and chemical zonation (Table 4). The most calcic phenocryst core compositions are $\mathrm{An}_{70-75}$, except for Sample 139-858G-16R-1, 47-49 $\mathrm{cm}$, which contains slightly more calcic plagioclase phenocrysts with core compositions of $\mathrm{An}_{76-80}$. Microphenocrysts and groundmass plagioclase have more sodic compositions, similar in composition to sodic rims on the phenocrysts, $\mathrm{An}_{58-69}$. Rarely, groundmass plagioclase is as sodic as $\mathrm{An}_{45}$. Plagioclase commonly contains patchy replacement by albitic plagioclase, which is easily distinguished by the anomalous extinction and break in chemistry to $\mathrm{An}_{3-20}$. Less commonly, plagioclase is partially replaced by epidote $\left(\mathrm{Ps}_{13-18}\right)$ analcime or prehnite, or even more rarely, by quartz and chlorite. The plagioclase compositions more calcic than about $\mathrm{An}_{45}$ are assumed to be primary.

Clinopyroxene is most commonly a granular to spherulitic groundmass mineral in the more crystalline samples in which $\mathrm{Al}_{2} \mathrm{O}_{3}$ contents vary from $>4 \%$ to $<2 \%$ (e.g., Sample 139-858-16R-1, 81-83 cm [piece 10]; Table 5). Where pyroxene is present as a phenocryst or microphenocryst phase it is typically higher in Ti than the associated groundmass phase.

Primary magmatic sulfides, such as those observed in samples from Site 856, are not present. Hydrothermal sulfides occur throughout most of the basalt samples from Holes $858 \mathrm{~F}$ and $858 \mathrm{G}$ as small $(0.1 \mathrm{~mm})$, evenly dispersed grains of pyrite, pyrrhotite, chalcopyrite, and sphalerite, or as vein fillings.

\section{Alteration}

The basalts from this hole have been variably altered with a high preservation of the original texture. Alteration minerals were principally identified in pseudomorphs, veins, and vesicle fillings. The initial descriptions suggest that the rocks are less pervasively altered than those at Site 857, and that much of the secondary mineralization is related to vein and vesicle fillings rather than bulk replacement. The uppermost units contain low-temperature phases (e.g., calcite, smectite, and celadonite) that are overprinted by higher temperature phases (e.g., epidote, chlorite/smectite, and talc) in the deeper portions of the hole. The whole-rock values for $\delta^{18} \mathrm{O}$ vary from $4.5 \%$ at the contact with the sediment to intervals only slightly depleted compared to fresh basalt $(5.5 \%$ ) (Table 2). The sediment adjacent to the contact is similarly depleted in $\delta^{18} \mathrm{O}\left(\delta^{18} \mathrm{O}=6.1 \%\right)$ compared to the shallower sediment $\left(\delta^{18} \mathrm{O}=7.1 \%\right)$. The fine-grained basalt at the contact with sediment (Sample 139-858F-25R-1, 107-108 cm) is pervasively replaced by pale magnesian chlorite mixed with quartz. Plagioclase phenocrysts in this rock are replaced by epidote and albite, phases which also fill veins and vesicles. Prehnite also locally fills veins.

Sulfides are ubiquitous in the igneous rocks from Site 858 in quantities of $1 \%-5 \%$ (much less than at Site 857). They are present in veins with epidote, quartz, chlorite, prehnite, and wairakite. They also form ovoid porphyroblasts within the body of the rock by indiscriminately replacing igneous phases. Most sulfides observed are pyrite, with lesser quantities of chalcopyrite found with ferroan chlorite on fracture surfaces.

\section{Geochemistry}

The samples from Site 858 are remarkably uniform in composition (Table 1) and likely represent a single geochemical unit, although there are multiple cooling units. At least one chilled margin was recovered in each core (Davis, Mottl, Fisher, et al., 1992). Thus the whole-rock compositions are unlikely to be strongly modified by crystal accumulation. These are all altered somewhat, with $\mathrm{H}_{2} \mathrm{O}$ contents of from 1.4 to $2.8 \mathrm{wt} \%$, and total sulfur contents from 0.01 to 2.7 $w t \%$. The $\mathrm{H}_{2} \mathrm{O}$ content is not well correlated with any other element. Only the samples with the highest water content have elevated $\mathrm{MgO}$ contents. Ten samples form a "background" population with a median S content of about $0.1 \%$, while the remainder form an "anomalous" population with a median content of about $0.9 \%$.

\section{Major Element Data}

In selecting a suite of unaltered samples, we excluded all samples with total $\mathrm{H}_{2} \mathrm{O}$ contents of more than 2.5 wt $\%$, and total sulfur contents more than $0.7 \mathrm{wt} \%$. This selection process eliminates samples that may have had significant additions or losses from or to either hydrothermal fluid or seawater. Eleven samples remain in this unaltered group.

The composition of the "unaltered" samples from this site are quite homogeneous. Their silica contents $(46.90 \%-49.90 \%)$ are slightly less than those for samples from the other sites ( 855 and 857). $\mathrm{TiO}_{2}(1.50 \%-1.61 \%)$ and $\mathrm{Al}_{2} \mathrm{O}_{3}(15.10 \%-16.40 \%)$ contents are similar to those for samples from Site 857. They are higher in $\mathrm{Na}_{2} \mathrm{O}$ than the other sites, but have the same range of $\mathrm{K}_{2} \mathrm{O}$. The Site 858 basalts lie at lower values of $\mathrm{Fe}_{2} \mathrm{O}_{3} \mathrm{~T}$ at the same $\mathrm{Mg} \#$ compared to the other sites (Fig. 2).

The magnesium numbers of samples from Site 858 vary between 62 and 64, similar to samples from Site 857, but higher than at Site 855 and lower than at Site $856 . \mathrm{Mg}$ number based on spinel core composition (see Discussion) vary from 60-63, consistent with the whole-rock values.

\section{Trace Element Data}

The $\mathrm{Ti}$ vs. $\mathrm{Zr}$ trend parallels that of Site 857 , but lies at higher values of $\mathrm{Zr}$ at the same $\mathrm{Ti}$. The $\mathrm{Zr} / \mathrm{Nb}$ values for basalts from Hole $858 \mathrm{~F}$ are consistent (30-32) and classify these as N-MORBs similar to some of the sills with transitional character from Site 857.

The REE data illustrate the homogeneity of these rocks. The patterns are all similar, showing a slight depletion in $\mathrm{La}\left([\mathrm{La} / \mathrm{Ce}]_{n}=\right.$ $0.84-0.94)$ and consistent depletion in the heavy REEs ([Ce/Yb $]_{n}$ $>1.3$ ) and a variably developed negative europium anomaly. In contrast, the $[\mathrm{La} / \mathrm{Sm}]_{n}$ is $\geq 1$, suggesting transitional or enriched affinities. The high values for $[\mathrm{Ce} / \mathrm{Yb}]_{n}$ and $[\mathrm{La} / \mathrm{Sm}]_{n}$ compared to the other sites could result from a lower percentage of partial melting of the source. The negative Eu anomaly suggests that only about half of the 
sampled flows show significant modification by fractionation of plagioclase. The single flow with a positive Eu anomaly suggests the accumulation of plagioclase phenocrysts, which is supported by petrography. The REE data are plotted in stratigraphic position in Fig. 11. The negative europium anomaly is not well developed in the uppermost and lowermost samples. The patterns are similar to those for basalts from the upper portion of Hole 857C (Cores 139-857C59R-1 to -60R-1; Units 1 and 2).

\section{DISCUSSION}

\section{Comparison of Phenocryst Data from the Four Sites}

Although there is no fresh glass preserved in most of these samples, many of the mineral phases preserve their primary composition and can be used to infer magmatic history. The compositions of olivine and spinel in particular provide information regarding the composition of the primary magma at each drill site in spite of extensive hydrothermal alteration. During alteration, olivine is completely replaced and spinel alters to optically conspicuous ferritchromite, leaving no ambiguity regarding the primary character of the optically fresh phases. Pyroxene similarly preserves its primary composition unless conspicuously replaced by hydrous phases such as smectite or chlorite. Pyroxene compositions, however, are complicated by the presence of multiple generations, including megacrysts, phenocrysts, microphenocrysts, and quenched groundmass phases. In addition, the extended crystallization history of the sills at Site 857 has resulted in strongly zoned pyroxenes. Plagioclase similarly includes multiple populations. Primary variation in plagioclase composition is further complicated by alteration, which typically produces an increase in the sodium content of the primary mineral rather than a discrete, optically conspicuous replacement phase.

\section{Spinel Compositions}

Variations in chromian spinel compositions are extremely valuable in deducing the composition of primary magmas. The composition of the spinel can be directly related to the $\mathrm{Mg} \#$ of the magma with which it equilibrated (Allan, in press). Spinel composition can be changed, however, under intense metamorphic conditions in which $\mathrm{Mg}$ may be preferentially removed to be incorporated into adjacent mixed layer clays (Allan, 1992). This would result in a large variation in $\mathrm{Mg \#}$ with no covariation in $\mathrm{Cr} \#(=\mathrm{Cr} /(\mathrm{Cr}+\mathrm{Al})$. The most $\mathrm{Mg}$-rich specimens, spinels found as inclusions in fresh olivine or plagioclase and the core compositions of the spinels, can be credibly related to primary magma compositions. In general, spinel is more resistant to hydrous alteration than olivine, however, and provides the best estimate of the magmatic $\mathrm{Mg} \#$ for sample suites in which no fresh glass is preserved.

Table 6 provides the calculated $\mathrm{Mg} \#$ of the original magma host for each of the spinel compositions based on the algorithms of Allan (in press). The magma Mg numbers for the Site 856 spinel core compositions are extremely primitive, from $0.65-0.70$. Groundmass spinel and rims on the larger grains are lower, varying from 0.50 to 0.62 . The core $\mathrm{Mg}$ numbers are equivalent to or slightly higher than those of glass composition reported by Karsten et al. (1990) for magmas off the axis of the Endeavour Segment. The Mg numbers are similar to slightly higher than the primitive compositions reported by Leybourne and Van Wagoner (1991) for East Peak of the Heck Seamount Chain, although these latter magmas contain only sparse spinel. The spinel compositions are most similar to spinels compositions in samples from West Ridge as described by Van Wagoner and Leybourne (1991). The West Ridge magmas have been interpreted to have formed within Middle Valley when it was still the locus of spreading for this area but fresh primitive magmas from here have been interpreted as products of a more recent off-axis melting event (Van Wagoner and Leybourne, 1991).

The core composition for the single sample with spinel from Hole $857 \mathrm{D}$ overlaps the Site 856 composition $(\mathrm{Mg} \#=0.66)$ with lower values for the rim and groundmass spinel $(\mathrm{Mg} \#=0.65$ and 0.63 ,

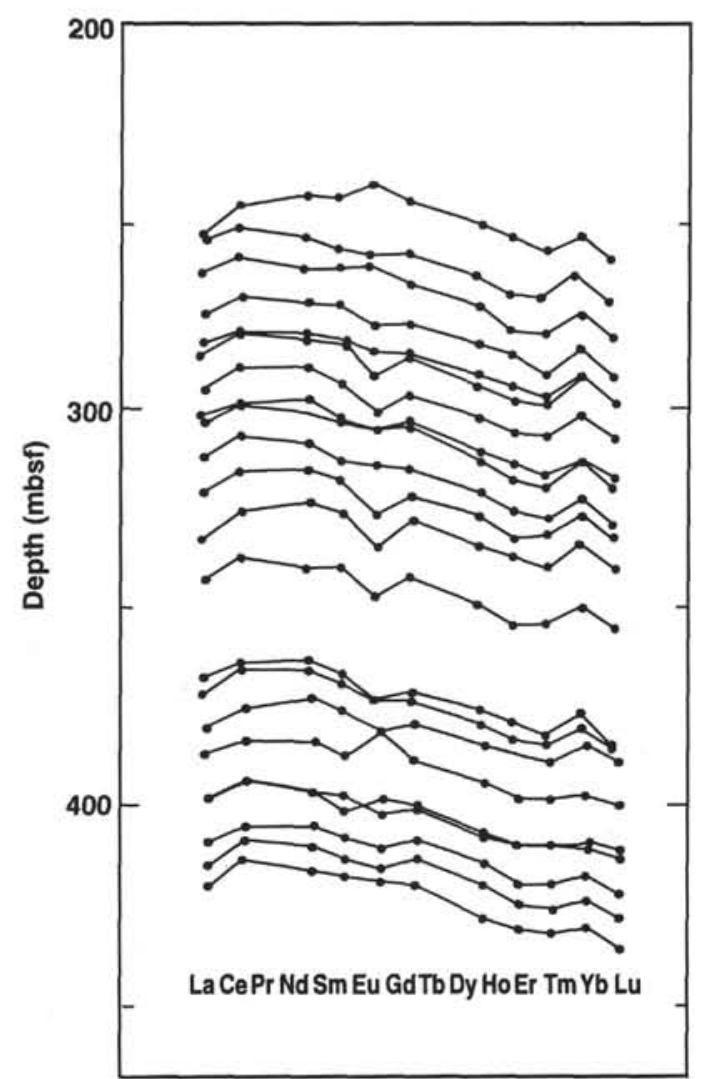

Figure 11. Chondrite-normalized REE patterns vs. depth below seafloor for basalts from Site 858 .

respectively), suggesting a similarly primitive composition. Unlike Site 856, however, the sample from Site 857D contains calcic plagioclase megacrysts $\left(\mathrm{An}_{95-83}\right)$ and less aluminous spinel, indicating contemporaneous plagioclase and spinel formation, as also occurred at Site 858. Magmatic Mg numbers calculated from the Site 858 spinel core compositions range from 0.63 to 0.51 , lower than those based on the spinel cores from Sites 856 and 857 . Spinel rims suggest evolved magma compositions $(0.49-0.52)$ with one Fe-rich spinel that indicates a magma $\mathrm{Mg \#}$ of 0.41 . Some of the spinels with calculated low $\mathrm{Mg}$ numbers from Site 858 also have low totals, which may suggest some effect of alteration.

Variations in the $\mathrm{Cr} \#$ of the spinels are correlated both with primary magma composition and low pressure crystal fractionation. Primitive magmas with high $\mathrm{Cr}$ contents will contain spinels with both high $\mathrm{Mg} \#$ and high $\mathrm{Cr} \#$ inherited from the mantle source region. Spinels that crystallize from more evolved magmas would contain lower $\mathrm{Cr}$ contents and lower $\mathrm{Cr} \#$ with lower $\mathrm{Mg \#}$. When plagioclase is present as a liquidus phase, however, the $\mathrm{Al}$ is preferentially included in this phase rather than the spinel. The result is a Cr-enriched rim with a low $\mathrm{Mg \#}$ produced by plagioclase fractionation at low pressures (Allan et al., 1988). Figure 5E is a plot of $\mathrm{Cr} \#$ vs. $\mathrm{Mg} \#$ for spinels from Sites 856,857 , and 858 . For a given lava suite derived from similar parental magmas, spinel $\mathrm{Cr} \#$ increases and $\mathrm{Mg} \#$ decreases with the amount of $\mathrm{Fe}$-enrichment, $\mathrm{Al}$ depletion, and extent of fractionation (Allan et al., 1988). The core compositions for Site 856 are offset to a slightly higher $\mathrm{Mg} \#$ than the spinels from Site 858 , suggesting a more primitive magma. However, for spinel core compositions with the same $\mathrm{Mg}$, the Site 858 magmas are consistently higher in $\mathrm{Cr}$. This suggests that these two magmas cannot be related by crystal fractionation. The single spinel found in one of the Site 857 sills plots in the center of the 858 population, though on the fringes of the 856 population, suggesting some affinity with the Site 858 magmas. 
Zoning and complex skeletal rims are not found in either population of spinels, suggesting a simple magmatic history for both Site 856 and Site 858, without substantial magma mixing. The presence of the sharply defined $\mathrm{Cr}$-rich (Al-poor) rim on a few crystals from Site 856 suggests some crustal fractionation of plagioclase. More extensive plagioclase fractionation for Site 857 and Site 858 is indicated by the lower aluminum content of the spinels compared to Site 856. Extensive fractionation is also indicated for the Fe-rich spinel in Site 858.

\section{Oxides}

The Fe-oxide compositions vary significantly between three areas (samples from Site 855 are too sparse to include). Site 856 contains groundmass titanomagnetite in addition to the rims on phenocrystic spinel. In contrast, Site 857 contains abundant ilmenite, indicative of the extensive crystal fractionation observed for some of the sills, but little modal magnetite or titanomagnetite. These latter phases may have been altered by the hydrothermal solutions, replaced by hydrous phases or by sulfide. The substantial addition of sulfur to the bulk rock compositions suggests that this latter process may be important. Variable Mn contents of the ilmenite may indicate differing extent of magma fractionation. Site 858 samples contain both ilmenite and magnetite, although neither is abundant. The moderate $\mathrm{TiO}_{2}$ and $\mathrm{Al}_{2} \mathrm{O}_{3}$ contents of the magnetite distinguishes it from the hydrothermal magnetite in the sulfide deposit at Site 856, which is barren of these constituents. Ilmenite-magnetite pairs indicate relatively high $\left(800^{\circ} \mathrm{C}\right)$ temperatures for the subsolidus equilibrium of these phases.

\section{Olivine Compositions}

Olivine is preserved in Site 855 and Site 856 samples. It is completely replaced in Site 858 samples and was likely present only in a few Site 857 samples. Olivine compositions for Site $856\left(\mathrm{Fo}_{88-90}\right)$ are considerably more magnesian than those at Site $855\left(\mathrm{Fo}_{83}\right)$. This is consistent with the primitive nature of the spinels present in the Site 856 basalts. Spinel is absent in the Site 855 basalts, perhaps as a result of a more extensive re-equilibration under crustal conditions. Neither group of olivine crystal contains significant zonation.

\section{Plagioclase Compositions}

The plagioclase in the Site 856 sills is more sodic than the plagioclase in the pristine Site 855 glassy basalts although the Site 856 olivines are more magnesian than those at Site 855. For Site 855, plagioclase phenocrysts are zoned from $\mathrm{An}_{90-85}$, whereas groundmass or microphenocrystic plagioclase is $\mathrm{An}_{78-70}$. At Site 856, in contrast, the plagioclase compositions vary from $\mathrm{An}_{78-64}$, including the large phenocrysts or megacrysts with conspicuous oscillatory zoning. This could be due to magma mixing or the inclusion of crystals in a mush into a younger primitive magma, since more calcic compositions would be consistent with the appearance of spinel and olivine. Plagioclase phenocrysts in basalts from Site 858 are similarly sodic in composition, with the largest phenocrysts having core compositions of $\mathrm{An}_{70-75}$, with only one sample as calcic as $\mathrm{An}_{80}$. As the alteration of plagioclase in the Site 858 samples is dominated by replacement by albite or epidote, these sodic compositions are considered primary. The more sodic plagioclase in basalts at Site 856 and 858 compared to Site 855 could point to a later appearance of plagioclase in these magmas, more extensive fractionation, or to a deeper source region that produces more sodic magmas that those at Site 855. The lack of a significant Eu anomaly for either the Site 856 or Site 858 magmas argues against extensive low-pressure crystal fractionation. The plagioclase in the sills from Site 857 shows extreme variation from $\mathrm{An}_{73-43}$ in a single sample. Another single sample contains highly calcic plagioclase phenocrysts $\left(\mathrm{An}_{95}\right)$ zoned to a more moderate composition $\left(\mathrm{An}_{83}\right)$. Because of the strong within-sample zonation, it is not possible to correlate average plagioclase composition with other geochemical parameters except in the sample with extremely calcic compositions.
The sodic plagioclase compositions in these sills could be a result of extensive fractional crystallization within the coarser portions of the sills or the result of hydrothermal alteration. The abundance of chlorite suggests that some of the sodic plagioclase could be secondary, at least the conspicuous white sodic rims on the larger crystals. This is supported by depleted oxygen isotope analyses. It is likely that in-situ differentiation and alteration both play a role in determining the plagioclase composition.

\section{Clinopyroxene}

Clinopyroxene compositions show a broad range among the four suites of rocks. Megacrystic clinopyroxene is characterized by higher $\mathrm{Al}$ and $\mathrm{Cr}$ contents and lower $\mathrm{Ti}$ and $\mathrm{Fe}$ contents. The large rounded megacrysts at Site 855 are good examples of this (Table 5). Pyroxenes of such compositions are also found within the Site 857 sills as cores for the large crystals that enclose plagioclase. Rim compositions of these poikilitic crystals are normal augite to subcalcic augite, once again reflecting the extreme crystal fractionation of the coarse sill interiors. High Ti pyroxene is also found as brownish rims on pyroxene phenocrysts. All compositions of pyroxenes were found in some sections, suggesting mixing of magmas from different sources. Anhedral groundmass clinopyroxene also tends to have high Al contents, but low $\mathrm{Cr}$ and variable $\mathrm{Ti}$. The aluminous groundmass pyroxene composition is assumed to reflect a quench effect. Site 856 only contains pyroxene as a groundmass phase. Most of the pyroxene at Site 858 is a groundmass phase, although some phenocrystic clinopyroxene was observed. The holocrystalline units at the base of Hole $858 \mathrm{G}$ contained pyroxene with both high and low $\mathrm{Al}$. The paucity of pyroxene in the basalts from Site 856 and 858 point to the relative unfractionated nature of these magmas when they were intruded or extruded, although they represent different initial magma compositions.

\section{Sulfide}

Only the sills recovered from Site 856 contain sulfides that appear to be magmatic in origin. These are polysulfide aggregates of $\mathrm{Ni}$-rich pyrrhotite with inclusions of pentlandite and chalcopyrite associated with plagioclase phenocrysts. The preservation of these delicate magmatic sulfide inclusions suggests that the Site 856 sills were little affected by hydrothermal circulation and must, as a result, postdate the event that produced the massive sulfide deposit at this site. The extraordinarily abundant sulfides in Site 857 are all hydrothermal in origin and represent a significant enrichment of $\mathrm{S}$ in the crust.

\section{Relationship of Different Magma Types from Different Sites}

Site 855 is composed of olivine-bearing, slightly altered tholeiite, typical of basalt elsewhere on the northern Juan de Fuca ridge and most similar to basalts described for south of the Cobb offset (Karsten et al., 1990). The refractory phenocrysts appear to be megacrysts not in equilibrium with the fresh glass host. These include forsteritic olivine, aluminous $\mathrm{Cr}$-rich clinopyroxene and calcic plagioclase. The refractory phenocrysts are similar in composition to megacrysts in basalts from slow and intermediate spreading ridges such as the MidAtlantic Ridge (Stakes et al., 1984), and Costa Rica Rift (Natland, 1980; Natland et al., 1983) and reflect compositional variations associated with a fractional crystallization of plagioclase, 3-6 km depth (e.g., negative europium anomaly in most fractionated samples). The refractory compositions of the megacrysts and their corroded or rounded morphology suggests resorption of these phases during ascent or possibly mixing of relatively primitive and evolved magmas. Site 855 basalts form a linear trend on a $\mathrm{Zr}$ vs. $\mathrm{TiO}_{2}$ plot and are LREE-depleted $\left.[\mathrm{La} / \mathrm{Sm}]_{\mathrm{n}}<0.7 ;[\mathrm{Ce} / \mathrm{Yb}]_{n}<1.0\right)$. The major element contents, phenocryst compositions, and REE patterns are typical of normal MORB, suggesting that these samples are comagmatic and 
correlated to three-phase crystal fractionation in a robust magma chamber. These compositions are likely the oldest for the Leg 139 suite as they represent basement further from the spreading axis.

Site 856 has primitive picritic basaltic sills, with abundant $\mathrm{Cr}$-rich spinel and forsteritic olivine. The $\mathrm{Mg} \#$ of the original magma can be deduced from the fresh spinel, which suggests magnesian compositions (Mg\# 65-70). The spinel compositions are most similar to those found in the primitive magmas on West Ridge (Van Wagoner and Leybourne, 1991). These are among the most primitive compositions reported for the Juan de Fuca Ridge. The sills crosscut the sulfide deposits at Site 856 and therefore must postdate the main phase of hydrothermal deposition. Thus, they are the youngest samples collected. The REE patterns are depleted compared to the other sites and do not have Eu anomalies, once again pointing to magmas relatively unmodified by crustal processes. The compositions are strongly LREE-depleted $\left([\mathrm{La} / \mathrm{Sm}]_{\mathrm{n}}<0.4 ;[\mathrm{Ce} / \mathrm{Yb}]_{\mathrm{n}}<0.5\right)$. The patterns are similar to those for the Heck and Heckle Seamounts (Leybourne and Van Wagoner, 1991) and for anomalous late magmas on West Ridge (Van Wagoner and Leybourne, 1991). The aluminous compositions of the spinels suggest fairly deep origin for the spinels, although this is not diagnostic. Thus these sills represent an episode of magmatism with little modification at crustal depths, postdating the existence of a robust Middle Valley magma chambers.

The sills at Site 857 are extensively modified by hydrothermal alteration, which has substantially increased the volatile, sulfur, and magnesium contents of the whole-rock compositions. Strongly zoned plagioclase could have originated through extensive in-situ differentiation or hydrothermal alteration, although the paucity of albite suggests that the former process is most important. Variable clinopyroxene compositions and the appearance of ilmenite as the dominant Fe-oxide similarly point to extensive differentiation. Some of the sills, however, also contain accumulated refractory clinopyroxene megacrysts identifiable only by the core compositions of poikilitic crystals. These are similar in composition to the megacrysts in the Site 855 basalts.

Trace elements suggest that the sills were fed by multiple magma sources with both N-MORBS and T-MORBS found within the two deep drill sites. LREE-enriched and LREE-depleted compositions alternate stratigraphically. Both positive and negative $\mathrm{Eu}$ anomalies are noted, with the former associated with abundant plagioclase phenocrysts and megacrysts in the lower portion of the hole. Most of the sills, however, have negative Eu anomalies pointing to extensive crystal fractionation of plagioclase at crustal depths. The extensive crystal fractionation, large Eu anomalies and variable compositions suggests that these sills were fed by multiple small crustal magma chambers with separate fractionation pathways.

Three sills from the top of Hole 857D and one from Hole 857C have REE patterns and phenocryst compositions almost identical to the basalts from Site 855 . These N-MORBs have the greatest depletions in LREE $\left([\mathrm{La} / \mathrm{Sm}=0.51-0.55]_{n}\right)$, flat middle to heavy REE pattern and the largest Eu anomalies pointing to crystal fractionation of plagioclase. Calcic feldspars are found with $\mathrm{Cr}$-rich spinel in one of these, suggesting the input of at least one new parental magma. These sills at Site 857 appear to have been derived from a mantle source region similar to that of Site 855 . The other sills at Site 857 show either a smaller LREE depletion, a flat REE pattern, or even a slight enrichment in LREE. The sills from Hole 857D are dominated by this second magma type with $[\mathrm{La} / \mathrm{Sm}>1]_{\mathrm{n}}$ and $[\mathrm{La} / \mathrm{Ce}]_{\mathrm{n}} \approx 1$. The other sills are intermediate in composition between these two types. This suggests that the sill complex must have been fed from at least one other mantle source besides the depleted mantle that fed the Site 855 -type magmas. Site 858 basalts are extrusives that form a constructional basement high. They are compositionally homogeneous and contain small amounts of quench plagioclase and $\mathrm{Cr}$-rich spinel with compositions suggesting $\mathrm{Mg}$ numbers for the magma ranging from $60-63$. The Site 858 basalts are characterized by $[\mathrm{La} / \mathrm{Ce}]_{\mathrm{n}}$ values $<1,[\mathrm{La} / \mathrm{Sm}]_{\mathrm{n}}$ values $>1$, and HREE depletions. The spinel composi- tions are similar to spinel in basalts from West Valley, the axial segment formed by rift propagation to west of Middle Valley, and overlap the composition found in the spinel-bearing Site 857 sill. This suggests that the Site 858 rocks are slightly enriched magmas from an axial seamount that formed during the final stages of magmatic activity in Middle Valley, feeding the sills at the adjacent Site 857. This second magma type may have mixed with the Site 855 N-MORB magma type to produce the intermediate compositions that dominate the sills in Hole 857D. The crosscutting dike found in Core 139857C-66 was apparently of this composition.

\section{CONCLUSIONS}

Igneous rocks drilled during Leg 139 span the waning stages of the Middle Valley axial magmatic activity. The diversity of magmatic types represent (1) cogenetic magmas that have undergone different degrees of differentiation; (2) magmas derived from different source regions or variable partial melting; (3) mixtures of contemporaneous magmas; and (4) magmas that were not contemporaneous. The oldest magmas are the N-MORBS from Site 855 , with chemistry and petrology typical of slow to medium spread ridges. Magmas from a similar mantle source region fed many of the sills found at Site 857, including the most altered (and presumably the oldest). These are characterized by $[\mathrm{La} / \mathrm{Ce}]_{\mathrm{n}}<0.9,[\mathrm{Ce} / \mathrm{Yb}]_{\mathrm{n}}<0.9$, and large negative Eu anomalies. A different mantle source region was tapped to produce the T-MORBs that constructed the topographic high at Site 858 . These have $[\mathrm{La} / \mathrm{Ce}]_{\mathrm{n}}$ $\approx 0.9$ and $[\mathrm{Ce} / \mathrm{Yb}]_{\mathrm{n}}>1.3$. Magmas derived from this source also fed the sills at Site 857, with evidence of mixing between this magma and an N-MORB magma like that at Site 855. Postdating the main phase of axial magmatism, sills of primitive composition were intruded at Site 856. We conclude that the Site 856 sills represent primitive, off-axis magmas, the intrusion of which postdated the existence of a crustal magma chamber and its associated hydrothermal system. Their similarity to the seamounts and the off-axis magmas on West Ridge suggests that these rocks are the youngest in Middle Valley and may be associated with the failure of the Middle Valley spreading axis, contemporaneous with or postdating the jump of ridge axis activity to the adjacent West Valley. The differing compositions of Site 855 and Site 858 reflects either differing mantle source regions or a lower degree of melting for the latter, producing the higher values of $[\mathrm{Ce} / \mathrm{Yb}]_{n}$. For the Site 857 sills the $[\mathrm{La} / \mathrm{Ce}]_{\mathrm{n}}$ is $<1$ regardless of the $[\mathrm{Ce} / \mathrm{Yb}]_{n}$, suggesting control by variable melting of a single source. Radiogenic isotopes are needed to assess this latter model (e.g., Frey et al., 1993). When the spreading jumped to West Valley, extensive crystal fractionation in small magma chambers with these mixed magmas created the highly evolved compositions in the other sills found at Site 857 . The last phase of rift failure was marked by the eruption of the highly primitive lavas at Site 856 .

\section{ACKNOWLEDGMENTS}

The authors would like to thank James Natland, Bryan Cousens, Matt Leybourne, and an anonymous reviewer for extensive reviews of an earlier version of this manuscript. This work was supported by a grant from JOI-USSAC to DSS and by the Geological Survey of Canada.

\section{REFERENCES}

Allan, J.F., 1992. Cr-spinel as a petrogenetic indicator: deducing magma composition from spinels in highly altered basalts from the Japan Sea, Sites 794 and 797. In Tamaki, K., Suyehiro, K., Allan, J., McWilliams, M., et al., Proc. ODP, Sci. Results, $127 / 128$ (Pt. 2): College Station, TX (Ocean Drilling Program), 837-847.

\footnotetext{
- Abbreviations for names of organizations and publications in ODP reference lists follow the style given in Chemical Abstracts Service Source Index (published by American Chemical Society).
} 
Allan, J.F., in press. Cr-spinel in depleted basalts from the Lau Basin backarc, ODP Leg 135: petrogenetic history from $\mathrm{Mg}$-Fe crystal-liquid exchange. In Hawkins, J., Parson, L., Allan, J., et al., Proc. ODP, Sci. Results, 135: College Station, TX (Ocean Drilling Program).

Allan, J.F., Sack, R.O., and Batiza, R., 1988. Cr-rich spinels as petrogenetic indicators: MORB-type lavas from the Lamont seamount chain, eastern Pacific. Am. Mineral., 73:741-753.

Anderson, D.J., Lindsley, D.H., and Davidson, P.M., 1993. QUILF: a PASCAL program to assess equilibria among $\mathrm{Fe}-\mathrm{Mg}$-Ti Oxides, pyroxenes, olivine and quartz. Comput. Geosci., 19:1333-1350.

Basaltic Volcanism Study Project, 1981. Basaltic Volcanism on the Terrestrial Planets: New York (Pergamon Press).

Christie, D.M., and Sinton, J.M., 1986. Evolution of abyssal lavas along propagating segments of the Galapagos spreading center. Earth. Planet. Sci. Lett., 56:321-335.

Cousens, B.L., Chase, R.L., and Shilling, J.G., 1984. Basalt geochemistry of the Explorer Ridge, northeast Pacific Ocean. Can. J. Earth Sci., 21:157170.

Davis, E.E., and Lister, C.R.B., 1977. Tectonic structures on the Juan de Fuca Ridge. Geol. Soc. Am. Bull., 88:346-363.

Davis, E.E., Mottl, M.J., Fisher, A.T., et al., 1992. Proc. ODP, Init. Repts., 139: College Station, TX (Ocean Drilling Program).

Davis, E.E., and Villinger, H., 1992. Tectonic and thermal structure of the Middle Valley sedimented rift, northern Juan de Fuca Ridge. In Davis, E.E. Mottl, M.J., Fisher, A.T., et al., Proc. ODP, Init. Repts., 139: College Station, TX (Ocean Drilling Program), 9-41.

Frey, F.A., Walker, N., Stakes, D., Hart, S.R., and Nielsen, R., 1993. Geochemical characteristics of basaltic glasses from the AMAR and FAMOUS axial valleys, Mid-Atlantic Ridge $\left(36^{\circ}-37^{\circ} \mathrm{N}\right)$ : petrogenetic implications. Earth Planet. Sci. Lett., 115:117-136.

Haggerty, S.E., 1976. Opaque oxide minerals in terrestrial igneous rocks. In Rumble, D., III (Ed.), Oxide Minerals. Mineral. Soc. Am., Short Course Notes, $\mathrm{Hg} 101-\mathrm{Hg} 170$.

Ito, E., White, W.M., and Göpel, C., 1987. The O, Sr, Nd and Pb isotope geochemistry of MORB. Chem. Geol., 62:157-176.

Karsten, J.L., Delaney, J.R., Rhodes, J.M., and Liias, A., 1990. Spatial and temporal evolution of magmatic systems beneath the Endeavour Segment, Juan de Fuca Ridge: tectonic and petrologic constraints. J. Geophys. Res., 95:19235-19256.

Klein, E.M., and Langmuir, C.H., 1987. Global correlations of ocean ridge basalt chemistry with axial depth and crustal thickness. J. Geophys. Res. 92:8089-8115.

Langmuir, C.H., Bender, J.F., Bence, A.E., and Hanson, G.N., 1977. Petrogenesis of basalts from the FAMOUS area: Mid-Atlantic Ridge. Earth Planet. Sci. Lett., 36:133-156.
Le Roex, A.P., Dick, H.J.B., Erlank, A.J., Reid, A.M., Frey, F.A., and Hart, S.R., 1983. Geochemistry, mineralogy and petrogenesis of lavas erupted along the Southwest Indian Ridge between the Bouvet Triple Junction and $11^{\circ}$ E. J. Petrol., 24:267-318.

Leybourne, M.I., and Van Wagoner, N.A., 1991. Heck and Heckle seamounts, northeast Pacific Ocean: high extrusion rates of primitive and highly depleted mid-ocean ridge basalts on off-ridge seamounts. J. Geophys. Res., 96:16275-16294.

Mathez, E.A., 1980. Sulfide relations in Hole 418A flows and sulfur contents of glasses. In Donnelly, T., Francheteau, J., Bryan, W., Robinson, P., Flower, M., Salisbury, M., et al., Init. Repts. DSDP, 51, 52, 53 (Pt. 2): Washington (U.S. Govt. Printing Office), 1069-1085.

Michael, P.J., Chase, R.L., and Allan, J.F., 1989. Petrologic and geologic variations along the Southern Explorer Ridge, northeast Pacific Ocean. J. Geophys. Res., 94:13895-13918.

Natland, J.H., 1980. Effect of axial magma chambers beneath spreading centers on the compositions of basaltic rocks. In Rosendahl, B.R. Hekinian, R., et al., Init. Repts. DSDP, 54: Washington (U.S. Govt. Printing Office), 833-850.

Natland, J.H., Adamson, A.C., Laverne, C., Melson, W.G., and O'Hearn, T. 1983. A compositionally nearly steady-state magma chamber at the Costa Rica Rift: evidence from basalt glass and mineral data, Deep Sea Drilling Project Sites 501, 504, and 505. In Cann, J.R., Langseth, M.G., Honnorez, J., Von Herzen, R.P., White, S.M., et al., Init. Repts. DSDP, 69: Washington (U.S. Govt. Printing Office), 811-858.

Papike, J.J., Cameron, K.L., and Baldwin, K., 1974. Amphiboles and pyroxenes: characterization of other than quadrilateral components and estimates of ferric iron from microprobe data. Geol. Soc. Am. Abstr. Progr., 6:1053-1054. (Abstract)

Stakes, D.S., Shervais, J.W., and Hopson, C.A., 1984. The volcanic-tectonic cycle of the FAMOUS and AMAR valleys, Mid-Atlantic Ridge $\left(36^{\circ} 47^{\prime} \mathrm{N}\right)$ : evidence from basalt glass and phenocryst compositional variations for a steady state magma chamber beneath the valley mid-sections, AMAR 3 . J. Geophys. Res., 89:6995-7028.

Van Wagoner, N.A., and Leybourne, M.I., 1991. Evidence for magma mixing and a heterogeneous mantle on the West Valley segment of the Juan de Fuca ridge. J. Geophys. Res., 96:16295-16318.

Date of initial receipt: 15 June 1993 Date of acceptance: 29 September 1993 Ms 139SR-212 